norden

\title{
Gemensam nordisk anläggningsmarknad
}

Möjligheter till en bättre fungerande nordisk marknad inom anläggningsbranschen

TemaNord 2004:551 
Gemensam nordisk anläggningsmarknad

Möjligheter till en bättre fungerande nordisk marknad inom anläggningsbranschen

TemaNord 2004:551

(C) Nordisk Ministerråd, København 2004

ISBN 92-893-1061-8

ISSN 0908-6692

Nordisk Ministerråd

Store Strandstræde 18

DK-1255 København K

Telefon (+45) 33960200

Telefax (+45) 33960202

www.norden.org

\author{
Nordisk Råd \\ Store Strandstræde 18 \\ DK-1255 København K \\ Telefon (+45) 33960400 \\ Telefax (+45) 33111870
}

Nordisk samarbete på transportområdet

Det övergripande målet för samarbetet är att främja en effektiv, konkurrenskraftig, säker, hållbar och jämställd trafik i Norden. För att inom givna resurser uppnå målet, fokuseras samarbetet primärt kring fyra områden: Hållbar mobilitet, Östersjön, Intelligenta transportsystem och Trafiksäkerhet

\section{Nordisk Ministerråd}

blev oprettet i 1971 som samarbejdsorgan mellem de nordiske landes regeringer. Ministerrådet fremlægger forslag til Nordisk Råds sessioner, viderefører rådets rekommandationer, rapporterer til Nordisk Råd om samarbejdets resultater og leder arbejdet inden for de forskellige emneområder. Samarbejdet koordineres af samarbejdsministrene, der er udpeget af det enkelte lands regering. Ministerrådet træder sammen i forskellige sammensætninger - afhængigt af hvilke spørgsmål, der skal behandles.

\section{Nordisk Råd}

blev oprettet i 1952 som et samarbejdsorgan mellem de folkevalgte forsamlinger og regeringer i Danmark, Island, Norge og Sverige. Finland indtrådte i 1955. Færøernes, Grønlands og Ålands delegationer indgår i henholdsvis Danmarks Riges og Finlands delegationer. Rådet består af 87 medlemmer. Nordisk Råd er initiativtagende og rådgivende og har kontrollerende opgaver i det nordiske samarbejde. Nordisk Råds organer er plenarforsamlingen, præsidiet og udvalgene. 


\section{Innehåll}

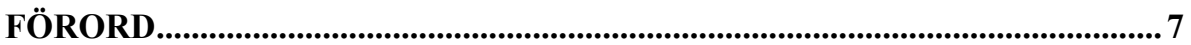

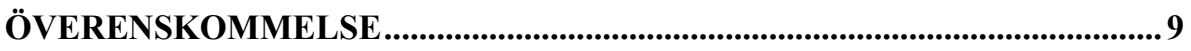

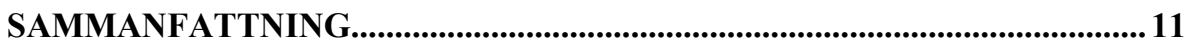

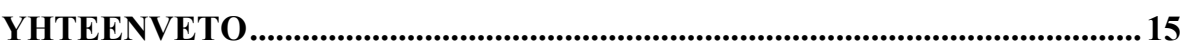

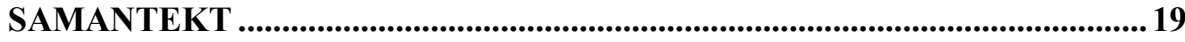

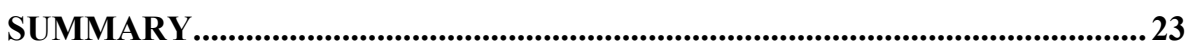

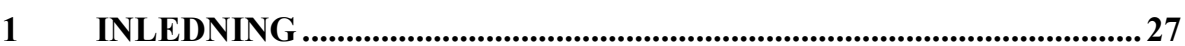

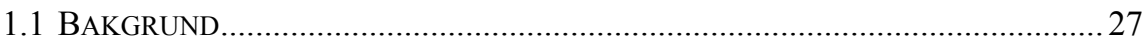

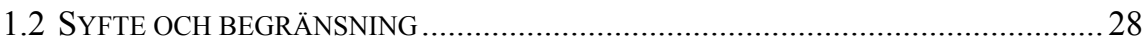

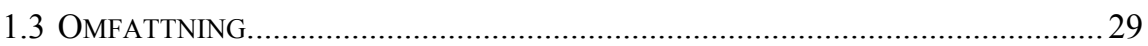

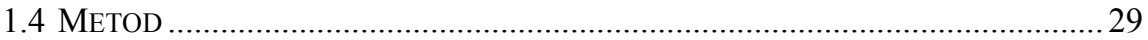

2 FRÅN OFFENTLIGT MONOPOL TILL KONKURRENS ......................33

3 AKTÖRER PÅ ANLÄGGNINGSMARKNADEN ......................................37

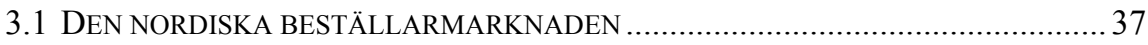

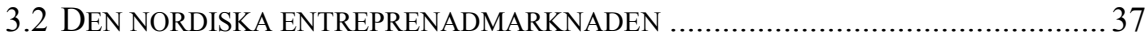

3.3 DEN NORDISKA JÄRNVÄGSENTREPRENADMARKNADEN .................................... 41

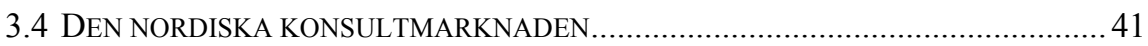

3.5 STATLIG PRODUCENTVERKSAMHET I NORDEN ................................................. 42

4 ANALYS OCH VÄRDERING AV MARKNADEN..................................49

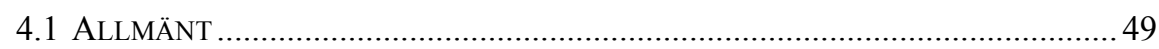

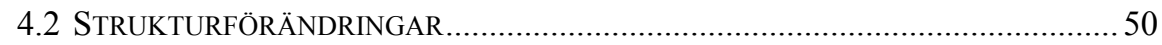

4.3 FÖRÄNDRINGAR AV STATLIGA PRODUCENTVERKSAMHETER ……….................52

4.4 INSATSVARORNAS BETYDELSE FÖR ANLÄGGNINGSMARKNADEN ......................53

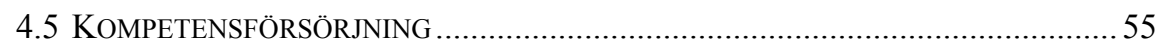

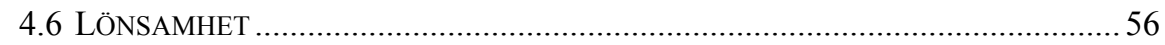

4.7 TEKNIKUTVECKLING …………………………………………………. 57

4.8 FRAMTIDA OMSÄTTNING PA ANLÄGGNINGSMARKNADEN …………………....57

5 UTVECKLINGSMÖJLIGHETER FÖR ANLÄGGNINGS-

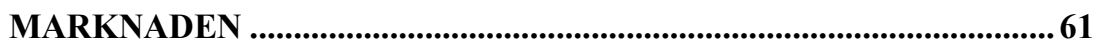

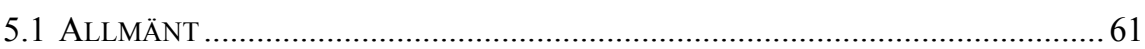

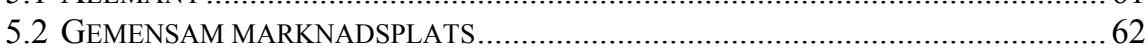

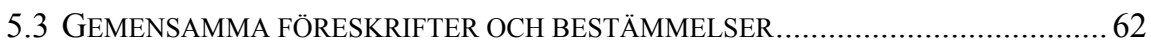

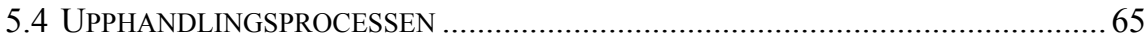


5.5 TRADITIONELLA ENTREPRENAD- OCH SAMARBETSFORMER .............................66

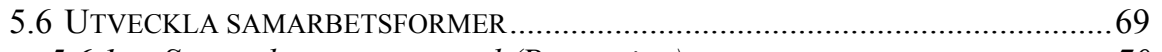

5.6.1 Samverkansentreprenad (Partnering)............................................ 70

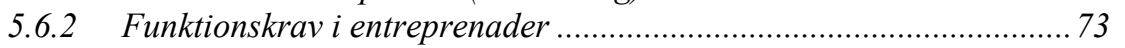

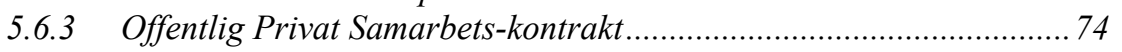

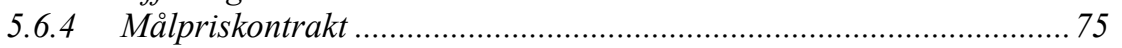

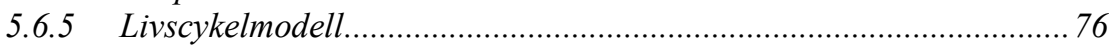

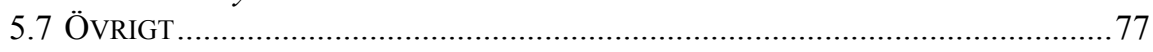

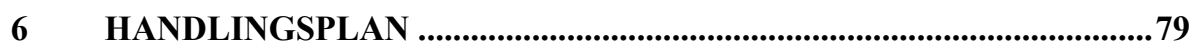

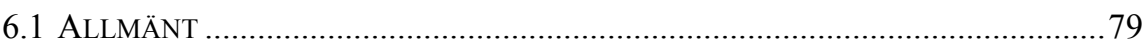

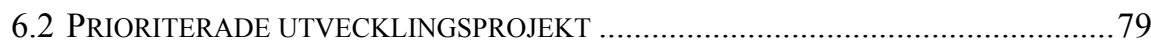

6.2.1 Gemensam marknadsplats .......................................................... 81

6.2.2 Verka för gemensamma föreskrifter och bestämmelser ..................... 81

6.2.3 Utveckling av upphandlingsprocessen......................................... 82

6.2.4 Utveckling av nya samarbetsformer .............................................. 83

6.2.5 Övriga utvecklingsmöjligheter .................................................... 83

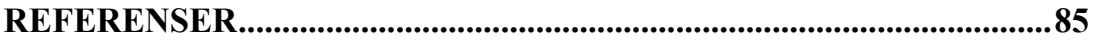

BILAGA 1 Sammanställning projektorganisation ....................................................89

BILAGA 2 Nordisk jämförelse - volymer och planeringsramar ............................93

BILAGA 3 Omsättningsöversikt - privata och statliga entreprenörer ......................97

BILAGA 4 Sammanställning - förslag på utvecklingsprojekt...................................99 


\section{Förord}

Detta projekt är finansierat med medel från Nordiska Ministerrådet. Rapporten har tagits fram av en nordisk projektgrupp efter direktiv från det svenska Näringsdepartementet i oktober 2002 med uppgiften att studera möjligheter och förutsättningar för en gemensam nordisk anläggningsmarknad inom vägoch järnvägssektorerna.

Projektet har genomförts under ledning av Vägverket i Sverige i samarbete med väg- och järnvägsmyndigheterna $i$ de nordiska länderna. Den nordiska projektgruppen har bestått av följande medlemmar:

Per Simonsen, Vejdirektoratet, Danmark Mauri Pukkila, Vägförvaltningen, Finland

Juha-Heikki Pasanen, Banförvaltningscentralen, Finland

Bjørn E Selnes, Statens vegvesen, Norge

Rolf Kr. Jelstad, Jernbaneverket, Norge

Jan Vidar Moen, Jernbanebverket, Norge

Lars Redtzer, Banverket, Sverige

Tom Ramstedt, Vägverket, Sverige

Nils-Erik Schmidt, Vägverket, Sverige

Peter Dittlau, Vägverket, Sverige

Enhetschef Tom Ramstedt har varit ordförande i projektgruppen.

Kontakten med medlemmarna i projektgruppen har skett vid möten i Helsingfors, Oslo, Köpenhamn och Stockholm samt via telefon och epost. Peter Dittlau, har varit projektledare och tillsammans med Lars Redtzer och NilsErik Schmidt ingått $i$ ett arbetande utskott som sammanställt rapporten utifrån arbetsmaterial inlämnat från respektive nation samt diskussioner i den nordiska projektgruppen.

Ett tack riktas till de entreprenörer och konsulter som har bidragit med uppgifter och material till rapporten. Avslutningsvis riktas även ett tack till alla aktörer inom anläggningssektorn i de nordiska länderna som vid seminarietillfällena i Helsingfors och Oslo visat ett stort engagemang för projektet och dess aktiviteter.

Juni 2004 


\section{Överenskommelse}

\section{Överenskommelse om genomförande av utvecklings- projekt för främjande av en gemensam nordisk anläggningsmarknad.}

\section{Bakgrund}

Under 2003 och början av 2004 har ett samarbetsprojekt genomförts mellan de nordiska länderna med det övergripande syftet att bidra till en anläggningsmarknad inom Norden med ett bättre samarbetsklimat mellan beställare och utförare än det som råder $\mathrm{i}$ dag. Avsikten har varit att på lång sikt säkra att de nordiska länderna får en väl fungerande anläggningssektor för att kunna tillgodose de krav kunderna ställer på transportsystemet.

Projektet har avgränsats till att behandla investeringar samt drift och underhåll av vägat och järnvägar.

Beslut

För att nå den önskade utvecklingen beslutas härmed att nedan angivna prioriterade utvecklingsprojekt skall genomföras.

- Gemensam databas för anslag och planer

口 Gemensam databas för ordlista

口 Gemensamma krav avseende hälsa, miljö och säkerhet (HMS) *

- Gemensamma spårtekniska och säkerhetsmässiga krav på maskiner vid järnvägsbyggande *

口 Enhetliga kompetenskrav

口 Nordisk vision avseende den framtica leverantörsmarknaden *

口 Utveckla entreprenadformer och alternativa samarbetsformer *

口 Utveckling av funktionskrav *

Projekt markerade med asterix (*) har prioriterats i samråd med verkens ledningar vid ett gemensamt möte den 16 mars 2004.

Den nordiska visionen avseende den framtida leverantörsmarknaden skall finnas framme för godkännande senast under oktober mảnad 2004 dả även övtiga projektbeskrivningar inom vetkens ansvarsområden ska vara klara. 


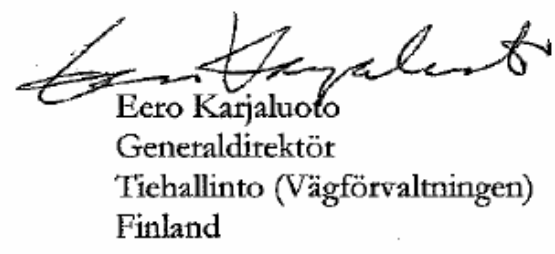

Olaw Sifklanel

Olav Søfteland

Vegdirektør

Statens vegvesen Vegdirektoratet Norge

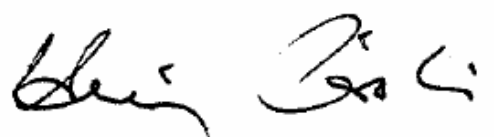

Henning Christiansen

Vejdirektør

Vejdirektoratet

Banmark

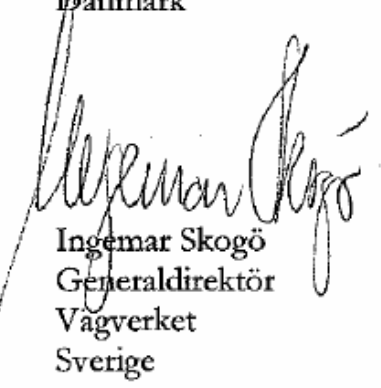

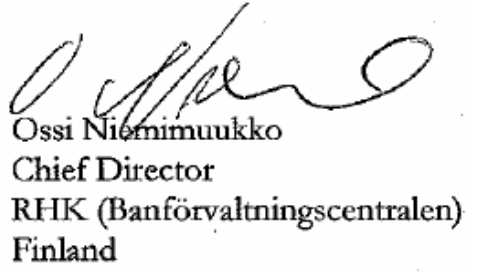

Stewivantidi

Director General

Jernbaneverket

Norge

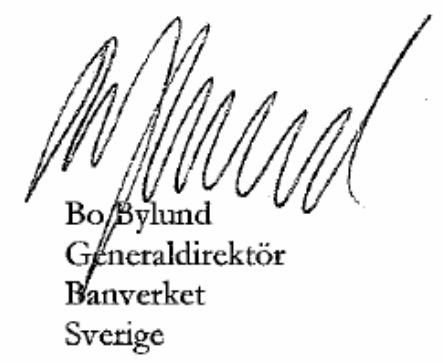

Bilaga:

Handlingsplan, daterad 2004-04-23, utdrag ur rapport "GEMENSAM NORDISK ANLÄGGNINGMARKNAD-Möjligheter till en bättre fungerande nordiske markenad inom anläggningsbranschen" 


\section{Sammanfattning}

Under 2003 och början av 2004 har ett samarbetsprojekt genomförts mellan de nordiska länderna med det övergripande syftet att bidra till en anläggningsmarknad inom Norden med ökad tillit och ökat förtroende genom ett utvecklat samarbetsklimat mellan beställare och utförare. Avsikten har varit att på lång sikt säkra att de nordiska länderna får en väl fungerande anläggningssektor för att kunna tillgodose de krav kunderna ställer på transportsystemet.

Projektet har begränsats till ett samarbete mellan departement, myndighet och statliga producentverksamheter med ansvar för investeringar samt drift och underhåll av vägar och järnvägar. Två heldagsseminarier med deltagare från såväl beställare som utförare har genomförts i Finland och i Norge.

Rapportens inledande del är en kartläggning av aktörer på dagens nordiska anläggningsmarknad och är uppdelad i beställare och utförare (entreprenörer och konsulter).

På beställarmarknaden är det de offentliga aktörerna - trafikverken och kommunerna - som är de klart största aktörerna. För att klara sina åtaganden har de behov av både traditionella anläggningsentreprenörer och entreprenörer med järnvägsteknisk inriktning.

De nordiska ländernas entreprenörer kan delas in i nivåerna nationella, regionala och lokala aktörer. I varje nordiskt land finns det mellan tre till sex stora nationella aktörer. I Finland upplever man situationen som positiv, eftersom man samtidigt har en fungerande marknad med många små lokala entreprenörer. I Danmark liksom i Norge har man en fungerande marknad med inslag av flera regionala aktörer som kan konkurrera med de stora nationella aktörerna. På den danska leverantörsmarknaden har man också inslag av internationella aktörer i en större skala än i de övriga länderna, men marknaden tenderar att få en koncentration av några få stora. I Sverige har det under de senaste årtiondena skett en strukturförändring där regionala och lokala aktörer successivt genom förvärv och fusioner mer eller mindre försvunnit från anläggningsmarknaden.

För den järnvägsspecifika ny- och ombyggnadsproduktionen är leverantörsmarknaden begränsad. Utöver de statligt ägda entreprenadföretagen som dominerar vid nyanläggning av banöverbyggnad, finns ett 10-tal järnvägstekniskt inriktade entreprenörer på den nordiska marknaden. 
Inom konsultmarknaden är trenden att utvecklingen går mot få och stora aktörer. Speciellt framträdande är detta i Sverige, där konsultmarknaden kännetecknas av några få stora nordiska och internationella aktörer.

Finland, Norge och Sverige har konkurrensutsatt nästan all eller delar av producentverksamheten inom trafikverken så att den tidigare egenregiverksamheten i olika former av affärs- och resultatenheter numer ingår som en aktör på marknaden. I Danmark sker sedan länge upphandlingen av alla anläggningsarbeten enbart från marknaden. Marknadsreformerna utvecklas dock i olika takt såväl mellan som inom de nordiska länderna.

Med utgångspunkt från den genomförda kartläggningen redovisas i rapporten en värdering och analys av den nuvarande situationen som kortfattat kan beskrivas enligt följande:

- Anläggningssektorn måste hitta arbetssätt så att alla inblandade parter finner samarbetsformer som ger förutsättningar för ett mer långsiktigt agerande än dagens system med kortsiktiga perspektiv från båda parter. De nordiska trafikverken bör se över möjligheten att aktivt skapa förutsättningar till att förändra dagens situation. Detta kan ske genom att hinder analyseras, prioriteras och i största möjliga mån elimineras och att samarbetsformerna i branschen utvecklas.

- Dagens branschstruktur kännetecknas på några av de nordiska anläggningsmarknaderna av låga anbud vilket har lett till svag produktivitets-, teknik- och produktutveckling, små forskningsinsatser, låg lönsamhet, dålig erfarenhetsåterföring, vilket i sin tur leder till kortsiktigt agerande och minskat förtroende mellan beställare och utförare. Anläggningsmarknaden måste förändras, den bör innehålla en jämn fördelning av leverantörer som kan agera både på de nordiska, nationella, regionala och lokala marknaderna.

- Sektorns kompetensförsörjningssituation är allvarlig med en hög medelålder, vilket inom de närmaste åren kommer att kräva stora nyanställningsbehov. Om dessa behov ska kunna förverkligas måste branschen finna former som intresserar unga människor - oberoende av om man är beställare eller utförare.

Efter analysfasen beskrivs i rapporten olika utvecklingsmöjligheter som kan skapa bättre förutsättningar för branschens aktörer att verka på marknaden.

För att nå den önskade marknadsutvecklingen föreslås i den avslutande delen i rapporten ett antal prioriterade utvecklingsprojekt som utgår ifrån den genomförda beskrivningen och analysen. Projekt markerade med asterix $(*)$ har prioriterats i samråd med verkens ledningar vid ett gemensamt möte den 16 mars 2004. 
Följande utvecklingsprojekt föreslås:

- Gemensam databas för anslag och planer.

- Gemensam databas för ordlista.

- Gemensamma krav avseende hälsa, miljö och säkerhet (HMS). *

- Gemensamma spårtekniska och säkerhetsmässiga krav på maskiner vid järnvägsbyggande. *

- Enhetliga kompetenskrav.

- Nordisk vision avseende den framtida leverantörsmarknaden. *

- Utveckla entreprenadformer och alternativa samarbetsformer. *

- Utveckling av funktionskrav. *

- Översyn av beskattningsregler.

- Översyn av konkurrenshämmande avtal.

För det fortsatta arbetet kommer förslag till mer detaljerade projektbeskrivningar att tas fram med ytterligare konkretisering av respektive projekts syfte och mål samt genomförandeform. 


\section{Yhteenveto}

Vuonna 2003 ja 2004 alkupuolella on pohjoismaiden kesken viety läpi yhteistyöprojekti, jonka tarkoituksena on ollut edistää luottamukseen pohjautuvia pohjoismaisia maarakennusalan markkinoita kehittämällä yhteistoimintailmapiiriä tilaajien ja toteuttajien kesken. Tarkoituksena on ollut pitkällä tähtäyksellä varmistaa, että pohjoismaihin syntyy hyvin toimiva maarakennussektori, joka kykenee täyttämään ne vaatimukset, joita asiakkaat asettavat liikennejärjestelmälle.

Projekti on rajattu yhteistyöhön niiden ministeriöiden, viranomaisten ja valtion tuotanto-organisaatioiden kesken, jotka vastaavat teiden ja rautateiden investoinneista, kunnossapidosta ja hoidosta. Projekti on pitänyt Suomessa ja Norjassa kaksi seminaaria, joissa on ollut osanottajina sekä tilaajia että toteuttajia eri pohjoismaista.

Raportin alkuosassa on kartoitus toimijoista nykyisillä pohjoismaiden maarakennusmarkkinoilla jaettuna tilaajiin ja toteuttajiin (urakoitsijat, konsultit).

Tilaajamarkkinoilla ovat julkiset toimijat - liikennevirastot ja kunnat selvästi suurimpia. Nämä tarvitsevat sekä perinteisiä maarakennusurakoitsijoita että rautatietekniikkaan suuntautuneita urakoitsijoita.

Pohjoismaissa urakoitsijat voidaan jakaa kansallisen, alueellisen ja paikallisen tason toimijoihin. Jokaisessa pohjoismaassa on kolmesta kuuteen suurta kansallista toimijaa. Suomessa tilanne koetaan kaikkiaan myönteiseksi, koska siellä on lisäksi toimivat monien pienten paikallisten toimijoiden markkinat. Tanskassa ja Norjassa on toimivat markkinat, joissa useat alueelliset toimijat kykenevät kilpailemaan suurten kansallisten toimijoiden kanssa. Tanskan toimittajamarkkinoilla on kansainvälisten toimijoiden osuus suurempi kuin muissa maissa, mutta markkinoilla on pyrkimys keskittyä joillekin harvoille suurille. Ruotsissa on viime vuosikymmeninä tapahtunut rakennemuutos, jossa alueelliset ja paikalliset toimijat ovat vähitellen yritysostojen ja fuusioiden kautta enemmän tai vähemmän hävinneet maarakennusmarkkinoilta.

Rautatieosaamista edellyttävän uus- ja perusparannustuotannon toteuttajamarkkinat ovat rajalliset. Rautateiden päällysrakenteiden uusrakentamista dominoivien valtio-omisteisten urakointiyritysten lisäksi pohjoismaisilla markkinoilla löytyy kymmenkunta rautatietekniikkaan suuntautunutta urakoitsijaa. 
Konsulttimarkkinoilla kehitystrendi on kohti harvoja ja suuria toimijoita. Erityisen voimakkaasti tämä ilmenee Ruotsissa, missä konsulttimarkkinoille on ominaista muutamat harvat pohjoismaiset ja kansainväliset toimijat.

Norja, Ruotsi ja Suomi ovat avanneet kilpailulle melkein kaiken tai osia liikennevirastojen tuotantotoiminnasta niin, että aikaisempi omajohtoinen tuotanto nykyisin erilaisten liiketoiminta- tai tulosyksiköiden muodossa on toimijana markkinoilla. Tanskassa on jo pitkään hankittu kaikki maarakennustyöt pelkästään markkinoilta. Markkinoiden uudistaminen etenee kuitenkin eri tahtiin sekä pohjoismaiden kesken että maiden sisällä eri virastojen kesken.

Tehty kartoitus lähtökohtana esitetään raportissa nykytilan arviointi ja analyysi, joka voidaan lyhyesti kuvata seuraavasti:

- Maarakennusalan on löydettävä sellainen toimintatapa, että kaikki osapuolet löytävät yhteistyömuotoja, jotka luovat edellytyksiä pitkäjänteisemmälle toiminnalle kuin nykysysteemi, jossa on lyhyt perspektiivi molemmilla puolilla. Pohjoismaisten liikennevirastojen on haettava mahdollisuuksia aktiivisesti luoda edellytyksiä nykytilan muuttumiselle. Tämä voi tapahtua analysoimalla, priorisoimalla ja mahdollisimman paljon poistamalla esteitä sekä kehittämällä alan yhteistyömuotoja.

- Osalle tämän päivän pohjoismaisista maarakennusmarkkinoista on rakenteellisesti ominaista matalat tarjoushinnat, mikä on johtanut heikkoon tuottavuuden, tekniikan ja tuotteiden kehitykseen, pieniin tutkimuspanoksiin, matalaan kannattavuuteen, huonoon kokemustenvälittämiseen, mitkä puolestaan johtavat lyhytnäköiseen toimintaan ja ovat vähentäneet luottamusta tilaajan ja toteuttajan kesken. Maarakennusmarkkinoiden on muututtava, niillä on oltava tasaisesti jakautunut toimittajakunta, joka kykenee toimimaan sekä pohjoismaisilla, kansallisilla ja alueellisilla markkinoilla että paikallisilla markkinoilla.

- Alan osaajista huolehtimisen tilanne on vakava ja ihmisten keski-ikä korkea, mikä tulee lähivuosina aiheuttamaan paljon uusrekrytointitarvetta. Jotta tämä tarve voitaisiin täyttää täytyy alalla löytää muotoja, jotka kiinnostavat nuoria ihmisiä - riippumatta siitä, ollaanko tilaajia vai toteuttajia.

Analyysivaiheen jälkeen kuvataan raportissa erilaisia kehittämismahdollisuuksia, jotka voivat luoda alan toimijoille parempia edellytyksiä markkinoilla toimimiseksi.

Halutun markkinakehityksen aikaansaamiseksi ehdotetaan raportin lappuosassa joukko priorisoituja kehittämisprojekteja, jotka pohjautuvat tehtyyn kuvaukseen ja analyysiin. Tähdellä merkityt $\left(^{*}\right)$ projektit on priorisoitu yh- 
teistyössä pohjoismaisten väylävirastojen johdon kanssa yhteisessä kokouksessa 16. maaliskuuta 2004.

Ehdotetaan seuraavia kehitysprojekteja:

- Yhteinen tietokanta määrärahoista ja suunnitelmista.

- Yhteinen tietokanta sanastolle (käsitteille).

- Yhteiset terveellisyyttä, ympäristöä ja turvallisuutta koskevat vaatimukset. *

- Yhteiset ratatekniset ja turvallisuusvaatimukset rautatienrakentamisen koneille. *

- Yhtenäiset pätevyysvaatimukset.

- Pohjoismainen visio tulevaisuuden toimittajamarkkinoista. *

- Kehitettävä urakkamuotoja ja vaihtoehtoisia yhteistyömuotoja. *

- Toimivuusvaatimusten kehittäminen. *

- Verotussäädösten tarkistus.

- Kilpailua ehkäisevien sopimusten tarkistus.

Jatkotyötä varten laaditaan ehdotukset yksityiskohtaisemmiksi projektikuvauksiksi, joissa on edelleen konkretisoitu kunkin projektin tarkoitusta, tavoitetta sekä toteutustapaa. 


\section{Samantekt}

Á árinu 2003 og í byrjun ársins 2004 hefur verið unnið samnorrænt samstarfsverkefni í peim yfirgrípandi tilgangi að stuðla að pví að skapa virkan markað á sviði mannvirkjaframkvæmda á Norðurlöndum, markað, sem njóti aukins trausts með pví að próa samvinnu milli verkkaupenda og framkvæmdaaðila. Tilgangurinn hefur verið sá, að fá fullvissu fyrir pví að Norðurlöndin hafi vel virkan markað á sviði mannvirkjaframkvæmda til langs tíma litið, svo að unnt sé að uppfylla kröfur viðskiptavinanna um flutningakerfið.

Verkefnið hefur verið takmarkað við samvinnu milli ráðuneyta, yfirvalda og ríkisstofnana, sem bera ábyrgð á framkvæmdum svo og rekstri og viðhaldi vega og járnbrauta. Tveir heilsdags umræðufundir, með pátttakendum bæði frá verkkaupum og framkvæmendum, hafa farið fram í Noregi og Finnlandi.

Fyrsti hluti skýrslunnar fjallar um könnun á pví hverjir séu virkir aðilar á norrænum markaði fyrir mannvirkjaframkvæmdir og er henni skipt upp í verkkaupa og framkvæmendur (verktaka og ráðgjafa).

Á verkkaupahliðinni eru pað fyrst og fremst opinberir aðilar - vegagerðirnar och sveitarfélögin - sem eru langstærstu aðilarnir. Til pess að geta sinnt hlutverkum sínum hafa peir pörf fyrir að hafa aðgang að hefðbundnum byggingaverktökum svo og verktökum á sviði járnbrautartækni.

Verktökum á Norðurlöndum má skipta upp í framkvæmendur á lands-, landshluta- og staðarvísu. Í hverju Norðurlandanna um sig eru prjú til sex stór fyrirtæki, sem hafa starfsemi um allt landið. Í Finnlandi finnst mönnum ástandið vera jákvætt, par eð pað er samtímis virkur markaður fyrir mörg lítil staðbundin verktakafyrirtæki. Í Danmörku og eins í Noregi er virkur markaður með ívafi af mörgum svæðisverktökum sem geta keppt við stóru landsfyrirtækin. Á danska markaðinum fyrir verksala er allnokkuð um alpjóðafyrirtæki, og pað í öllu stærra mæli en í hinum löndunum, og er tilhneigingin í pá átt, að fáein stór fyrirtæki lifa af samkeppnina. Í Svípjóð hefur átt sér stað umbreyting á síðustu áratugum í pá átt, að svæðis- og staðbundin verktakafyrirtæki hafa smám saman verið keypt upp og par með horfið af byggingaframkvæmdamarkaðnum.

Á pví sviði járnbrautarframkvæmda sem varðar nýlagnir og viðhaldsframkvæmdir er markaðurinn fyrir framkvæmendur takmarkaður. Umfram pau verktakafyrirtæki sem eru í ríkiseign, og eru allsráðandi hvað snertir 
nýlagnir á járnbrautum, starfar um pað bil tugur verktaka á sviði járnbrautartækni á norræna markaðnum.

Á ráðgjafafyrirtækjasviðinu er próunin í áttina að færri og stærri aðilum. Sérstaklega áberandi kemur petta fram í Svíbjóð, par sem fáein stór norræn og alpjóðleg fyrirtæki eru allsráðandi á ráðgjafamarkaðnum.

Í Finnlandi, Noregi og Svípjóð er næstum öll framleiðsla á vegum vegastofnana háð samkeppni, pannig að sú starfsemi, sem áđur var rekin á peirra eigin vegum, en skipt upp á mismunandi viðskipta- og rekstrareiningar, er nú rekin sem markaðsaðili. Í Danmörku hafa öll framkvæmdaverkefni eingöngu verið keypt á almennum markaði. Markaðsvæðingin hefur pó próast 1 mismunandi mæli bæði milli og innan Norðurlandanna.

Með viðmiðun af peirri kortlagningu, sem hefur verið gerð, er í skýrslunni mat og greining á núverandi ástandi, sem í stuttu máli má lýsa á eftirfrandi hátt.

- Á mannvirkjageiranum verður að finna vinnumáta, pannig að allir aðilar, sem málið snertir, geti fundið samstarfsform, sem geti skapað betri forsendur fyrir starfsemi til langs tíma í stað pess að allar viðmiðanir, af beggja hálfu, séu gerðar til stutts tíma. Norrænum samgöngumálastofnunum ber að nota tækifærið til pess að, á virkari hátt en áður, skapa forsendur fyrir pví að breyta ríkjandi ástandi. Petta má gera með pví að greina hindranir, forgangsröðun og afnámi peirra í eins ríkum mæli og unnt er og eins að samvinnuform á geiranum próist.

- $\quad$ bað sem er táknrænt fyrir uppbyggingu geirans á nokkrum mörkuðum norrænna mannvirkjaframkvæmda nú, eru lág tilboð, sem hafa haft í för með sér litla framleiðni-, tækni- og vörubróun, litla rannsóknarstarfsemi, lélega afkomu og litla reynslunýtingu, sem einnig hefur haft í för með sér að skammtíma sjónarmið verða ríkjandi og minni trúnaður milli verkkaupa og verksala. Mannvirkjaframkvæmdageirinn verður að taka breytingum, pað verður að vera fyrir hendi jöfn dreifing á verkseljendum, sem geta unnið jöfnum höndum bæði á norrænum, pjóðlegum, landshluta- og svæðismarkaði.

- Ástandið innan geirans er alvarlegt, hvað snertir hæfnisendurnýjun, par eð meðalaldurinn er hár og mikil pörf verður fyrir nýráđningar á næstu árum. Til pess að unnt verði að uppfylla pessar parfir, verður geirinn að finna form, sem geta laðað til sín ungt fólk - óháð pví hvort heldur um er að ræða verkkaupa eða verksala.

Að lokinni greiningu er nokkrum hugsanlegun próunarmöguleikum lýst sem gætu skapað betri forsendur möguleika aðstöðu fyrir framkvæmendur til pess að verða virkari á markaðinum. 
Í peim tilgangi að geta uppfyllt óskir um markaðspróun eru gerðar tillögur í lok skýrslunnar um nokkur forgangsverkefni par sem gengið er út frá peirri lýsingu og greiningu sem gerð hefur verið. Verkefni sem merkt eru með stjörnu (*) hafa verið gerð að forgangsverkefnum í samráði við stjórnendur viðkomandi stofnana á sameiginlegum fundi pann 16. marz 2004.

Lagt er til að unnið verði við eftirtalin próunarverkefni:

- Sameiginlegur gagnagrunnur fyrir fjármagn og áætlanir.

- Sameiginlegur gagnagrunnur með orðalista.

- Sameiginlegar kröfur, sem varða heilsu-, umhverfis- og öryggismál (HUÖ).

- Sameiginlegar kröfur sem snerta sportækni og öryggismál varðandi vélar sem unnið er með við járnbrautarlagningar. *

- Sameiginlegar hæfniskröfur.

- Norræn sýn varðandi verksölumarkaðinn í framtíðinni.

- Próun á nýjum formum á verksölu og marghátta samvinnuformum. *

- Próun á kröfum, sem snerta virkni. *

- Endurskoðun á skattareglum.

- Endurskoðun á samningum, sem virka letjandi á samkeppni.

Hvað varðar áframhaldandi starf verða gerðar tillögur um nánari verklýsingar til pess að fá fram meira ápreifandi tillögur um takmark og markmið hvers verkefnis fyrir sig, svo og hvernig pað skuli framkvæmt. 


\section{Summary}

During 2003 and the beginning of 2004, a co-operation project has been conducted between the Nordic countries with the overall aim of contributing towards a construction market in the Nordic area that inspires a greater level of trust and confidence through a developed climate of co-operation between employer and producer. The intention has been in the long term to ensure that the Nordic countries acquire a well-functioning construction sector in order to be able to meet the requirements that clients make on the transport system.

The project has been limited to co-operation between departments, authorities and government production units with responsibility for investments and for the operation and maintenance of roads and railways. Two full-day seminars have been held in Norway and Finland with participants from both the employer and the producer sides.

The introductory section of the report comprises an inventory of players on today's Nordic construction market, and is divided into employers and producers (contractors and consultants).

On the employers' market, it is the public sector players - transport authorities and municipalities - who are the largest stakeholder group. In order to be able to meet their obligations, they require the services of both traditional construction contractors as well as contractors with a focus on railway engineering.

The contractors in the Nordic countries can be divided into national, regional and local players. In each Nordic country there are between three and six large national companies. In Finland, the situation is experienced as being positive, since there is at the same time a well-functioning market with a large number of small local contractors. In Denmark, as in Norway, there is a well-functioning market with several regional players who can compete with the major national players. On the Danish supplier market, there are also international players on a greater scale than in the other countries, but the market is becoming dominated by one or two major companies. In Sweden, there has been a structural change in recent decades whereby regional and local players have gradually more or less disappeared from the construction market as a result of acquisitions and mergers. 
For the specific railway-oriented market for new construction and conversion works, the number of suppliers is limited. Apart from the state-owned contracting companies that have a dominant position as regards the construction of new superstructure, there are some 10 contractors with a focus on railway engineering on the Nordic market.

Within the consulting market, the trend is towards fewer and larger players. This is particularly apparent in the case of Sweden, where the consultancy market is characterised by a limited number of large Nordic and international companies.

Finland, Norway and Sweden have subjected almost all or parts of the producer operations within their respective transport administrations to competition so that the functions which previously carried out work under their own management in various forms of business units and profit centres now compete as players on the market. In Denmark, the procurement of all construction works has for many years only been effected from the market. However, the market reforms are progressing at different rates both between and within the Nordic countries.

With the completed inventory as a basic starting point, an assessment and analysis are made in the report of the current situation, which can be briefly described as follows:

- The construction sector must develop an approach whereby all the parties involved find forms of co-operation that provide the potential that is necessary for a more long-term way of working that than today's system with a short-term perspective from both parties. The Nordic transport administrations should review the possibilities of actively creating the conditions needed in order to change the present situation. This can be done by analysing, prioritising and as far as possible eliminating obstacles so that forms of co-operation are developed within the sector.

- Today's sectoral structure is characterised on several of the Nordic construction markets by low tenders, which has resulted in a low level of productivity, technical and product development, limited research work, a low level of profitability and poor feedback of experience. This has in turn led to a short-term approach and less trust between employer and producer. The construction market must be changed. It should be characterised by an even distribution of suppliers who can work on all markets, irrespective of whether they are Nordic, national, regional or local.

- The situation within the sector as regards competence provision is serious with a high average age, which over the next few years will demand major recruitment efforts. If it is to be possible to meet these demands, 
the sector must be able to find forms that are of interest to young people - irrespective of whether the recruitment is to the employer side or the producer side.

After the analysis phase, the report describes various development possibilities that can create better conditions for the players in the sector to act on the market.

In order to achieve the required market development, the final part of the report proposes a number of high-priority development projects that are based on the descriptions and analyses that have been carried out. Those projects marked with an asterix $\left(^{*}\right)$ have been given priority in consultation with the managements of the different transport administrations at a joint meeting held on 16 March 2004.

The following development projects are proposed:

- A common database for appropriations and plans.

- A common database for wordlists.

- Common requirements for health, environment and safety (HMS). *

- Common railway engineering and safety requirements for machinery used in railway construction.

- Uniform competence requirements.

- A Nordic vision for the future supplier market. *

- The development of contract forms and alternative forms of cooperation.

- Development of functional requirements. *

- Review of tax regulations.

- Review of agreements that hamper competition.

For the purpose of continued work, proposals for more detailed project descriptions will be drawn up together with more details on the purpose and goals of the projects and their form of implementation. 


\section{Inledning}

\section{Bakgrund}

I Norden finns en stark marknadskoncentration inom anläggningssektorn med få aktörer vilket leder till en begränsad konkurrens med höga anläggningskostnader som följd. Förtroendet för anläggningssektorn har under det senaste årtiondet dessutom minskat $\mathrm{i}$ omvärlden då branschen ertappats med dels kartellverksamhet i syfte att undanröja konkurrens och dels kvalitetsbrister i utförda anläggningar.

Rörligheten på anläggningsmarknaden i Norden är idag begränsad. De största entreprenörerna har i regel bolagiserat verksamheten i respektive land. De medelstora bolagen försöker i mindre omfattning röra sig över gränserna. För att en etablering i ett nytt land skall kunna ske smidigt är det mer eller mindre en förutsättning att företaget samverkar med någon lokal aktör eller köper upp en mindre aktör på den nya marknaden. Järnvägsentreprenörerna agerar i stort sett på samma sätt som de traditionella anläggningsentreprenörerna med den skillnaden att de stora aktörerna är statligt ägda företag som rör sig i begränsad omfattning över gränserna.

Ryckigheten i anslagsnivåerna medför att leverantörerna får svårigheter att bedöma behovet av resurser och genomföra nödvändiga investeringar. Vid anslagsförändringar måste branschen snabbt anpassa resurser, kompetens och maskiner. Dessa snabba volymväxlingar medför högre kostnader och kan leda till kvalitetsbrister vilket branschen och samhället får lida av. Därutöver medför ryckigheten i finansieringen av samhällsekonomiskt lönsamma projekt att investeringarna kommer samhället till del senare.

En många gånger dålig dialog och dåligt samarbete mellan aktörerna har $\mathrm{i}$ Sverige givit upphandlingar med pressade priser, stora osäkerheter, ensidigt risktagande och korta genomförandetider vilket $i$ sin tur resulterat $i$ att egna kortsiktiga mål prioriteras framför långsiktiga samhällsekonomiska lösningar. Samarbetet mellan beställare och utförare borde istället inriktas mot ett långsiktigt perspektiv där samhällets och användarnas mål sätts mer $\mathrm{i}$ fokus än vad som sker idag. Sverige, Norge och Finland har dessutom konkurrensutsatt nästan all producentverksamhet inom trafikverken vilket ställer nya krav på såväl trafikverken som beställare och egna eller externa utföraraktörer. I Danmark sker upphandlingen av anläggningsarbeten enbart från marknaden. 
En viktig faktor för att öka anläggningssektorns effektivitet är att en sund konkurrens råder på en marknad med tillräckligt många aktörer. En väl fungerande anläggningssektor är nödvändig för Norden för att kunna tillgodose de krav som kunderna ställer på transportsystemet.

\subsection{Syfte och begränsning}

Sverige var under år 2003 ordförande för det nordiska regeringssamarbetet. Temat för det svenska ordförandeskapet var "Integration Norden". Det svenska ordförandeprogrammet tog upp fyra olika aspekter av begreppet integration inom de nordiska länderna; integrationen mellan de nordiska länderna, integrationen mellan Norden och närområdet och integration i det europeiska samarbetet. Inom ramen för integrationen mellan de nordiska länderna driver Sverige genom Nordiska ministerrådet ett samarbetsprojekt med det övergripande syftet att bidra till en anläggningsmarknad inom Norden med ett bättre samarbetsklimat mellan beställare och utförare. Avsikten är att på lång sikt säkra att de nordiska länderna får en väl fungerande anläggningssektor för att kunna tillgodose de krav kunderna ställer på transportsystemet. Projektet studerar möjligheterna och förutsättningarna för en gemensam nordisk marknad för anläggningstjänster inom väg- och järnvägssektorn.

Projektet innehåller följande delar:

- Kartläggning av den nordiska anläggningsmarknaden

- Utvärdering av fördelar, nackdelar och förbättringsåtgärder med upphandlingsprocessen i respektive nordiskt land med fokus på upphandlingsunderlag, entreprenadformer och samarbetsformer

- Ökad kompetens och ökade samarbetsmöjligheter mellan de nordiska länderna

- Förslag på fortsatt arbete

Projektet begränsas till samarbete mellan departement, myndigheter och producentverksamhet för investeringar samt drift och underhåll av vägar och järnvägar.

I rapporten definieras begreppet "Produktion" som genomförandet av den av beställaren upphandlade planeringen, projekteringen, byggandet, underhållet eller driften av ett anläggningsprojekt och kan avse såväl ett enskilt objekt som åtgärder på ett väg- eller järnvägsnät. 


\subsection{Omfattning}

Projektet är indelat i tre aktiviteter;

Aktivitet 1 - kartläggning av anläggningsmarknaden.

- Projektets första del fokuserar på en kartläggning av den nordiska anläggningsmarknaden. Den redovisar vilka företag som är aktiva inom de olika länderna. Kartläggningen omfattar även en bedömning av anläggningsmarknadens storlek i Norden under de närmaste 10 åren. Dessutom utförs en analys av insatsvarornas betydelse. Kartläggningen avslutas med en beskrivning av de statliga producentverksamheterna och vilken roll de har på anläggningsmarknaden.

Aktivitet 2 - ökad konkurrens och nya samarbetsformer.

- Mot bakgrund av den beskrivna kartläggningen genomförs i andra delen en analys av vilka hinder och möjligheter som finns för att få en bättre fungerande entreprenadmarknad genom ett "VinnaVinna"-system med ett livstidsperspektiv i stället för dagens system med entreprenadupphandlingar med kortsiktiga perspektiv från båda parter och till en lägsta kostnad. En viktig del av analysen är vad förbättrade samarbetsformer mellan beställar- och utförarorganisationer skulle innebära för samhället, användarna och aktörerna på leverantörsmarknaden. En annan del i arbetet är att analysera hinder och möjligheter för ökad konkurrens.

Aktivitet 3 - handlingsplan.

- Den tredje delen fokuserar på hur beställar-/utförarrollerna kan utvecklas, och beskrivs i en gemensam handlingsplan.

Inom projektet har även ett erfarenhetsutbyte skett mellan ansvariga departement/ministerier, trafikverkens beställarorganisationer och statliga producentverksamheter. Erfarenhetsutbyte har skett dels i de grupper som bildats mellan departement, trafikverk och statliga producentverksamheter och dels genom några seminarier där resultaten från genomförda studier presenterats och där även övriga aktörer på marknaden har deltagit.

\subsection{Metod}

Nationella arbetsgrupper med representanter från beställarorganisationerna vid trafikverken och statliga producentverksamheterna har arbetat med de olika aktiviteterna. Det har dock förekommit olika utformningar på dessa arbetsgrupper. I en del länder har utförarsidan även varit representerade av andra entreprenörer än statliga producenter. Andra har integrerat väg- och bansektorn i en gemensam arbetsgrupp. Representanter från Vägverket re- 
spektive Banverket i Sverige har haft ett samordningsansvar för respektive trafikområde. Island och Färöarna och har endast haft rollen som observatörer, dvs. de har tagit del av det framtagna materialet. Banedanmark i Danmark har erbjudits, men ej deltagit i projektet varför underlag avseende den danska banhållningen inhämtats på annat sätt.

I figur 1.1 presenteras en översiktlig schematisk skiss över projektorganisationen, dess arbetssätt och ansvar.

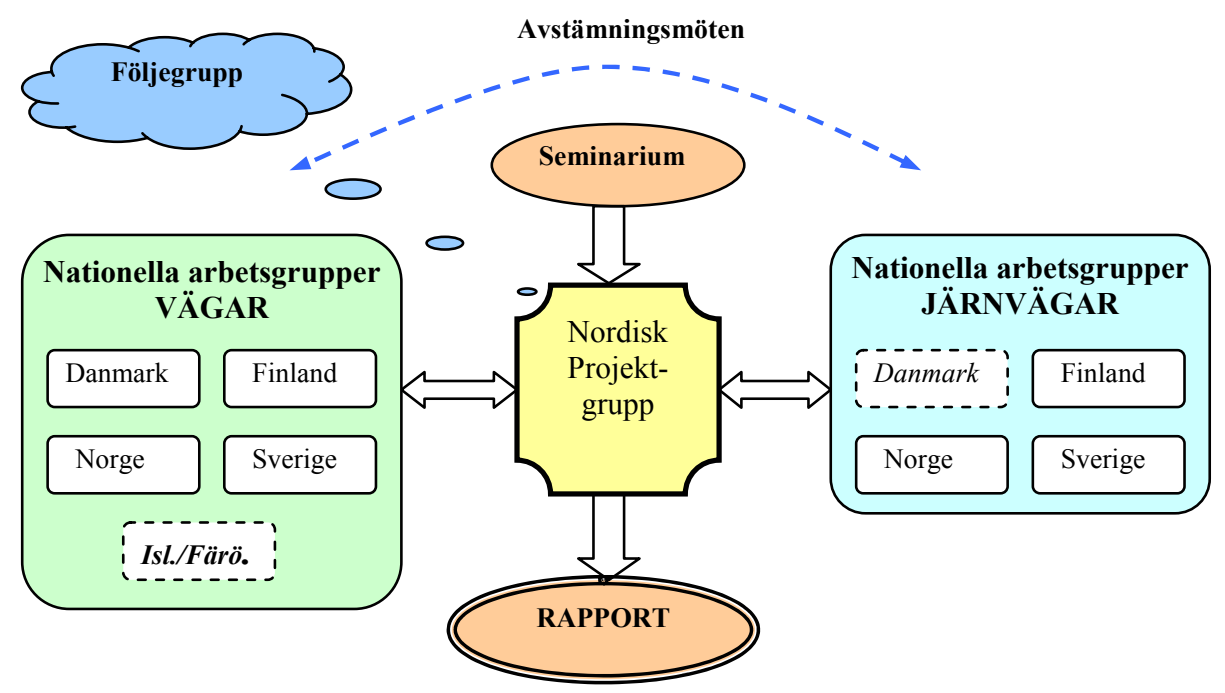

Figur 1.1 Schematiska skiss över projektorganisation.

Den nordiska projektgruppen, bestående av ca tio personer från beställarorganisationerna vid trafikverken i de nordiska länderna, har kritiskt granskat och diskuterat de nationella arbetsgruppernas arbete. I den nordiska projektgruppen har även ingått ett arbetande utskott, vilket haft till uppgift att sammanställa material och synpunkter som framkommit i de nationella arbetsgrupperna och vid seminarierna. Utskottet har tillsammans med den nordiska projektgruppen sammanställt denna slutrapport med beskrivning av genomförda insatser och uppnådda resultat.

Under projektets gång har två seminarier genomförts för att få in synpunkter från branschen på framarbetat förslag. En avslutande slutrapportering av projektet har presenterats för de nordiska generaldirektörerna från väg- respektive banverken. På detta sätt fick trafikverken del av resultaten och fick också möjlighet att framföra synpunkter på inriktningen på en framtida handlingsplan. 
Representanter från ansvariga departement för väg- och järnvägsinfrastruktur inom de nordiska länderna har fungerat som projektets följegrupp.

I bilaga 1 redovisas namn på de personer som ingått i de olika nationella arbetsgrupperna, den nordiska projektgruppen, det gemensamma arbetsutskottet och följegruppen. 


\section{Från offentligt monopol till konkurrens}

Förändrade former för planering, styrning och genomförande av verksamheter inom den offentliga sektorn har varit intensiv i Norden och Europa under hela 1990-talet. Det politiska syftet med reformerna har varit att öka den offentliga sektorns effektivitet och skapa bättre anpassning till brukarnas behov och önskemål. Förändringen har skett genom att offentliga monopol gjorts om till konkurrensutsatta företag som drivits efter marknadsekonomiska förutsättningar. De tillämpade principerna kallas "New Public Management" och kännetecknas av inriktningsmålen:

- Ökad ekonomisk effektivitet

- Effektivisering av offentlig förvaltning

- Marknadsekonomiska förutsättningar

- Konkurrensutsättning

- Avbyråkratisering

Nedan redovisas och kommenteras en teoretisk bild över olika faser i en vägeller banorganisations utveckling. Bilden innebär inte att den slutliga lösningen alltid är en privatiserad verksamhet utan kan beroende på vilka förutsättningar som gäller pendla fram och tillbaka mellan de olika faserna. Inom järnvägsområdet $\mathrm{i}$ England har man t.ex. valt att gå ifrån en helt privatiserad verksamhet tillbaka mot en mer förvaltningsliknande form. 


\section{Organisationsreformer inom väg- och banhållning}

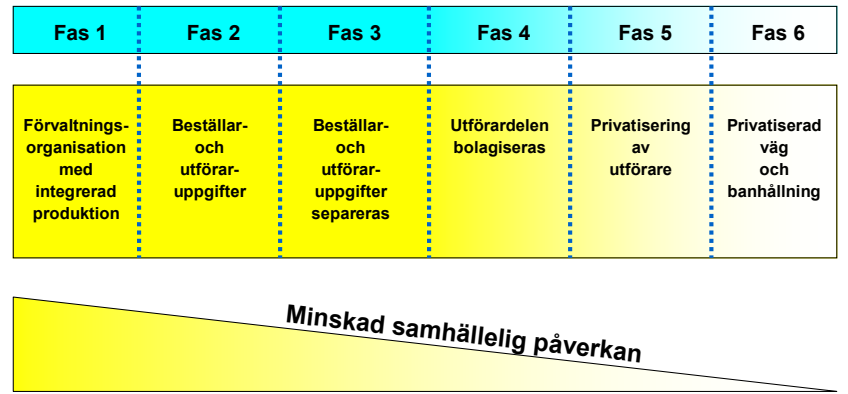

\section{Figur 2.1 Faser i väg- och banorganisationers utveckling (Världsbanken).}

Fas 1: Förvaltningsorganisation med integrerad produktion

Det allmänna ansvarar för all planering och produktion av samtliga väg- och banhållningsåtgärder och genomförandet sker med egna produktionsresurser.

Fas 2: Beställar- och utföraruppgifter

Olika ansvarsroller har klarlagts och delats upp på beställaruppgifter och utföraruppgifter.

Fas 3: Beställar- och utföraruppgifter separeras

Ansvarsrollerna inom väg- och banhållarorganisationerna separeras. Beställarna fokuserar på prioritering, planering, finansiering och beställning av den verksamhet som ska genomföras och utförarna på ett så effektivt genomförande som möjligt.

Fas 4: Utförardelen bolagiseras

Utförardelen skiljs från beställardelen och organiseras som bolag ägt av det allmänna.

Fas 5: Privatisering av utförarorganisationen

Utförarorganisationen privatiseras och beställardelen organiseras som ett bolag ägt av det allmänna.

Fas 6: Privatiserad väg-, gatu- och banhållning 
Det offentliga - stat, kommun eller motsvarande - har inte längre någon inblandning i väg- och gatuhållningen utan den sköts såväl beställnings- som genomförandemässigt av privata intressenter.

Nya Zeeland och England har drivit denna inriktning långt och principerna tillämpas också alltmer inom många EU-länder t.ex. Frankrike, Belgien och Tyskland. I övriga delar av världen tillämpas principerna också i Kanada, USA och Sydamerika.

Den s.k. beställar-/utförarmodellen är ett resultat av denna inriktning och skapar en renodling av de tre rollerna - beställare, utförare och kund. En vanlig beskrivning av beställarrollen är att det är den aktör som står för samhällets intressen men kan också vara den som bygger upp och ser till att marknader fungerar. Utföraren är den som genom avtal med beställaren producerar den beställda verksamheten. Med kund avses i allmänhet den som utnyttjar en viss service.

Statsmakterna i de nordiska länderna har som huvudprincip att staten inte ska bedriva verksamhet på marknader där tjänster och varor kan erbjudas med fungerande konkurrens. Det är dock ovanligt att hela verksamheten inom en myndighet är konkurrensutsatt så att andra producenter tillhandahåller alla myndighetens varor och tjänster. Större eller mindre delar av vissa myndigheter - t.ex. verk med anslags- eller avgiftsfinansierad verksamhet har i varierande omfattning verksamhet som är konkurrensutsatt.

Finland, Norge och Sverige har konkurrensutsatt all eller delar av produktionsverksamheten inom trafikverken så att den tidigare egenregiverksamheten i olika former av affärs- och resultatenheter ingår som en aktör på marknaden. I Danmark sker sedan länge upphandlingen av alla anläggningsarbeten enbart från marknaden. Marknadsreformerna utvecklas dock i olika takt såväl mellan som inom de nordiska länderna.

I tabell 2.1 redovisas en sammanställning över olika former som använts för konkurrensutsättning av väg-, gatu- och banhållningen i Danmark, Finland, Norge och Sverige. 
Tabell 2.1 Former för konkurrensutsättning av väg-, gatu- och banhållningen i Norden (NVF Utskott 41 samt Banverket).

\begin{tabular}{|c|c|c|c|c|}
\hline Sektor & Danmark & Finland & Norge & Sverige \\
\hline Stat & $\begin{array}{c}\text { Väg: } \\
100 \% \\
\text { konkurrensutsatt. } \\
\text { Staten har inte } \\
\text { någon egen pro- } \\
\text { duktions- } \\
\text { verksamhet. } \\
\text { Järnväg: } \\
\text { Investerings- } \\
\text { verksamheten } \\
\text { upphandlas till } \\
\text { 100\% i konkurrens. } \\
\text { Drift- och under- } \\
\text { hålls-verksamheten } \\
\text { upphandlas succes- } \\
\text { sivt i konkurrens. }\end{array}$ & $\begin{array}{l}\text { Väg: } \\
\text { Produktions- } \\
\text { verksamheten i ett } \\
\text { Vägaffärsverk från } \\
\text { 2001. } \\
100 \text { \% konkurrens- } \\
\text { utsättning } \\
\text { från } 2005 . \\
\text { Järnväg: } \\
\text { Produktions- } \\
\text { verksamheten i } \\
\text { statligt ägt bolag. } \\
\text { Investerings- } \\
\text { verksamheten } \\
\text { upphandlas till } \\
\text { 100\% i konkurrens. } \\
\text { Drift- och under- } \\
\text { hållsverksam-heten } \\
\text { upphandlas ej i } \\
\text { konkurrens. }\end{array}$ & $\begin{array}{c}\text { Väg: } \\
\text { Vegvesenet uppde- } \\
\text { lat i en myndig- } \\
\text { hetsdel och en } \\
\text { produktions-del } \\
1995 . \\
\text { Produktionsdelen } \\
\text { eget bolag från } \\
2003 \text {. } \\
100 \% \text { konkurrens- } \\
\text { utsättning från } \\
2003 \text {. } \\
\text { Järnväg: } \\
\text { Drift- och mindre } \\
\text { underhålls- } \\
\text { verksamhet utförs i } \\
\text { egenregi i förval- } \\
\text { tar-organisationen. } \\
\text { Större underhåll } \\
\text { och investerings- } \\
\text { verksamheten } \\
\text { upphandlas till } \\
100 \% \text { i konkurrens. }\end{array}$ & $\begin{array}{l}\text { Väg: } \\
\text { Vägverket uppdelat } \\
\text { i en väghållardel } \\
\text { och en produk- } \\
\text { tionsdel från } 1992 . \\
100 \% \text { konkurren- } \\
\text { sut-sättning från } \\
1999 . \\
\text { Järnväg: } \\
\text { Prod.verksamhet i } \\
\text { separat enhet inom } \\
\text { Banverket. } \\
\text { Inv.verksamhet } \\
\text { upphandlas till } \\
\text { 100\% i konkurrens. } \\
\text { Drift- och under- } \\
\text { hållsverksam-het } \\
\text { upphandlas succes- } \\
\text { sivt i konkurrens. }\end{array}$ \\
\hline $\begin{array}{l}\text { Amt/- } \\
\text { fylke }\end{array}$ & $\begin{array}{l}\text { Flera modeller } \\
\text { används. } \\
\text { Några amt har egna } \\
\text { produktionsenhe- } \\
\text { ter. }\end{array}$ & - & $\begin{array}{l}\text { Staten har allt } \\
\text { ansvar för kon- } \\
\text { traktsarbeten för } \\
\text { fylkesvägar, men } \\
\text { finansiering sker } \\
\text { från fylket. }\end{array}$ & - \\
\hline $\begin{array}{c}\text { Kommu- } \\
\text { ner }\end{array}$ & $\begin{array}{l}\text { Ungefär hälften av } \\
\text { kommunerna } \\
\text { anbudsprövar delar } \\
\text { av verksamheten. } \\
\text { Många kommuner } \\
\text { har egna produk- } \\
\text { tionsenheter. }\end{array}$ & $\begin{array}{l}70 \% \text { av inves- } \\
\text { teringsvolymerna } \\
\text { konkurrensutsatt } \\
\text { Egna produktions- } \\
\text { enheter, kommuna- } \\
\text { la affärsverk } \\
\text { Driftverksamheten } \\
\text { konkurrensutsatt } \\
\text { till } 15 \% \text { och } \\
\text { kommer att öka till } \\
\text { mellan } 30 \text { och } 35 \\
\% 2012\end{array}$ & $\begin{array}{l}\text { Flera olika model- } \\
\text { ler: } \\
\text { Bolag i Oslo. } \\
\text { Interna produk- } \\
\text { tionsenheter. } \\
\text { Samlade driftav- } \\
\text { delningar. }\end{array}$ & $\begin{array}{l}\text { Flera olika model- } \\
\text { ler: } \\
\text { Bolag, kommunala } \\
\text { bolag, egna pro- } \\
\text { duktionsenheter. }\end{array}$ \\
\hline
\end{tabular}




\section{Aktörer på anläggningsmarknaden}

\subsection{Den nordiska beställarmarknaden}

Den nordiska beställarmarknaden kan delas in i offentliga och privata beställare. De offentliga beställarna är främst trafikverken och kommunerna.

Beställaren är den som beslutar om investeringar, ansvarar för att anläggningen svarar mot gällande författningar, att finansiering ordnas, att kunderna blir nöjda och att investeringarna blir samhällsekonomiskt lönsamma. Beställaren svarar också för att samhällets olika krav på anläggningen tillgodoses.

I bilaga 2 redovisas de nordiska ländernas finansieringsvolymer. Jämförelsen innefattar uppgifter om areal, befolkning, allmänna vägar samt medelsvolymer för investeringar, drift och underhåll i väg- och järnvägstransportsystemen.

För att klara sina åtaganden har trafikverken behov av både traditionella anläggningsentreprenörer för byggande, drift och underhåll av väg- och banunderbyggnad och entreprenörer med järnvägsteknisk inriktning för byggande och underhåll av de mer järnvägsspecifika anläggningarna. Även inom vägsektorn finns ett stigande behov av specialistkompetens hos entreprenörer, exempelvis finns ett utökande behov av kompetenser inom elektronik, kommunikation, övervakning och styrning. Dessutom finns stort behov av olika typer av konsulttjänster.

Nedan följer en kartläggning av dagens nordiska anläggningsmarknad. Kartläggningen omfattar både entreprenör- och konsultmarknaden.

\subsection{Den nordiska entreprenadmarknaden}

Den nordiska entreprenadmarknaden kan delas in i nivåerna nationella, regionala och lokala aktörer.

Nationella aktörer är företag som ofta har verksamhet inom både bygg- och anläggningsmarknaden och ibland även industriproduktion. Aktörerna är ofta nordiska eller internationella och är finansiellt mycket starka, vilket möjliggör kompetensuppbyggnad, uppköp och strategisk anbudsgivning. Många av företagen är ofta starka inom beläggnings- och krossproduktion. 
De stora aktörerna visar även intresse för drift- och underhållskontrakt, men de dominerande på denna marknad är de statliga producenterna.

Regionala aktörer är ofta företag som agerar i utvalda områden i ett land. De flesta är nischaktörer med bakgrund från maskin-, schaktnings-, betongverksamhet etc. En del har vunnit relativt stora anläggningskontrakt, men har ofta en begränsad ekonomi. Vid flera tillfällen har framgångsrika regionala aktörer blivit uppköpta av större företag.

Företag med stark lokal anknytning fungerar vanligtvis som underleverantörer till de större entreprenörerna och de statliga produktionsverksamheterna. De lokala aktörerna har som regel få anställda, en begränsad ekonomi och ofta en nischverksamhet.

Situationen på dagens nordiska anläggningsmarknad är olika i de nordiska länderna. Danmark har en väl fungerande marknad med ett blandat utbud av nordiska och internationella aktörer. Finland har en entreprenadmarknad med några få stora och ett stort antal mindre aktörer. I Norge finns såväl stora, medelstora som små aktörer medan marknadsbilden i Sverige helt domineras av ett fătal mycket stora företag.

Några fåtal internationella aktörer är idag verksamma i de nordiska länderna och då oftast endast involverade i något eller några större objekt, exempelvis Svinesundsbron - Bilfinger Berger.

\section{Entreprenadmarknaden i Danmark}

I Danmark finns många privata entreprenörer - en stor dansk aktör, flera stora internationella samt många regionala och lokala, ofta specialiserade aktörer. Den enda statliga entreprenören inom anläggningsverksamheten är idag Banedanmark (tidigare Banestyrelsen) producentverksamhet.

På entreprenörsidan tenderar det att bli en koncentration av några stora marknadsaktörer. Efter det att NCC, Skanska och Veidekke etablerade sig gick de två största danska entreprenörerna ihop till ett gemensamt bolag, MT Højgaard. De är nu det största danska entreprenörsbolaget, men i jämförelse med NCC och Skanska ändå litet. Övriga regionala och lokala entreprenörer som utför arbeten åt väg- och banhållningen är bl.a. Ove Arkil, Novejfas, Colas, Phil \& Søn, Per Aarsleff, Zacho-Lind och Petri \& Haugstedt. En sammanställning över omsättningen 2002 för de större entreprenörerna redovisas i bilaga 3 .

Den danska entreprenadmarknaden är mycket flexibel. De mindre entreprenörerna fungerar oftast som underentreprenörer till de större eftersom deras kompetens i huvudsak omfattar utförande vilket innebär att de vid totalentreprenader måste ta hjälp av konsulter eller samarbeta med större företag. 
På anläggningsmarknaden är MT Højgaard marknadsledande avseende nyproduktion. Dessutom finns flera mellanstora och mindre entreprenörer som utför anläggningsarbeten åt Banedanmark och Vejdirektoratet, vilka är marknadsledande inom smalare områden, t.ex. inom driftområden där små firmor är specialiserade på exempelvis betongreparationer, sprickinjektering, målning av stål, asfaltrivning m.m.

\section{Entreprenadmarknaden i Finland}

Omsättningen för de företag som har anläggningsmarknaden som sitt huvudsakliga verksamhetsområde är över 2000 miljoner euro. Det finns över 5000 privata företag av vilka $90 \%$ är små. De stora företagens omsättning utgör dock den allra största delen.

En sammanställning av aktörerna på marknaden finns tillgänglig hos Banförvaltningscentralen, där framförallt leverantörer med riksomfattande verksamhet, som arbetar på ban- och vägarbeten finns redovisade. Utöver dessa fungerar på marknaden flera små lokala mark- och broentreprenörer, som framförallt är verksamma inom väg- och banhållningsmarknaden som underentreprenörer.

Sju stora företag verkar på den finska marknaden för byggande, förbättringarbeten, drift och underhåll: Vägaffärsverket, Lemminkäinen Abp, YIT Abp, Skanska-Tekra Ab, NCC Roads Ab, Terramare Ab och Oy VR-Rata Ab. Ett flertal av dessa stora företag är konglomerat av koncernstruktur, som förutom väghållning också har hus- och industribyggnad på programmet. På beläggningsmarknaden är 13 företag verksamma, varav fyra tillhör de stora konglomeraten. Marknadsandelen för de sex största företagen är över $95 \%$. Mätt i omsättning på väghållningsmarknaden är Vägaffärsverket störst. Dess intåg på marknaden har ökat konkurrensen och den i vägverksreformen föreskrivna konkurrensutsättningen av de allmänna vägarnas väghållning har medfört nya arbeten som är föremål för öppen konkurrens. I bilaga 3 redovisas en sammanställning över de större entreprenörernas omsättning 2002.

\section{Entreprenadmarknaden i Norge}

Anläggningsmarknaden i Norge domineras av fem stora landstäckande aktörer som tillsammans har ca $50 \%$ av norska anläggningsmarknaden. Av de fem är tre norskägda - Veidekke, AF Gruppen och det statligt ägda Mesta samt två svenskägda - Skanska och NCC. En sammanställning över omsättningen 2002 för de större entreprenörerna redovisas i bilaga 3 .

Inom anläggningsmarknaden råder fortsatt stor flexibilitet med många mindre maskinentreprenörer som kan ta mindre uppdrag eller arbeten som underentreprenörer samtidigt som det finns många små och mellanstora regionala aktörer som kan konkurrera med de nationella entreprenörerna. 
Inom beläggningsverksamheten domineras marknaden till $99 \%$ av sex aktörer. De fyra största är Veidekke, NCC Roads, Lemminkäinen och Mesta AS med ca $85 \%$ marknadsandelar. De två andra entreprenörerna är Skanska Asfalt och Oslo vei.

Både anläggnings- och beläggningsmarknaden har de senaste åren präglats av uppköp som på beläggningsmarknaden har resulterat $\mathrm{i}$ att de mindre lokala aktörerna nästan helt försvunnit. De stora entreprenörerna äger också många strategiskt viktiga berg- och grustäkter.

Det råder även en viss tendens till att de stora entreprenörerna renodlar kärnverksamheten. Till exempel överförs maskindrift till egna maskinuthyrningsfirmor och de stora entreprenörerna samarbetar i större omfattning med mindre entreprenörer som har specialkompetens.

Marknaden i Norge har inte haft någon tillväxt de senaste åren vilket inneburit att företagen fått kämpa för att få tillräckliga volymer och man har varit tvungen att ta marknadsandelar från konkurrenter för att kunna växa. De stora entreprenörerna har under de senaste åren genomgående haft en låg lönsamhet.

\section{Entreprenadmarknaden i Sverige}

Den svenska företagsstrukturen - med en i vissa avseenden oligopolliknande struktur - är delvis ett resultat av en långvarig lågkonjunktur inom byggindustrin. Antalet aktörer på marknaden har successivt blivit färre. Från att under 1970-talet ha bestått av ett stort antal större och medelstora företag fanns vid utgången av 1997, förutom Vägverket Produktion och Banverket Produktion endast tre rikstäckande företag inom verksamhetsområdet. Avsaknaden av regionala företag är besvärande.

Merparten av entreprenörernas produktion utförs av fristående konsulter, underentreprenörer, åkare och enskilda entreprenadmaskinföretag där fordons- och maskinägarna ofta är enmans- eller fåmansföretag. Lastbilscentraler och entreprenadmaskinföreningar har en stor roll i samordningen och prissättningen av produktionsresurserna.

Vid nybyggnad av icke järnvägsspecifika anläggningar, dvs. markarbeten, broar och tunnlar, finns idag en fungerande men minskande leverantörsmarknad som domineras av Skanska, Peab, NCC och Vägverket Produktion. Därutöver finns ett fåtal större nordiska entreprenadföretag som agerar $\mathrm{i}$ begränsad omfattning. Tillsammans kontrollerar de nästan $80 \%$ av marknaden. I bilaga 3 redovisas en sammanställning över de större privata entreprenörernas omsättning 2002.

För den järnvägsspecifika ny- och ombyggnadsproduktionen (banöverbyggnad) är leverantörsmarknaden begränsad. Utöver Banverket Produktion och 
Banverket Industridivisionen, som dominerar vid nyanläggning av banöverbyggnad, finns ett tiotal nordiska entreprenörer med järnvägsteknisk inriktning. Även de ovan nämnda större anläggningsentreprenörerna kan ta sig an järnvägsspecifika entreprenader. Hittills har detta emellertid endast skett under förutsättning att banunderbyggnadsdelen ingår i det totala åtagandet.

\subsection{Den nordiska järnvägsentreprenadmarknaden}

För den järnvägsspecifika ny- och ombyggnadsproduktionen är leverantörsmarknaden begränsad. Utöver de statligt ägda företagen som dominerar vid nyanläggning av banöverbyggnad, finns ett 10-tal järnvägstekniskt inriktade entreprenörer på den nordiska marknaden. Även andra större anläggningsentreprenörer kan ta sig an järnvägsspecifika entreprenader. Hittills har detta emellertid endast skett under förutsättning att banunderbyggnadsdelen ingår i det totala åtagandet. De statligt ägda entreprenadföretagen uppträder då ofta som underentreprenörer. Mindre entreprenörer, specialiserade inom något eller några teknikslag kan även de förekomma som underentreprenörer.

Drift och underhåll upphandlas normalt som ett serviceåtagande och kräver mer eller mindre ständig geografisk närvaro av entreprenören. Därutöver krävs, inte minst för felavhjälpning och olyckshantering, kompetens inom samtliga järnvägstekniska områden. Verksamhet har inom detta område i princip varit stängd för externa aktörer. De statligt ägda företagen är de absolut dominerande leverantörerna av drift- och underhållsproduktion.

\subsection{Den nordiska konsultmarknaden}

\section{Konsultmarknaden i Danmark}

I Danmark finns flera privata konsulter, antingen mycket stora som COWI, Rambøll, NIRAS och Carl Bro eller mindre specialistkonsulter. Antalet konsultfirmor som arbetar inom anläggningssektorn är dock mycket begränsad, ca tio aktörer har över $90 \%$ av marknaden.

De marknadsledande konsulterna är de fyra nämnda. Av historiska skäl har de haft ett nära samarbete med beställarna som tidigare ansåg att det var en fördel om kompetensen var samlad hos ett fătal aktörer och därför gavs enbart uppdrag till dessa. Numera har EU:s upphandlingsregler medfört att man genom offentlig upphandling måste vända sig till fler aktörer.

De senaste åren har danska konsultföretag gått ihop med andra stora nordiska konsultföretag. Exempelvis har COWI köpt Interconsult AS i Norge och Rambøll har köpt Scandiaconsult i Sverige. 


\section{Konsultmarknaden i Finland}

Inom projektering har man av tradition haft en fungerande marknad i Finland. Vägförvaltningen har t.ex. ett ramavtal gällande anskaffning av konsulttjänster med Vägaffärsverket och 30 privata konsultbyråer.

\section{Konsultmarknaden i Norge}

Konsultmarknaden i Norge har de sista åren dominerats av sex stora aktörer - Norconsult, Interconsult, Multiconsult, Asplan Viak, Rambøll och Statkraft GRØNER - vilka alla hade en omsättning på mer än 35 milj. € år 2002. Tillsammans har de ca $65 \%$ av konsultmarknaden. Den största norska konsulten är Norconsult.

Den resterande marknaden är fragmenterad, med en del stora och medelstora företag och många mindre lokala företag med en årlig omsättning på upp till 2,5 milj. €. En del av dessa är enmansföretag. Totalt finns det mer än 70 företag som har en årsomsättning som är större än 1 milj. $€$.

Den norska konsultmarknaden har de senaste åren genomgått stora förändringar med en ökad grad av fusioner, uppköp och samarbetsavtal. Detta har resulterat $\mathrm{i}$ att flera av de stora konsultföretagen har köpts upp och ingår i stora nordiska och internationella företag. Svenska WSP (tidigare J\&W) har övertagit Multiconsult och Noteby, danska Cowi har köpt Interconsult och danska Rambøll har köpt Scandiaconsult.

\section{Konsultmarknaden i Sverige}

Stora tekniska konsultföretag i Sverige med verksamhet inom Vägverkets och Banverkets verksamhetsområden är SWECO AB, Rambøll (SCC), WSP samt Vägverket Konsult och Banverket Projektering. Dessa företag svarar idag för ungefär två tredjedelar av den tekniska konsultbranschens hela omsättning. Utöver dessa finns ett tiotal icke börsnoterade bolag, varav Tyréns är det mest dominerande. Marknaden kännetecknas av konjunkturkänslighet, hård konkurrens och låga marginaler.

Banverket och Vägverket har ett stort behov av konsultinsatser för att klara sina åtaganden. 1999 köpte Banverket konsulttjänster för ca 108 milj. € från externa och interna konsulter. Andelen konsulttjänster är störst vid nyproduktion, ca $20 \%$ av de totala kostnaderna. Vägverket köpte konsulttjänster för ca 72 milj. $€$ år 2002 varav 28 \% av konsultinsatserna kom från Vägverket Konsult.

\subsection{Statlig producentverksamhet i Norden}

I Norden har de statliga produktionsorganisationerna utvecklats olika. I tabell 3.1 och 3.2 redovisas en sammanställning av de former för konkurrens- 
utsättning av den statliga väg- och banhållningen som använts i Danmark, Finland, Norge och Sverige.

Tabell 3.1 Statliga produktionsresursers verksamhetsformer för väghållningen i Norden.

\begin{tabular}{|c|c|c|}
\hline Nation & Konsultverksamhet & Entreprenadverksamhet \\
\hline Danmark & $\begin{array}{c}\text { Intern resursenhet som arbetar både } \\
\text { internt och externt (primärt internt) }\end{array}$ & $\begin{array}{c}\text { Privata entreprenörer inom anläggning, } \\
\text { underhåll och drift. }\end{array}$ \\
\hline Norge & $\begin{array}{c}\text { Intern resursenhet, tillpassad för } \\
\text { interna behov. }\end{array}$ & $\begin{array}{c}\text { Statligt ägt aktiebolag, som är skilt från } \\
\text { Statens vegvesen. }\end{array}$ \\
\hline Finland & $\begin{array}{c}\text { Statligt ägt Vägaffärsverk som } \\
\text { omfattar konsult och entreprenad- } \\
\text { tjänster. }\end{array}$ & $\begin{array}{c}\text { Statligt ägt Vägaffärsverk som omfattar } \\
\text { konsult och entreprenadtjänster. }\end{array}$ \\
\hline Sverige & $\begin{array}{c}\text { Intern affärsenhet inom Vägverket } \\
\text { som konkurrerar på intern och } \\
\text { extern marknad. }\end{array}$ & $\begin{array}{c}\text { Intern affärsenhet inom Vägverket som } \\
\text { konkurrerar på intern och extern marknad. }\end{array}$ \\
\hline
\end{tabular}

Tabell 3.2 Statliga produktionsresursers verksamhetsformer för banhållningen i Norden.

\begin{tabular}{|c|c|c|c|}
\hline Nation & Konsultverksamhet & $\begin{array}{c}\text { Entreprenadverksam- } \\
\text { het } \\
\text { Anläggning }\end{array}$ & $\begin{array}{c}\text { Entreprenadverksamhet } \\
\text { Drift }\end{array}$ \\
\hline Danmark & Utskild resultatenhet. & $\begin{array}{l}\text { Intern enhet, öppnad för } \\
\text { konkurrerens. }\end{array}$ & Intern enhet. \\
\hline Norge* & $\begin{array}{l}\text { Intern enhet, primärt } \\
\text { anpassad efter interna } \\
\text { behov. }\end{array}$ & $\begin{array}{l}\text { Statligt ägt aktiebolag } \\
\text { (Baneservice). }\end{array}$ & $\begin{array}{c}\text { Ej konkurrensutsatt - ingår i } \\
\text { Jernbaneverket }\end{array}$ \\
\hline Finland & $\begin{array}{c}\text { Statligt ägt aktiebolag } \\
\text { som omfattar konsult } \\
\text { och entreprenadtjäns- } \\
\text { ter } \\
\text { (Oy VR-Rata Ab). }\end{array}$ & $\begin{array}{l}\text { Statligt ägt aktiebolag } \\
\text { som omfattar konsult } \\
\text { och entreprenadtjänster } \\
\text { (Oy VR-Rata Ab). }\end{array}$ & $\begin{array}{l}\text { Statligt ägt aktiebolag som } \\
\text { omfattar konsult och entre- } \\
\text { prenadtjänster } \\
\text { (Oy VR-Rata } \mathrm{Ab})\end{array}$ \\
\hline Sverige & $\begin{array}{l}\text { Intern affärsenhet } \\
\text { inom Banverket som } \\
\text { konkurrerar på intern } \\
\text { och extern marknad. }\end{array}$ & $\begin{array}{l}\text { Intern affärsenhet inom } \\
\text { Banverket som konkur- } \\
\text { rerar på intern och extern } \\
\text { marknad. }\end{array}$ & $\begin{array}{c}\text { Intern affärsenhet inom } \\
\text { Banverket som konkurrerar } \\
\text { på intern och extern mark- } \\
\text { nad. }\end{array}$ \\
\hline
\end{tabular}

* Jernbaneverket i Norge håller på att omorganiseras och formerna är ej fastställda (mars 2004). 


\section{Statlig producentverksamhet i Danmark}

De enda statliga entreprenören i Danmark inom väg- och banverksamheten är Banedanmark-Baneteknik och Banedanmark-Logistik. Baneteknik utför nyinvesteringar och underhåller bantekniska installationer medan Banedanmark-Logistik tillhandahåller komponenter och material i entreprenörsuppdrag.

\section{Statlig producentverksamhet $i$ Finland}

Det finska Vägaffärsverket organiserades i samband med vägverksreformen i början av 2001. Ett affärsverk är enligt finsk lagstiftning organisationsformen för en verksamhet, som behöver en av staten ledd samhällelig styrning. Dessutom är affärsverksreformen ett mellanskede för sådana produktionsorganisationer som fungerat som ämbetsverk men har bolagiserats och därefter eventuellt kommer att privatiseras.

Vägaffärsverket är helt fristående från Vägförvaltningen och verkar på marknaden som övriga entreprenörer. Dess verksamhetsområde omfattar i första hand konsultverksamhet, byggande, underhåll och drift av trafikleder och trafikmiljö. Dessutom ingår färjerederiet i Vägaffärsverket. Största kunden är Vägförvaltningen. Övriga kunder är bl.a. affärsföretag, kommuner och statliga ämbetsverk. Vägförvaltningens andel av volymen var $200380 \%$ (2002 86 \%), men de övriga kundernas andel har kontinuerligt ökat.

När Vägaffärsverket grundades beslutades det samtidigt om en fyraårig övergångsperiod. Enligt den öppnas Vägförvaltningens alla arbeten för öppen konkurrens före utgången av 2004. I början av 2003 var hälften av driftsverksamheten konkurrensutsatt och de sista driftområdesentreprenaderna kommer att upphandlas 2004. Konsultverksamheten konkurrensutsätts efter samma förutsättningar och tidtabell. Anläggnings- och beläggningsverksamheten var däremot redan helt konkurrensutsatt 2002. Vägaffärsverkets omsättning var 2003543 milj. $€$ (2002 över 550 milj. €). Vinsten var 13,4 milj. $€$ (2002 12 milj. $€)$, vilket motsvarar 2,5 \% (2002 2,2 \%) av omsättningen. Antalet anställda var 3641 (2002 3 800).

Oy VR-Rata Ab är idag klart störst bland företag som erbjuder banhållningstjänster i Finland. Företaget tillkom när Statens järnvägar bolagiserades 1995 då banbyggande-, underhålls-, planerings- och materialverksamheten fördes samman. Företaget är en fast del i den statligt ägda VR-koncernen. Största delen av Oy VR-Rata Ab:s omsättning utgörs av arbeten för statens järnvägsnät beställt av Banförvaltningscentralen (Ratahallintokeskus), dessutom utför företaget arbeten åt bl.a. kommuner, hamnar och industrier. Dotterföretag ägda av Oy VR-Rata Ab är Megasiirto Oy som är specialiserad på flyttning av järnvägsbroar samt ett dotterföretag i Estland. I Oy VR-Rata Ab pågår utredningsarbete om organisationens förnyelsebehov. Företaget har 
under de senaste åren fortlöpande minskat antalet fast anställda för att anpassa sin verksamhet till marknadssituationen. Omsättningen har under de senaste åren varit omkring 250 milj. $€$ per år. Företaget har ca 2500 personer anställda, varav knappa 1000 är specialiserade i järnvägarnas el- och säkerhetsanordningsteknik.

\section{Statlig producentverksamhet $i$ Norge}

Statens vegvesenets produktionsavdelning etablerades som enhet 1995. I november 2001 tog norska Stortinget beslut om att bolagisera och därmed konkurrensutsätta produktionsdelen. Den 1 januari 2003 skiljdes därför produktionsverksamheten från vegvesenet och fick företagsnamnet Mesta AS och är därmed bolagiserat. Vid förändringen fick Mesta överta en del löpande driftkontrakt, men skall till 2006 vara fullt konkurrensutsatt. De offentligt ägda sällskapen Mesta (skilt från Statens vegvesen) och Oslo vei (skilt från Oslo veivesen) arbetar i full konkurrens på samma grunder som de privata aktörerna med motsvarande lönsamhetskrav.

Mesta AS är organiserad i tre regioner. Huvudorter är Bodö, Bergen och Oslo. Anläggningsverksamheten har konkurrensutsatts till $100 \%$ redan från starten. Kontrakt som upprättats i den gamla organisationen slutförs av Mesta AS, därefter blir allt konkurensutsatt. Vid omorganisationen i början av 2003 var antalet anställda 4500 men en analys före bolagiseringen har angett att bolaget borde kunna reducera sin personal med ca 1500 personer under en treårsperiod. Mesta AS har satsat på tre produktområden - Drift, Asfalt och Anläggning.

Från och med januari 2004 har Jernbaneverket en ny organisation som i princip består av två divisioner plus en central stab. De två divisionerna är Trafik och Infrastruktur. Infrastrukturdivisionen genomför arbeten inom anläggningsmarknaden med investeringar för ca 240 milj. $€$ per år. I den nya organisationen skall regionerna i princip vara förvaltare av infrastrukturen och ansvara för drift- och delar av underhållsarbetet. Utbygging skall vara leverantörer av interna tjänster till förvaltaren. Styrning och uppföljning av investeringar vad avser projektering och byggande av nya anläggningar kommer att utföras av Utbygging.

Fortsättningsvis kommer all bygg- och anläggningsverksamhet, nya bantekniska anläggningar samt större maskinella underhållsarbeten att vara konkurrensutsatta - totalt ca 300 milj. $€$. Dessutom kommer konsultverksamheten att konkurrensutsättas inom de områden där Jernbaneverket inte har egen kompetens.

\section{Statlig producentverksamhet $i$ Sverige}

I enlighet med den av riksdag och regering beslutade inriktningen har sedan 1992 en successiv konkurrensutsättning genomförts av den statliga väghåll- 
ningsproduktionen. Idag upphandlas i anbudskonkurrens allt nybyggande, all drift- och underhållsverksamhet liksom nästan all teknikkonsultverksamhet. Vägverket Produktion, Vägverket Konsult och Färjerederiet är affärsenheter inom verket och bedriver verksamhet i bolagsliknande former. Vägverkets ledning styr verksamheten bland annat genom att ställa upp resultatkrav.

Vägverket Produktion är sedan 1992 en ny aktör på anläggningsmarknaden och bedriver byggnads-, drift och underhållsverksamhet inom väg- och anläggningsområdet. De restriktioner som lagts på verksamheten bland annat när det gäller tillåten marknad och begränsningar i att förvärva strategiska kompletterande verksamheter gör att ca $90 \%$ av kunderna är offentliga beställare. Marknadsandelen avseende Vägverkets driftuppdrag uppgick 2002 till $62 \%$ och anläggningsverksamhet till ca $34 \%$. Vägverket Produktion har gått ifrån sin geografiska organisation och istället inrättat de rikstäckande affärsområdena Anläggning, Drift, Beläggning samt Fastighet och maskin. Avsikten är att skapa bättre samordning mellan affärsområdena samt uppnå ett mer enhetligt agerande på väg- och anläggningsmarknaden. Omsättningen under 2002 var 631 milj. $€$. Vinsten var 7,6 milj. $€$ vilket motsvarar 1,2\% av omsättningen och antalet anställda 2002 var 2630 personer - en reduktion från starten av konkurrensutsättningen 1992 på ca 3800 personer.

Vägverket Konsult utför konsulttjänster inom trafik-, mark- och anläggningsområdet i hela Sverige. Verksamheten omfattar planering, projektering, konstruktion, byggledning, kontroll och rådgivning. Vägverket Konsult utför också riktade uppdrag inom bl.a. miljöteknik, vägarkitektur, geoteknik, broteknik, trafiksäkerhet, väginformatik och trafikrelaterad information. Vägverket konsults omsättning ökade 2002 med ca 15 \% jämfört med föregående år och uppgick till 47 milj. $€$. Konkurrensutsatta uppdrag åt Vägverket utgjorde $200272 \%$ av omsättningen, icke konkurrensutsatta $7 \%$ och uppdrag åt utomstående $21 \%$. Antalet anställda var 2002, 428 personer.

Banverkets organisation är uppdelad i beställare och utförare. Banverket Produktion, Banverket Projektering, Industridivisionen, Banverket Data, Banskolan och Materialservice är resultatenheter inom verket och bedriver verksamhet i bolagsliknande former. Enheterna har tillsammans ca 4200 personer anställda.

Banverket Produktion har resurser i form av personal, maskiner och fordon för alla förekommande järnvägsspecifika arbeten, dvs. drift, underhåll samt ny- och ombyggnation. Den dominerande kunden är Banverket, som står för $95 \%$ av omsättningen. Industridivisionen genomför järnvägsspecifika entreprenader inom produktområdena ny- och ombyggnad över hela landet. Divisionen har verkstad för prefabricering av komponenter och delsystem. Därutöver svarar divisionen för impregnering av träslipers samt renovering och 
svetsning av räler. Även för Industridivisionen är Banverket den absolut största kunden. Banverket Projektering är ett internt tekniskt konsultföretag. Banverket stod 1999 för $96 \%$ av omsättningen. 



\section{Analys och värdering av marknaden}

\subsection{Allmänt}

Dagens branschstruktur kännetecknas på några av de nordiska anläggningsmarknaderna av låga anbud vilket har lett till svag produktivitets-, teknikoch produktutveckling, små forskningsinsatser, låg lönsamhet, dålig erfarenhetsåterföring, vilket $\mathrm{i}$ sin tur leder till kortsiktigt agerande och minskat förtroende mellan beställare och utförare. I det mest ogynnsamma fallet kan situationen beskrivas som ett negativt utvecklingsförlopp - "Circle of regret", figur 4.1.

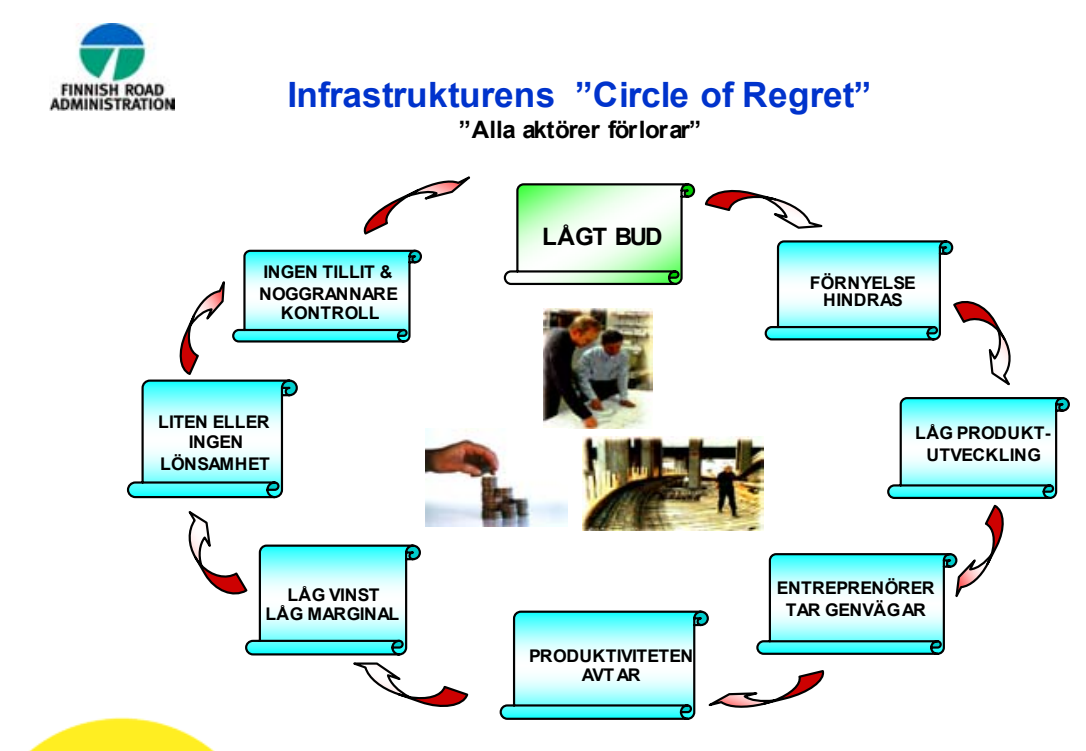

Figur 4.1 "Circle of Regret" (Världsbanken).

Eftersom dagens process inte skapar förutsättningar för att nå ett positivt slutresultat bör en översyn och förändring ske vad gäller förutsättningarna för branschens aktörer att verka på marknaden. Den långtgående planeringsprocessen leder till svårigheter att leverera den initialt efterfrågade produkten inom rätt budget. Därutöver leder den upphackade produktionsprocessen till att erfarenhetsåterföring mellan skedena försvåras. 


\subsection{Strukturförändringar}

Den strukturomvandling där regionala och lokala företag successivt genom förvärv och fusioner kommit att uppgå i större företag har delvis framtvingats av konjunkturnedgångar vilket illustreras för Sverige och Norge i tre figurer (figur 4.1, 4.2 och 4.3). Motiven har varit bl.a. att skapa stordriftfördelar och åstadkomma en diversifiering för att på så sätt bättre klara branschens konjunktursvängningar. Anläggningsbranschen har genom denna strukturomvandling kommit att kännetecknas av ett litet antal stora företag och ett stort antal små företag.

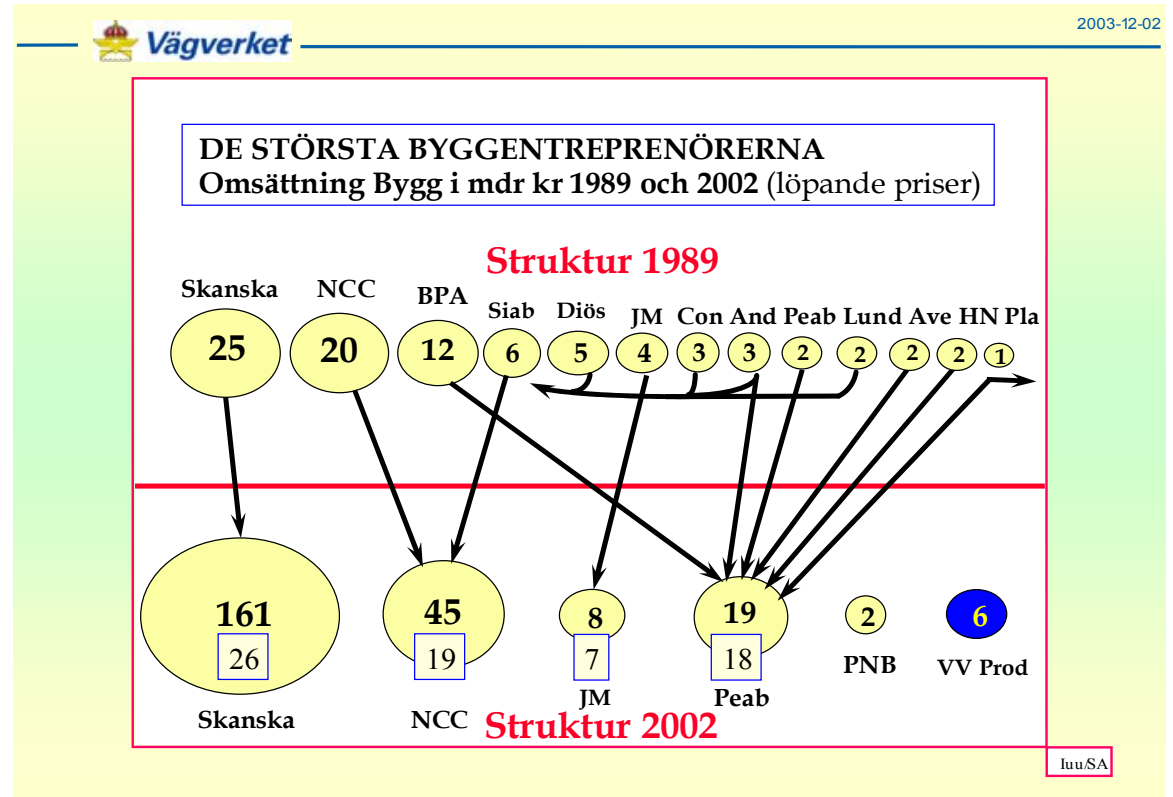

Figur 4.1 Strukturförändring inom entreprenadmarknaden i Sverige 1989-2002. (Vägverket)

Figuren ovan visar antalet byggföretag i Sverige med en årsomsättning som överstiger en miljard kronor respektive år 1989 och 2002. De kompletterande rutorna för 2002 anger omsatt volym på den svenska marknaden.

Liknande tendenser till strukturförändringar sker även i Norge. Ett tydligt exempel på att det skett många förvärv och fusioner av företag under 1990talets senare del kan ses i figur 4.2. 


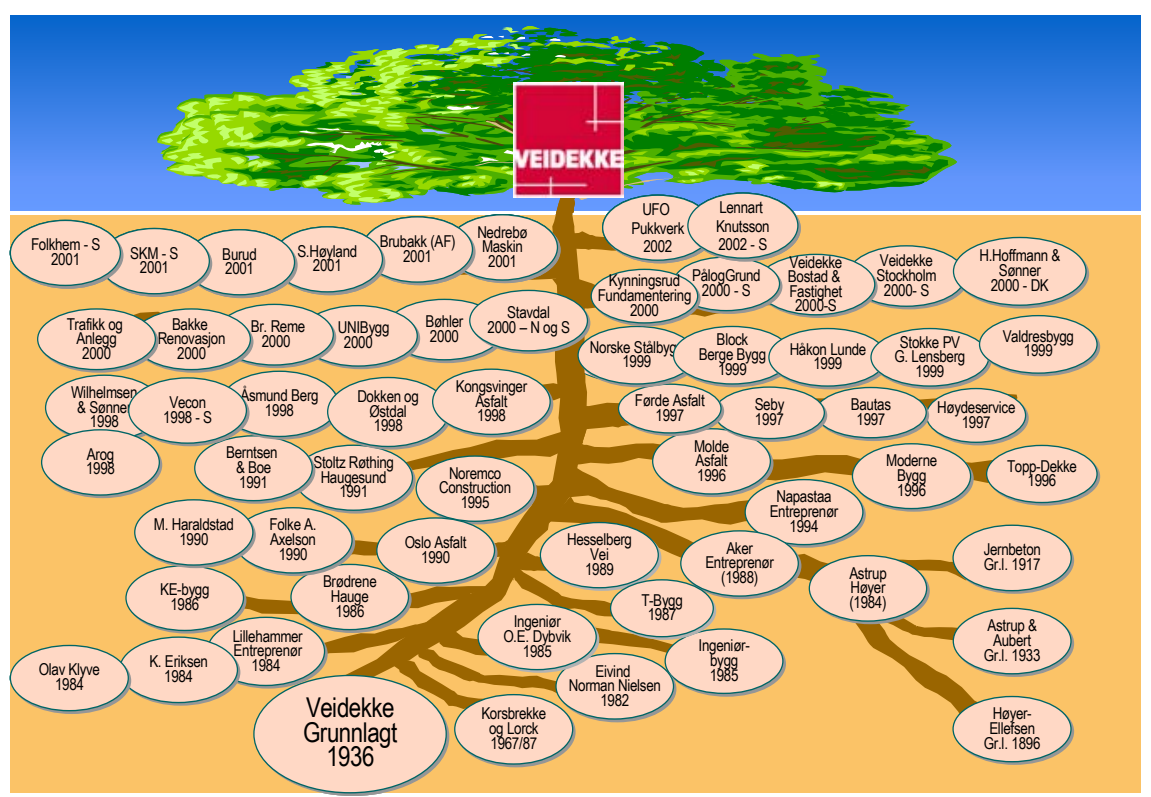

Figur 4.2 Veidekkes förvärv och fusioner av företag från 1936 till 2002. (Veidekke)

Liksom för entreprenadmarknaden har strukturförändringar även skett inom konsultmarknaden. Konsultföretagen blir allt färre men större och inslaget av utländska aktörer och utländska ägarintressen ökar.

Leverantörsmarknadssituationen inom anläggningsbranschen är inte tillfredställande. Det finns ett fåtal stora leverantörer som kan ta sig an stora objekt och en mängd små leverantörer som agerar på de lokala marknaderna främst i underleverantörsledet. Avsaknaden av medelstora företag är besvärande. Dessa kan ha en stor betydelse som konkurrenter till de stora företagen inom olika regioner.

Leverantörsmarknaden måste förändras. Marknaden bör innehålla en jämn fördelning av leverantörer som kan agera både på de nordiska, nationella, regionala och lokala marknaderna. De nordiska trafikverken bör se över möjligheten att aktivt skapa förutsättningar till att förändra dagens situation. Detta kan ske genom att hinder analyseras, prioriteras och i största möjliga mån elimineras och att samarbetsformerna i branschen utvecklas. 


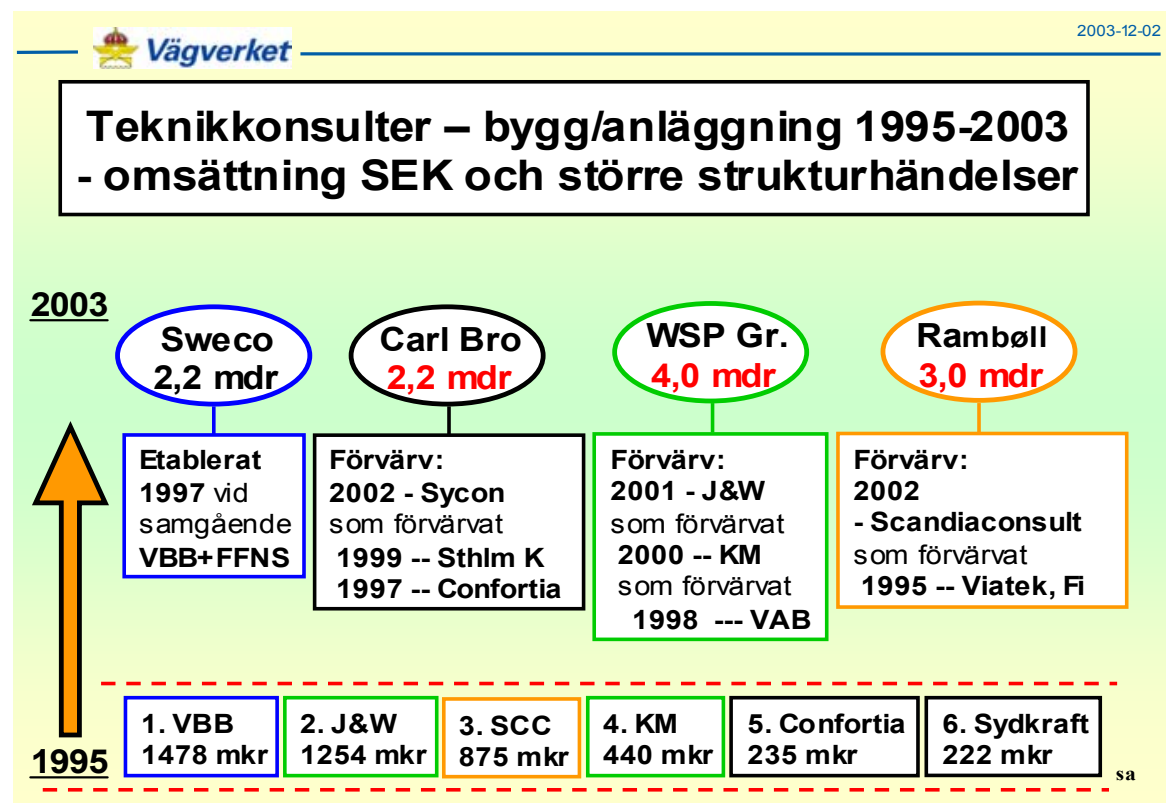

Figur 4.3 Strukturförändring inom konsultmarknaden i Sverige 1995-2003. (Vägverket)

\subsection{Förändringar av statliga producentverksamheter}

Flera av de nordiska statliga producentverksamheter är idag helt eller delvis fristående från väg- eller järnvägsförvaltningarna och fungerar på marknaden som övriga entreprenörer. Avsikten är att effektivisera väg- och banhållningen och att utveckla branschen genom att låta den i ämbetsverksform fungerande produktionen börja fungera på företagsekonomiska grunder.

Den statliga producentverksamheten har haft en betydande påverkan på anläggningsmarknaden. Särskilt tydligt är att priserna på beläggningsarbeten sjunkit kraftigt i Norge sedan Vegvesenet startade med egen produktion.

När det gäller såväl ban- som väghållningen har förändringarna för de statliga producentverksamheterna i de nordiska länderna under de senaste åren organisatoriskt utvecklats mycket olika. I Norge har Vegvesenets egenregiproduktion omvandlats till aktiebolag medan banförvaltningen inte konkurrensutsatt sina produktionsenheter utan dessa ingår fortfarande i Jernbaneverket. En av enheterna - Baneservice - kommer dock att bolagiseras under 2004. I Finland har alla produktionsenheter omvandlats till ett statligt affärsverk med inriktningen att bolagiseras under 2005 medan såväl Vägverket 
Produktion som Vägverket Konsult i Sverige är affärsenheter inom Vägverket. I Danmark upphandlas sedan länge all statlig väghållningsproduktion på marknaden medan banhållningen sköts av Banedanmark. De olika formerna ger möjligheter för framtiden men också begränsningar och restriktioner eftersom samarbetet endast kan ske i uppdragsform och avtalsregleringar i enlighet med gällande förordningar.

I figur 4.4 redovisas översiktligt aktuellt organisationsskede för respektive lands statliga producentverksamhet.

Vägverket

Organisationsreformer i Norden

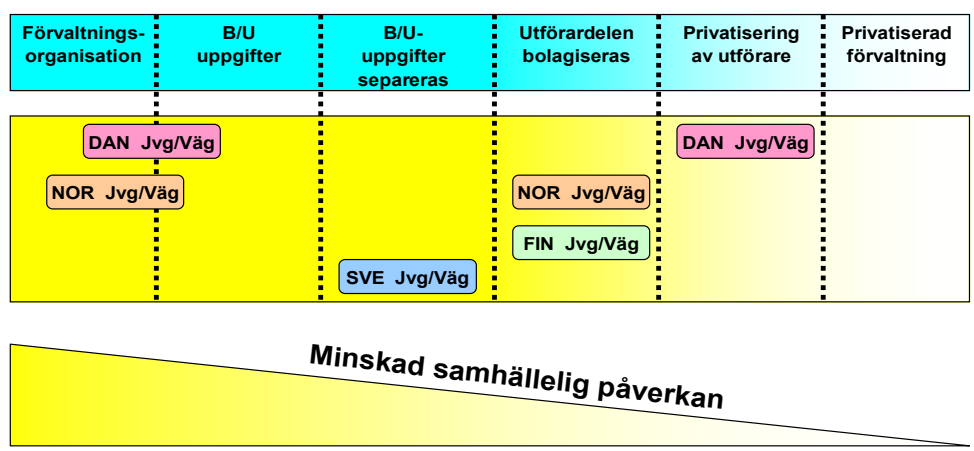

Figur 4.4 Organisationsreformer inom statlig sektor.

\subsection{Insatsvarornas betydelse för anläggningsmarkna- den}

Tillgången på insatsvaror - t.ex. bindemedel, betong, slipers, naturgrus och berg - varierar i länderna och mellan olika regioner vilket kan medföra bl.a. längre och dyrare transporter.

Av olika insatsvaror förorsakar betong- och stenmaterial de största problemen eftersom den lokala tillgången varierar kraftigt. För stenmaterial är det frågan om lokala geologiska förhållanden medan betongstationernas läge till stor del bestäms utgående från marknadssituationen.

Insatsvarornas betydelse för marknadssituationen är inte bara en strategisk entreprenörfråga utan den är i hög grad påverkbar för beställarna. 
Det sägs att det inte är de fysiska möjligheterna att införskaffa byggmaterial som har någon reell betydelse för de enskilda marknadernas val av byggnadsmaterial. Däremot har traditioner, krav i normer och standarder, ovilja till förändringar, marknadsavtal (lovliga och olovliga) - och i ett visst avseende priset - en avgörande betydelse. Cement säljs t.ex. som exportvara på världsmarknaden - exempelvis har det danska Ålborg Portland sålt cement till USA - medan det $\mathrm{i}$ stort sett inte säljs någon vanlig cement till andra nordiska länder.

\section{Insatsvarornas betydelse för anläggningensmarknaden - väg}

För strategiska insatsmaterial uppvisar den svenska leverantörsmarknaden monopol- eller oligopolliknande tendenser för bl.a. följande produkter:

- $\quad$ bitumen - i praktiken monopol

- varma asfaltmassor - NCC och Skanska har ca $75 \%$ av den totala marknaden

- kalla asfaltmassor - Vägverket Produktion är marknadsledande

- cement - i praktiken monopol

- fabriksbetong - monopol eller oligopolliknande marknader dominerat av fem aktörer

- strategiska berg- och grustäkter - domineras nationellt av de rikstäckande företagen.

De stora företagens dominans på marknaden hänger bl.a. samman med dessa produkter. Konkurrenterna är hänvisade att köpa insatsmaterial från dem. Inom lokala och mindre regionala marknader kan enskilda aktörer, inbegripet Vägverket Produktion, ha en monopolliknande situation.

Inom övriga nordiska länder finns inte samma problembild, men den svenska situationen kan stå som ett exempel på hur insatsvarorna kan styra den totala marknadsutvecklingen.

Insatsvarornas betydelse för anläggningensmarknaden - järnväg

I likhet med andra branscher är det totalkostnaden för järnvägsanläggningens tillkomst, drift och avveckling som styr järnvägsförvaltningarnas val av tillvägagångssätt när det gäller materialförsörjning. Försörjningskedjan kan grovt delas upp i tillverkning, transporter, lager samt planering och beredskap.

En järnvägskropp består av en banunderbyggnad inklusive konstbyggnader som är uppbyggd på ungefär samma sätt som en vägkropp och en banöverbyggnad bestående av ett bärlager av makadam eller grus, slipers, räl och växlar. För materialet till underbyggnaden liksom för makadam- eller grus- 
bärlagret i överbyggnaden är transportkostnaderna helt avgörande och närhetsprincipen viktig. Bärlagermaterialet måste dock ha en viss kvalitet varför råvarutillgång och krossresurser också kan påverka så att parametrarna råvara, transporter och tillverkning balanserar. Samma sak gäller för slipers och betongdetaljer. Räl, växlar och andra komponenter som ingår i spåret är vitala för säkerheten varför kvalitet och effektivitet vid tillverkningen är överordnad transportkostnaderna.

Då järnvägsförvaltningarna till övervägande del står som ensam kund på järnvägsspecifikt material får även planering, lager och beredskap stor betydelse:

- Planering krävs för att kunna hantera volymen i flödet. Jämn beläggning är en av nycklarna till låga tillverkningskostnader.

- Lager måste användas som ett samordnande logistikverktyg då objekt $\mathrm{i}$ anläggningen innehåller komponenter från tillverkare från olika delar av världen. En kilometer ny järnväg innehåller ca 500 olika komponenter från ca 300 tillverkare och leverantörer.

- Beredskap när det gäller akut felavhjälpning och underhållsarbeten med kort framförhållning till ett system som har en livslängd på upp till 60-70 år beroende på vilken del i anläggningen det rör sig om och vilken bandel som det gäller.

\subsection{Kompetensförsörjning}

Det finns en stark hotbild som gäller anläggningssektorn som helhet och som kan beskrivas på följande sätt:

- Dåligt engagemang för utveckling inom sektorn.

- Avsaknad av incitament för teknisk utveckling i företagen.

- Stora rekryteringsbehov på grund av sektorns åldersstruktur.

- Minskade resurser för forskning och utbildning.

- Svagt intresse hos unga människor för anläggningssektorn.

- Behovet av kompetensutveckling förstärks än mer av de starka förändringar som pågår i samhället som helhet - t.ex.:

- Förändrade samhällskrav - nya kundkrav och restriktioner.

- Förändringar inom sektorn - nya samverkansformer och ny teknik.

- Ökande internationalisering - nya marknader och ny konkurrens. 
- Förändrad finansiering av forskning och utveckling - en utmaning för utbildning och forskning.

- Nya och tvärfackliga kompetensbehov.

De nya genomförandeformerna har inneburit ökad fokusering på kompetensfrågorna där allt färre söker sig till anläggningsbranschen samtidigt som såväl beställare som utförare konkurrerar om de knappa kompetenser och resurser som finns.

Sektorns kompetensförsörjningssituation är allvarlig med en hög medelålder hos de som idag är verksamma i branschen och som inom de närmaste åren kommer att ge ett mycket stort nyanställningsbehov. Men om dessa behov ska kunna förverkligas måste branschen finna former som intresserar unga människor och som ger alla möjlighet att använda all sin kunskap, kreativitet och engagemang oberoende av vilken "spelhalva" man tillhör - oberoende av om man är beställare eller utförare.

\subsection{Lönsamhet}

En bidragande orsak till den aktuella marknadssituationen med ett fåtal dominerande aktörer på utförarsidan är den låga lönsamhet som anläggningsverksamheten haft under många år och som tvingat fram strukturförändringar samtidigt som produktivitetsutvecklingen ändå varit låg. Trots ett omfattande ansvar och stort risktagande ligger lönsamheten normalt inte högre än 1 till $3 \%$ vilket inte ger några förutsättningar för ett mer långsiktigt agerande utan i stället sätter fokus på att hålla en så billig produktionsorganisation som möjligt för att överleva.

Många av de stora företagen har parallellt med sin anläggningsverksamhet annan verksamhet som t.ex. fastighets- och kapitalförvaltning som oftast ger en betydligt bättre avkastning än deras kärnverksamhet. De mindre aktörerna liksom de statliga produktionsverksamheterna har inte sådana möjligheter och innebär t.ex. att lönsamheten för en del statliga producenter är låg och de har mycket svårt att få ett positivt finansiellt resultat.

Med de nuvarande lönsamhetsnivåerna finns inga stora utrymmen för en mer långsiktig kompetens- och produktivitetsutveckling och kan vara en viktig förklaring till många av de problem som branschen upplever idag. En erfarenhet är att för att en utförare skall ha möjlighet att engagera sig även i olika utvecklingsprojekt bör lönsamheten ligga på nivån 6 till $7 \%$ vilket inte bara skulle vara till nytta för utförarna utan i lika hög grad för beställare och kunder. 
En målsättning borde vara att utveckla upphandlingsformer som möjliggör att utförarnas innovationer och utvecklingsarbete utnyttjas bättre med bl.a. beaktande av livslängdskostnader, minskad miljöpåverkan och höjning av produktiviteten och därigenom förbättra verksamhetens lönsamhet.

\subsection{Teknikutveckling}

Sedan konkurrensutsättningen av väghållningsproduktionen startade har den produktionstekniska utvecklingen avtagit kraftigt i många av de nordiska länderna. En anledning är att beställarorganisationerna ansett att entreprenörssidan ensam skulle ansvara för den typen av utveckling och att den i sig borde vara en viktig konkurrensstimulerande faktor.

I den uppföljning av konkurrensutsättningen som Riksrevisionsverket i Sverige gjorde 1998 - "Sex år med beställar/utförarmodellen" - betonar man att beställaren har ett ansvar för att säkra en långsiktig teknikutveckling och att vissa tekniska processer innefattar så höga initialkostnader att en enskild entreprenör inte ensam kan klarar av finansieringen.

Vägverkets erfarenhet från den gångna perioden är också att man som väghållningsmyndighet har ett ansvar för att även metoder och teknik av produktionsteknisk karaktär ständigt förbättras. Detta gäller inte minst för att kraven på en miljö- och trafiksäkerhetsanpassad produktion ska kunna förverkligas.

I det nya programmet för forskning, utveckling och demonstration som verket fastställt för perioden 2004 till 2013 har man därför skapat ett utvecklingsområde för att stödja den produktionstekniska utvecklingen där samtliga aktörer inom branschen kan söka medel för framtagning, utvecklig och demonstration av nya produktionstekniska hjälpmedel.

\subsection{Framtida omsättning på anläggningsmarknaden}

Nedan följer en ansats till att försöka bedöma anläggningsmarknadens omsättning i de nordiska länderna under de närmaste 10 åren. Förändringar kan ske snabbt beroende på politiska beslut, långsiktiga planer som förverkligas genom ettåriga budgetar, valutafluktationer etc. I bilaga 2 redovisas en sammanställning av årliga volymer uppdelade på investering, drift och underhåll avseende åren 2003, 2004 och 2012. Observera att variationer kan förekomma avseende ländernas innehåll i respektive anslagspost.

\section{Danmark}

I Danmark har byggandet under en period minskat påtagligt, men nu väntas en återhämtning inom många sektorer. I och med de mycket stora anlägg- 
ningsuppdragen - Storebælt (klart 1998) och Öresund (klart 2000) - kommer dock anläggningsmarknaden att vara begränsad.

Inom de närmaste tio åren förestår en utbyggnad av motorvägar från fyra till sex filer, liksom en uppgradering av järnvägen i Köpenhamnsområdet. Dessutom planeras en utbyggnad av Köpenhamns tunnelbanesystem. Det finns även några planerade mellanstora anläggningsprojekt i Ålborg, Århus och Silkeborg.

Bedömningen i Danmark är att investeringsvolymerna inom anläggning kommer att vara i storleksordningen 1340 - 2019 milj. $€$ under de närmaste tio åren. Ett eventuellt beslut att etablera en förbindelse mellan Danmark och Tyskland kommer att öka investeringsvolymen i slutet av perioden.

\section{Finland}

För Finland gäller en fortsatt stark byggkonjunktur där framför allt bostadsbyggandet utvecklas, även anläggningsbyggandet som har sin tyngdpunkt $\mathrm{i}$ södra Finland beräknas öka i år och de kommande åren.

På järnvägssidan kommer endast några helt nya förbindelser att byggas t.ex. banan mellan Kervo och Lahtis som beräknas få en årsbudget på 50-100 milj $€$.

På vägsidan ökar investeringarna och bl.a. genomförs några stora projekt med en årsbudget för motorvägsbyggande på 10-25 milj $€$.

Nivåerna för drift och underhåll är ungefär de samma som tidigare år men med en 40-50 procentig ökning av broreparationsvolymerna fram till 2012.

\section{Norge}

I Norge har utvecklingen för anläggningsbyggandet varit svag i flera år. Ändå har det totala byggandet ökat om än marginellt. Bedömningen är att investeringsvolymerna på väg- respektive bansidan kommer att minska något under den kommande 12-årsperioden. Väginvesteringar beräknas minska från nuvarande ca 960 milj. $€$ per år till en nivå strax under 900 milj. $€$ per år 2012. För drift, underhåll och bärighet sker dock en ökning med ca 76 milj. till nivån 900 milj. $€$ per år.

För järnvägarna är bedömningen att investeringsvolymerna kommer att bli ca 190 milj. $€$ som ett genomsnitt under den kommande 12-årsperioden. För drift- och underhåll antas volymen minska med ca $5 \%$.

\section{Sverige}

I Sverige är bedömningen att investeringsvolymerna på vägsidan kommer att minska under de närmaste åren från nuvarande ca 900 milj. $€$ per år till en nivå strax under 660 milj. $€$ per år. För drift, underhåll och bärighet sker dock en ökning med ca 55 milj. till nivån 940 milj. $€$ per år. 
För järnvägarna är bedömningen att investeringsvolymerna kommer att öka till ca 770 milj. $€$ som ett genomsnitt under den kommande 12-årsperioden vilket är en ökning med ca 35 \% i jämförelse med dagens nivå. Inledningsvis kommer dock planen att skjutas framåt beroende på att statens finanser är ansträngda. 



\section{Utvecklingsmöjligheter för anlägg- ningsmarknaden}

\subsection{Allmänt}

Anläggningsbranschen karaktäriseras idag av en mycket traditionell rollfördelning med etablerade genomförandeformer. Till bilden hör dessutom att branschen under senare år fått dålig renommé bland annat genom uppmärksammade kvalitets- och etikproblem. Sektorn måste därför hitta arbetssätt så att alla inblandade parter finner samarbetsformer som ger förutsättningar för ett mer långsiktigt agerande än dagens system med kortsiktiga perspektiv från båda parter.

Väl fungerande anläggningsmarknader och samarbetsformer skapar i idealfallet ett positivt utvecklingsförlopp - "Circel of Hope", figur 5.1.

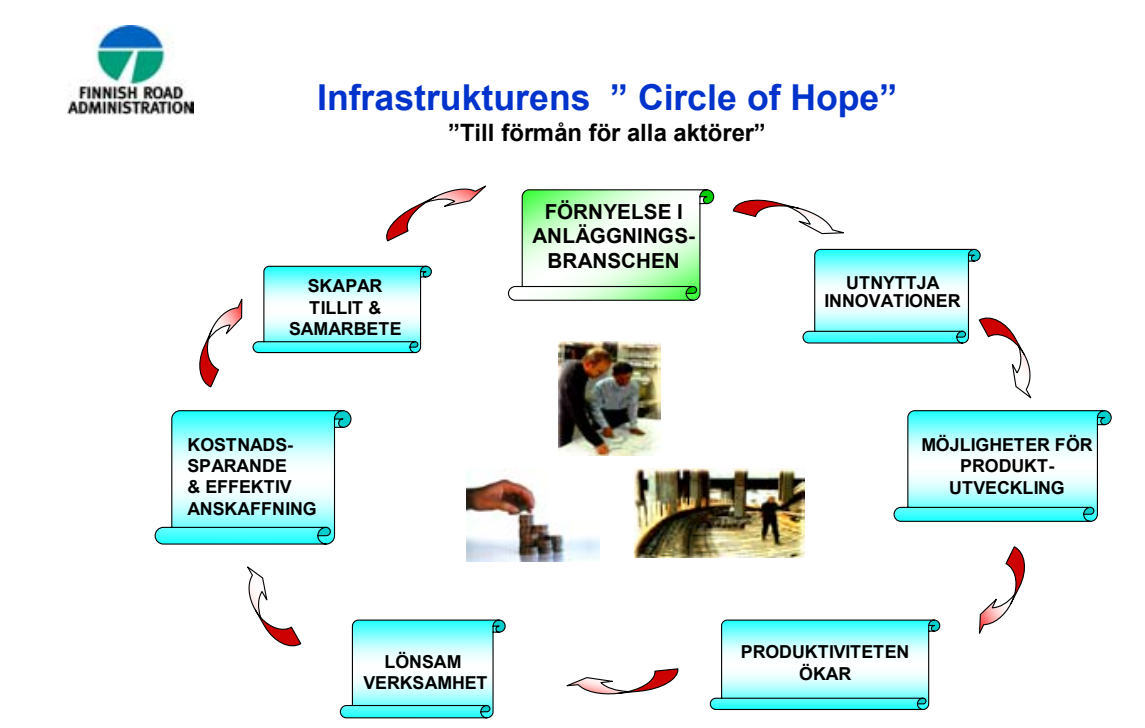

Figur 5.1 "Circle of Hope" (Världsbanken).

En gemensam nordisk anläggningsmarknad kan erbjuda en större marknad för alla aktörer. En mer enhetlig verksamhet inom Norden med en gemen- 
sam målsättning skapar också större möjligheter att tillsammans påverka direktiv och regelverk inom EU. Därutöver ger en större anläggningsmarknad möjlighet att utföra fler olikartade projekt och på så sätt utveckla kunskap och kompetens hos aktörerna.

\subsection{Gemensam marknadsplats}

Flera anläggningsprojekt som pågår samtidigt kan leda till en överhettning av marknaden. En databas med en sammanställning över trafikverkens långsiktiga planer för investeringar, drift och underhåll samt aktuella förfrågningsunderlag skulle kunna vara en möjlighet att sprida information till den nationella, nordiska och internationella leverantörsmarknaden och öka kunskapen om aktuella projekt på såväl lång som kort sikt.

Olika definitioner och skillnader i språk är en annan barriär mellan länderna beroende på att det saknas en entydig terminologi. Finland har redan startat ett nationellt projekt - Infrabyggnadsbranschens allmänna kvalitetskrav (Infra-RYL) - som syftar till att ta fram en gemensam nomenklatur för väg-, gatu- och banarbeten.

En möjlig nordisk framgångsfaktor skulle vara att projektet utvidgades till att ta fram en gemensam ordlista för den nordiska anläggningsbranschen. Ordlistan skulle exempelvis kunna innefatta tekniska begrepp och benämningar på de fyra nordiska språken samt engelska så att databasen även kan bli en plattform för den övriga internationella marknaden.

\subsection{Gemensamma föreskrifter och bestämmelser}

För att en gemensam anläggningsmarknad med fler aktörer ska kunna utvecklas krävs en ökad likformighet i olika föreskrifter och bestämmelser mellan de nordiska länderna. Dessutom bör produkter och utbildningar som godkänts i ett land också vara det i övriga länder med likvärdiga godkännandeprocedurer.

Verka för gemensamma tekniska beskrivningar

Olika tekniska beskrivningar försvårar idag en gemensam anläggningsmarknad. EU-direktiven konvergerar visserligen föreskrifter inom t.ex. områdena arbetsmiljö och miljö, men skillnader finns fortfarande genom kundspecifika tekniska beskrivningar som t.ex. Bro 2002 i Sverige och ABB i Danmark.

\section{Enhetliga allmänna avtalsvillkor}

Skillnader föreligger också mellan Sveriges AB92 och ABT94, Norges NS 8405 och NS 3431, Danmarks AB 92, ABT 93 och ABR 89, samt Finlands YSE 98 även om de många gånger är små. För att en nordisk marknad skall 
kunna fungera med så få hinder som möjligt måste allmänna avtalsvillkor vara likformiga så att ansvarsfrågor kan lösas på ett likartat sätt.

\section{Enhetliga kvalitetskrav}

Trots många likheter har alla länder egna tekniska krav på olika vägprodukter. Förutom att dokumenterade krav följs förutsätter beställaren dessutom att även outtalade krav enligt gällande praxis efterlevs.

Kvalitetskraven bör göras mer enhetliga inom Norden. I Finland har man i det nationella projektet Infra-RYL börjat ta fram en systematik för att forma gemensamma kvalitetskrav för väg-, gatu- och banarbeten.

\section{Verka för gemensamma produktstandarder}

Olika produktstandarder är ett annat område där enhetligheten borde kunna vara betydligt större mellan de nordiska länderna. Exempelvis är standarden för så vanliga produkter som vägmärken och vägutrustning idag olika.

\section{Likformade sätt för att lösa meningsskiljaktigheter}

Entreprenadkulturen uppvisar betydande skillnader mellan länderna i hur man t.ex. tar i tu med och administrerar tvister och meningsskiljaktigheter. Danmark och Sverige har försökt systematisera formerna vilket skulle kunna vara en utgångspunkt för ett utvidgat nordiskt samarbetsprojekt.

\section{Klargör principerna för jäv}

Vid de genomförda konkurrensutsättningarna av den statliga produktionsverksamheten har olika principer för hantering av jävsfrågor använts $i$ de nordiska länderna som kan innebära problem för att uppnå en bättre fungerande nordisk anläggningsmarknad.

Vid konkurrensutsättningen i Sverige skapades inledningsvis en produktionsenhet med kompetens och resurser för projektering, byggande, underhåll och drift. Efter några år delades enheten upp så att alla projekteringsresurser flyttades över i en egen affärsenhet som idag är Vägverket Konsult medan övriga produktionsresurser bildade dagens Vägverket Produktion. Anledningen till uppdelningen var jävsfrågorna där man enligt svensk tolkning av EU-reglerna inte inom samma utförarorganisation först kunde delta $\mathrm{i}$ planering och projektering av ett anläggningsprojekt och senare i en renodlad utförandeentreprenad vara anbudsgivare.

I Finland finns idag kompetens för planering, projektering, byggande, drift och underhåll samlade inom Vägäffärsverket. År 2001 tillsatte kommunikationsministeriet en arbetsgrupp för att precisera spelreglerna vid jävsfrågor. Efter att dessa regler har tillämpats i konkurrensrådet har vägförvaltningen fått ett bra beslutsunderlag varför jävsfrågorna inte längre upplevs som något problem. 
I den nya norska vägorganisationen har man valt att behålla alla projekteringsresurser inom Vegvesenet men det nya produktionsbolaget Mesta AS har full frihet att arbeta även med den här typen av verksamhet.

Vejdirektoratet i Danmark köper sedan mycket länge all entreprenörverksamhet på marknaden och har inte beskrivit några jävsproblem vid upphandling av anläggningsprojekt kopplat mot EU-reglerna.

För att skapa så goda förutsättningar som möjligt för en gemensam nordisk entreprenadmarknad är det viktigt att samtliga nordiska länder har en likartad syn på förekommande jävsfrågor och t.ex. gör samma tolkningar av EUregelverket.

\section{Enhetliga krav för hälsa, miljö och säkerhet}

Det är en förutsättning att bygg- och anläggningsarbeten utförs på sådant sätt att det inte uppstår dödsfall eller skador på personal eller omgivning. Detta är reglerat genom lagar och föreskrifter som lägger ett stort ansvar på både beställare och utförare. För beställarsidan är frågor kring hälsa, miljö och säkerhet (HMS) förankrade i EU-direktiv som ligger till grund för byggherreföreskrifter, utöver de nationella bestämmelserna.

Trots lagar och föreskrifter är bygg- och anläggningsbranschen ofta drabbad av arbetsolyckor på grund av arbetets karaktär och en branschstruktur med många olika företag. Risksituationer som kan uppstå är dels de oavsiktliga som t.ex. dålig utformning av maskiner och arbetsplatser eller brist på kunskap och dels de avsiktliga som t.ex. genvägar i arbetssätt och arbetsmoment samt nedprioritering av säkerheten. Det finns även organisatoriska fel, exempelvis dåliga regler och rutiner samt organisationens oförmåga att lära av egna och andras misstag. Ledningens syn på säkerhet smittar av sig nedåt $\mathrm{i}$ organisationen och såväl bra som dålig kultur förs vidare.

Bygg- och anläggningsbranschen är också en näring där fysisk belastning och slitage på medarbetare kan vara betydlig.

Det är en stor utmaning att bygga in HMS i organisationen och arbetsmomenten på ett sådant sätt att skador och olyckor undviks, och att arbetet läggs upp så att man undviker onödiga slitageskador.

Projektet har upptäckt att frågor kring hälsa, miljö och säkerhet hanteras och ges olika stor betydelse i de nordiska länderna. I Norge har offshoreverksamheten bidragit till att säkerhetsaspekterna har fått stor uppmärksamhet så att mer fokus lagts på HMS jämfört med de andra nordiska länderna. Det skulle därför vara mycket att vinna på att ha en gemensam genomgång av praxis och vilka krav som ska ställas på såväl beställar- som utförarsidan med utgångspunkt i de erfarenheter som gjorts i Norge. 


\section{Godkännande av järnvägsspecifika entreprenadmaskiner}

Erfarenheter från det nordiska samarbetet visar på betydande byråkratiska svårigheter för att flytta arbetsmaskiner över gränserna. Som exempel kan nämnas att det krävs åtta olika tillstånd för att transportera en arbetsmaskin från Norge till Danmark. För att skapa en entreprenadmarknad inom det järnvägstekniska området är det avgörande att det finns gemensamma regler för exempelvis godkännande av spårtekniska och säkerhetsmässiga krav på maskiner. Vidare bör det vara en likvärdig godkännandeprocedur och att respektive land accepterar godkännande från ett annat nordiskt land.

\section{Enhetliga kompetenskrav}

Varje nordiskt land har egna krav på olika utbildningar och kurser som personalen på en arbetsplats måste ha genomgått. För att t.ex. få arbeta på en vägarbetsplats i Sverige måste man ha genomgått kursen "Arbete på väg" liksom en miljöutbildning och i Finland krävs kurserna Tieturva (Vägsäkerhet) och Ensiapu (första hjälpen). En samordning av dessa obligatoriska kurser och utbildningar borde kunna ske så att en godkänd kurs $\mathrm{i}$ ett land också är godkänd i de övriga.

\subsection{Upphandlingsprocessen}

Under våren 2003 har ett projekt pågått avseende benchmarking av upphandlingsstrategier och upphandlingsförfarande mellan vägverken i Danmark, Norge, Finland och Sverige. I undersökningen jämfördes upphandlingsstrategier, upphandlingsmetoder och framtidsplaner. Nedan följer en sammanställning av en del slutsatser som kom fram vid jämförelsen:

- Om målet är en gemensam nordisk upphandlingsmarknad borde upphandlingsstrategierna vara mer lika än vad de är idag. En gemensam marknad är ett strategiskt beslut som varje beställarorganisation borde ta hänsyn till.

- Strategierna och riktlinjerna borde utvecklas tillsammans med utförarna så att man även tar hänsyn till deras åsikter.

- Upphandlingsstrategin borde utformas så att man kan se en tydlig skillnad mellan den nuvarande situationen och den situationen man vill uppnå.

- En innovativ lösning har nästan blivit ett "modeord" i anläggningsbranschen, men de förlorar för ofta till förmån för de mer traditionella formerna. Man borde därför utveckla ett bättre sätt att jämföra innovativa lösningar med de traditionella. 
- Entreprenadformerna måste utvecklas så att de bättre stödjer användningen av innovativa lösningar. De borde få någon sorts "morot" i anbudsskedet så att utförarna blir mer intresserade. Anbudsskedet borde också vidareutvecklas tillsammans med entreprenadformerna.

- Branschen behöver nya aktörer. Det är därför viktigt att skapa nya förutsättningar där det också finnas bättre möjligheter för internationella utförare att delta i anbudsbegäran.

- Om man vill uppnå en gemensam upphandlingsmarknad i Norden är det viktigt att fă likformade standardiserade anbuds- och kontraktsformulär. Standardiserade formulär skulle vara en stor hjälp för utföraren och det skulle inte spela någon roll i vilket land som entreprenören lämnar anbud.

Om upphandling och genomförande sker på snarlikt sätt i hela Norden förenklas samarbetet och riskerna minskar för anbudsgivare. Utöver detta skulle även de nordiska länderna ha en bättre möjlighet att påverka regler, förordningar och direktiv som ställs inom EU.

En annan möjlighet är att ta bort stämpeln "gammalmodig" genom att använda och utveckla informations- och kommunikationstekniken i upphandlingsprocessen. I de nordiska länderna är kunskapen om informations- och kommunikationsteknik mycket hög och det bör finnas goda förutsättningar för att utveckla och förbättra användandet av informations- och kommunikationstekniken i upphandlingsprocessen. Exempelvis skall Vägförvaltningen i Finland år 2006 övergå till elektronisk anbudsbegäran.

En gemensamt framtagen vision för leverantörsmarknaden skulle främja den fortsatta processen för att nå en mer rörlig marknad inom Norden och EU. Visionen skall avspegla viljan från verken att skapa rätt förutsättningar för en öppnare marknad och underlätta för leverantörer att våga ta risken att röra sig över gränserna.

\subsection{Traditionella entreprenad- och samarbetsformer}

Inom projektet "Upphandling av väginvesteringar inom de nordiska länderna" utfördes även benchmarking av vilka entreprenadformer som nyttjades $i$ respektive nordiskt land vid upphandling. Slutsatsen var att entreprenadformerna måste utvecklas så att de bättre stödjer användningen av innovativa lösningar. Nedan följer en kort beskrivning av några traditionella former som idag förekommer i de nordiska länderna.

\section{Totalentreprenad}

I totalentreprenad har beställaren ett avtal med bara en entreprenör som har ansvaret för genomförandet inklusive projektering. För att utföra olika delar 
av entreprenaden upprättar totalentreprenör i sin tur avtal med konsulter och underentreprenörer. Totalentreprenören måste kunna styra och ansvara för stora helheter. Beställaren ansvarar för att entreprenören får exakta och tydliga funktions- och utförandekrav för projektet.

\section{Generalentreprenad}

I generalentreprenad ansvarar beställaren för all projektering och har ett utförandeavtal med en entreprenör som i sin tur kan ha avtal med underentreprenörer. Generalentreprenören tar hand om samordningen av entreprenadens arbete och har ensam ansvaret för utförandet. Den här formen har en tydlig risk- och ansvarsfördelning utifrån beställarens synvinkel. Detta medför även att entreprenadformen är ganska friktionsfri för beställaren, därför att entreprenören tar hand om arbetets samordning samt kostnadsrisker.

\section{Huvudentreprenad}

I huvudentreprenad är det vanligt att beställaren sluter avtal med en begränsad mängd av entreprenörer. En av entreprenörerna kallas huvudentreprenör och sluter avtal med underentreprenörer. Tekniska delar exempelvis el-, VVS- och hissinstallationer levereras direkt från sidoentreprenörer. Huvudentreprenör har fullt ansvar för allt arbete som han själv eller hans underentreprenörer utför. Med ett separat avtal kan man också komma överens om att huvudentreprenör är ansvarig för koordineringen av arbetsplatsen och uppföljning av de tekniska sidoentreprenörernas arbete.

\section{Delad entreprenad}

I en delad entreprenad delas projektet upp i olika delar där beställaren gör upp avtal med olika entreprenörer. Varje entreprenör fungerar självständigt och har inga inbördes rättigheter eller skyldiheter gentemot varandra. Samordningen av arbetet är oftast beställarens ansvar. Det är också möjligt att överföra samordningsansvaret till en av entreprenadens entreprenörer, som då kallas huvudentreprenör.

\section{Fackentreprenad}

Fackentreprenad utgår från en uppdelning av entreprenaden i olika arbetskategorier, t.ex. en uppdelning av mark-, bro- och beläggningsarbeten. De olika arbetskategorierna utförs var för sig även om ibland flera arbetskategorier kan föras samman till en entreprenad.

\section{Projektledning och projektledningsservice}

I formen projektledning och projektledningsservice har beställaren ett avtalsförhållande med en utomstående projektledningsentreprenör som är ansvarig för styrningen av projektet, dvs. tidplanering, upprättande av byggarbets- 
plats, avtal med projekteringskonsult och entreprenör etc. Projektledningsentreprenör rapporterar till beställaren. Som betalningsgrund för projektledningsentreprenad används riktpris. Vid underskridande av riktpris utgår en bonus och om det överskrids delas kostnaderna.

Utöver de ovan nämnda entreprenadformerna finns det olika mellanformer. Mellan de nordiska vägverken förekommer skillnader i hur olika entreprenadformer används. I tabell 5.1 och 5.2 finns en uppdelning av entreprenadformer fördelade på respektive land. Jämförelsen gäller främst val av entreprenadform vid investeringsupphandlingar.

Tabell 5.1 Entreprenadformer vid investeringsupphandlingar av väghållningen i Norden de senaste åren (Ranta-Aho).

\begin{tabular}{|c|c|c|c|c|}
\hline Entreprenadform & Danmark & Finland & Norge & Sverige \\
\hline Totalentreprenad & - & $\mathrm{X}$ & $\mathrm{X}$ & $\mathrm{X}$ \\
\hline Generalentreprenad & - & $\mathrm{X}$ & $\mathrm{X}$ & $\mathrm{X}$ \\
\hline Huvudentreprenad & $\mathrm{X}$ & - & $\mathrm{X}$ & - \\
\hline Delad entreprenad & $\mathrm{X}$ & - & $\mathrm{X}$ & - \\
\hline Fackentreprenad & $\mathrm{X}$ & - & - & - \\
\hline $\begin{array}{c}\text { Projektledning \& Projektled- } \\
\text { ningsservice }\end{array}$ & - & $\mathrm{X}$ & - & - \\
\hline Övrigt & - & $\mathrm{X}$ & $\mathrm{X}$ & $\mathrm{X}$ \\
\hline
\end{tabular}

Tabell 5.2 Genomförda entreprenader av Vägförvaltningen och Vägverket år 2002 (Ranta-Aho).

\begin{tabular}{|c|c|c|c|c|}
\hline \multirow{2}{*}{ Entreprenadform } & \multicolumn{2}{|c|}{ Finland } & \multicolumn{2}{c|}{ Sverige } \\
\cline { 2 - 5 } & antal projekt & $\%$ & antal projekt & $\%$ \\
\hline Totalentreprenad & 36 & 21 & 10 & 4 \\
\hline Generalentreprenad & 123 & 72 & 236 & 94 \\
\hline $\begin{array}{c}\text { Projektledning \& Projekt- } \\
\text { ledningsservice }\end{array}$ & 6 & 4 & - & - \\
\hline Övrigt & 3 & 2 & 6 & 2 \\
\hline
\end{tabular}

För att bättre stimulera och öka intresset för en nordisk anläggningsmarknad borde en framgångsfaktor vara att väg- respektive banhållningsförvaltningarna försöker använda flera traditionella och nya entreprenadformer än att helt stringent förlita sig på ett fåtal entreprenadformer. En annan viktig utvecklingsmöjlighet är att i de nordiska länderna tillsammans upprätta och 
utveckla gemensamma beskrivningar av olika förekommande entreprenadformer.

\subsection{Utveckla samarbetsformer}

Ett "VinnaVinna"-system ska ge positiva effekter - inte enbart för beställaren och utföraren utan även för användaren och kunden. "VinnaVinna"principen betyder att:

- upphandlingarna är förmånliga för beställaren

- verksamheten är lönsam för utföraren

- verksamheten motiverar och sporrar personalen

- kunden får en god service.

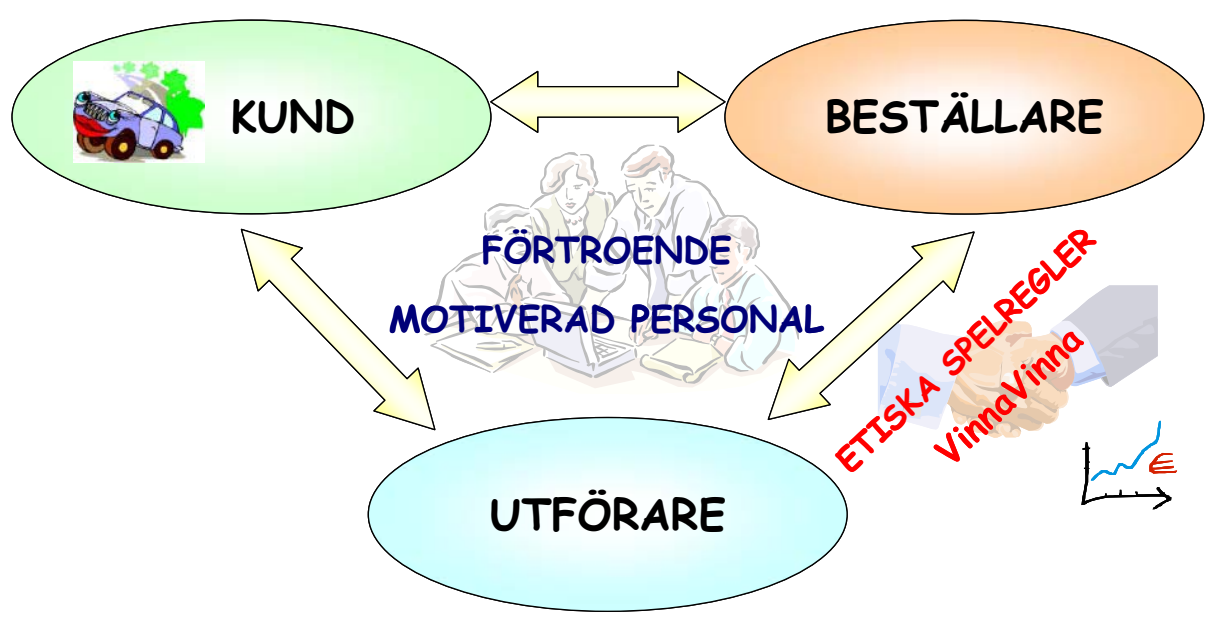

Figur 5.2 Bättre samarbetsklimat (Vägförvaltningen).

Ett bättre samarbetsklimat mellan beställare och utförare borde resultera $\mathrm{i}$ bl.a. följande positiva effekter:

- Att den kunskap och kompetens som finns inom branschen nyttjas på ett för samhället bättre sätt och bör resultera i rätt kvalitet i det som produceras.

- Att förutsättningar skapas för att arbeta mot gemensamma mål där ett delat ansvar bör öka engagemanget för att skapa för samhället optimala produkter och tjänster med rätt standard på olika delar av vägnätet och 
som resulterar i en totalt sett bättre rese- och transportkomfort för användarna.

- Att riskerna fördelas mellan beställare och utförare på ett mer strategiskt riktigt sätt.

- Att beställaren får en optimal kvalitet i de produkter och tjänster som ska produceras vilket ger en optimal användning av tillgängliga medel.

- Att utföraren långsiktigt får en stabilare sysselsättning och därmed en mer stabil lönsamhet.

Formerna för ett utvecklat samarbete mellan beställare och utförare har under senare år prövats bl.a. genom Partnering, Funktionskrav i entreprenader, OPS-modellen och Livscykelmodellen.

\subsubsection{Samverkansentreprenad (Partnering)}

En viktig framgångsfaktor är att förändra roll- och ansvarsfördelningen genom att skapa gemensamma mål och i ett tidigt skede öppet diskutera ekonomi, kvalitet och riskhantering. Kan man åstadkomma detta förändras och förbättras produktionsprocessen.

I samverkansentreprenader är flera deltagare med från starten och utvecklar projektet tillsammans. Ändamålet med samverkan är att skapa ett mervärde genom att effektivisera processerna, förbättra samarbetet och därmed reducera kostnaderna. Mervärdet är både det mätbara dvs. ekonomin både på kort och lång sikt och det mjuka exempelvis nöjda användare och medarbetare. I partnerskapskontraktet fastslås den enskilda deltagarens ansvarsområden och innebär inga väsentliga skillnader mot andra samarbetsformer. Den skillnad som finns består i att alla som gått in i partnerskapskontraktet åtagit sig att hjälpa till att lösa de problem som uppstår. Man har också ett gemensamt ekonomiskt åtagande genom det riktpris som man kommit överens om för projektet. Vid avvikelser fördelas vinster och kostnadsökningar mellan parterna enligt i kontraktet överenskomna proportioner.

Samverkansentreprenader har studerats framförallt i USA och Storbritannien där forskare redovisat kostnadsbesparingar på mellan 2 och $10 \%$ i utvärderade projekt med olika former av samverkansentreprenader. Det har även rapporteras ett markant förbättrat samarbetsklimat, färre tvister och ett ökat kundfokus.

Erfarenheter från dels projekt i Danmark och Norge och dels från demonstrationsprojekt i Sverige har bekräftat de internationella erfarenheterna med bl.a. minskade konflikter, ökad kreativitet och förbättrad erfarenhetsåterföring. 
Under slutet av 2003 utfördes en benchmarking avseende partnering i de nordiska länderna på uppdrag av den nordiska projektgruppen. Syftet var att beskriva samverkansentreprenadkonceptet, sammanställa internationella och nordiska erfarenheter samt identifiera olika entreprenadjuridiska frågor som följer av konceptet. Nedan följer en del av slutsatserna från undersökningen.

Samverkansentreprenader är en process där organisationer utvecklar en mer samverkansinriktad relation istället för att anamma en traditionell partsrelation där beställaren inte har någon dialog med underentreprenörer och konsulten antingen är helt knuten till beställaren vid utförandeentreprenader eller till entreprenören vid totalentreprenader. Traditionella relationer samt relationer vid samverkansentreprenader illustreras i figur 5.3.
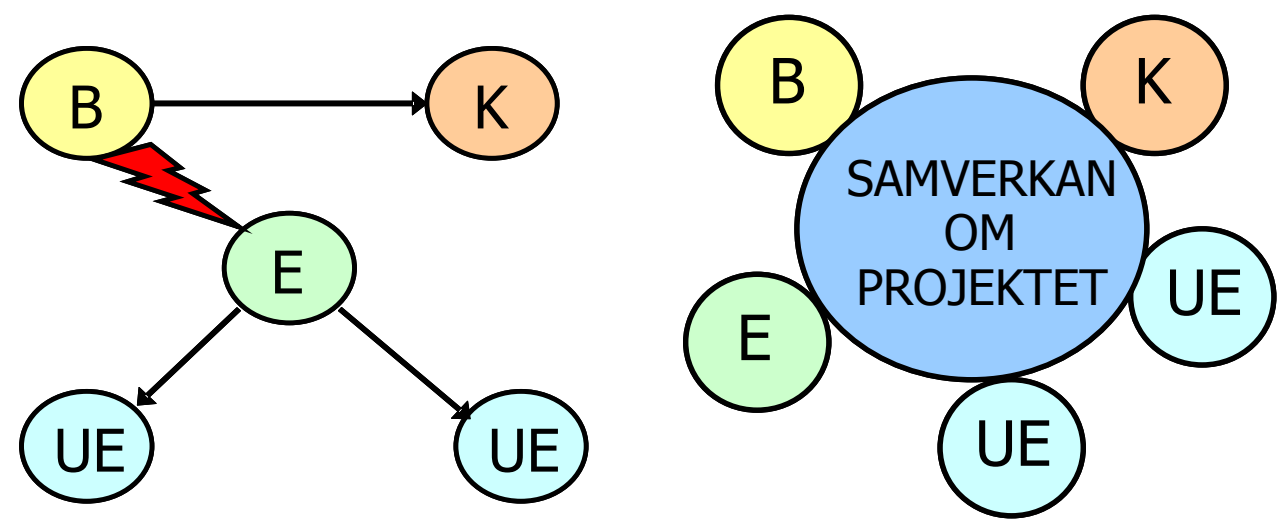

Figur 5.3 Traditionella partsrelationer samt samverkansentreprenad, Beställare, Entreprenör, Projektör och UnderEntreprenör (Olsson).

Processen skall innehålla följande fundament:

- Att parterna gemensamt tar fram ett måldokument för projektet.

- Att ett riktpris har överenskommits för projektet som alla inblandade parter har ett gemensamt ansvar för.

- Att en särskild samverkansgrupp bestående av nyckelpersoner som representerar parterna bildas och arbetar för måluppfyllelse.

- Att nyckelpersonerna medvetet bygger upp respekt och förtroende för respektive roller.

I praktiken innebär samverkansentreprenad att beställaren, entreprenören, viktiga underentreprenörer och projektören bildar en speciell arbetsgrupp för samverkan. Tillsammans utarbetar arbetsgruppen ett måldokument där det 
vanligen ingår både hårda och mjuka delmål. Ett delmål kan vara att tidplanen skall hållas, ett annat är att ändringar och tillägg skall minimeras och ett tredje att krävd kvalitetsnivå skall uppnås. Bland de mjuka delmålen finns alltid ambitionen att skapa ett gott samverkansklimat i gruppen. Dessutom förekommer ofta tidssatta rutiner för att lösa konflikter mellan parterna för att undvika att olösta problem däms upp och blir svåra att hantera. Detta kan utformas som en konfliktlösningstrappa vilket innebär att den operativa ledningen - platschefsnivån - ges en viss tid att komma överens. Om detta misslyckas förs frågan upp till nästa beslutsnivå som i sin tur får en viss tid på sig osv.

I entreprenader där upphandling sker med systemhandlingar som underlag driver arbetsgruppen projekteringen och byggandet i samverkan. Idén är att olika kompetenser skall ges möjlighet att komma till tals vid val av tekniska lösningar, material och utförande. Arbetsgruppen följer också upp sitt eget arbete och korrigerar arbetssätt som inte bidrar till att lösa de mål som medlemmarna arbetar för.

Samverkansentreprenad ska inte ses som en ny entreprenadform utan är ett sätt att organisera och styra (ej kontrollera) samarbetet och kunskapsflödet mellan de involverade i byggprocessen.

Fördelar och framgångsfaktorer med samverkansentreprenad i jämförelse med traditionella former:

- Förbättrar samarbetet/samverkan mellan beställare, entreprenörer, underentreprenörer och konsulter.

- Kostnadseffektiv - undviker kostnadsdrivande ändrings- och tilläggsarbeten.

- Öppnar upp för alternativa lösningar.

- Höjer kvaliteten på slutprodukten.

- Förbättrar den tekniska kunskapsöverföringen.

- Öppen dialog mellan organisationer, i partneringgruppen och mellan individer.

- Beredskap hos nyckelpersoner att acceptera och dela på ansvaret för fel och misstag.

- Ger ett ekonomiskt incitament för delning.

Nackdelar och risker med samverkansentreprenad:

- Antalet möten ökar. 
- Svårare att fastprissätta entreprenaden.

- Risk för att parterna glömmer sina roller.

- Risk att de entrepenadjuridiska konsekvenserna av partnering underskattas.

Samverkansentreprenad kan användas för alla typer av projekt men har störst potential i projekt med stor komplexitet när det råder svårigheter att definiera krav och omfattning, där det finns behov av stor flexibilitet, vid inslag av utveckling, när det är liten eller ingen konkurrens på marknaden och där goda relationer mellan parterna är särskilt betydelsefulla t.ex. vid långa entreprenadtider och stora kontaktytor med slutkunder.

\subsubsection{Funktionskrav i entreprenader}

Ett anläggningsprojekt ska tillfredställa intressenternas krav på funktion. Begreppet krav kan definieras som "en bild av intressenternas behov". Intressentkraven ska sedan översättas till krav på anläggningen eller s.k. systemkrav. Det sker genom att fokus är riktat mot slutprodukten i stället för hur den skall utföras.

Anläggningsprojekt präglas av långa genomförandetider - från första idé till färdig anläggning är tiden vanligen 10 och ibland upp till 30 år. Denna långa tid i kombination med den "upphackade" processen gör att intressenternas krav förändras och individer byts när processen successivt övergår från en fas till en annan. Förändringarna gäller även samhällets värderingar, skiften av politiska beslutsfattare, ändringar i lagstiftning och regelverk osv. När vägen eller järnvägen är klar efter en lång process kan därför kraven vara annorlunda än då projektet började.

Ett sätt att undvika onödiga låsningar i utformningen av anläggningen i tidiga skeden är att arbeta med funktionskrav.

När man byter från användning av kvalitetskrav till funktionella krav och från billigaste anskaffningspris till modeller där man väljer det anbud som är mest fördelaktigt ur driftkostnadssynpunkt är det positivt både för beställaren och för leverantören. Beställaren får lösningar som är förmånligast med hänsyn till helheten och leverantörerna drar nytta av sitt utvecklingsarbete genom en bättre lönsamhet.

Ett försök att utveckla anläggningsprocessen har initierats av IVAs Anläggningsforum i Sverige. På uppdrag av Banverket och Vägverket har Anläggningsforum formulerat ett nationellt program för utveckling inom sektorn. Som underlag för arbetet har Anläggningsforum följt ett antal demonstrationsprojekt inom Banverkets och Vägverkets produktion som bl.a. fokuserat 
på funktionskrav i entreprenader. Erfarenheter av genomförda demonstrationsprojekt är mycket goda och Anläggningsforum lyfter bl.a. fram följande slutsatser:

- Projekten gällande funktionskrav i entreprenader bekräftar vikten av en systematisk hantering av krav med tillhörande kriterier för utvärdering av anbud.

- Användningen av funktionskrav kan ge ökade incitament för såväl teknisk utveckling som kompetensutveckling, men regelverket bör vidareutvecklas och prövas i ytterligare demoprojekt.

Möjligheterna att ställa funktionskrav i en entreprenad för ett investeringsprojekt beror på när i processen entreprenaden handlas upp. För att ställa relevanta funktionskrav bör upphandlingen ske tidigt och innan restriktionerna är så omfattande att entreprenadformen blir en hårt styrd totalentreprenad eller kanske mer är att betrakta som en utförandeentreprenad med ett visst konstruktionsansvar. Vid entreprenader för drift och underhåll är situationen annorlunda och funktionskrav relateras till den drift- och underhållsstandard som entreprenören ska upprätthålla under entreprenadtiden.

Funktionsentreprenaden skapar mer långsiktiga relationer än traditionella entreprenadformer vilket överensstämmer med ett växande intresse för mer utvecklade samverkansformer i byggsektorn. För kompetensutveckling ger långsiktigheten positiva effekter genom bättre förutsättningar för organisatoriskt lärande.

Några generella erfarenheter från de genomförda demonstrationsprojekten med funktionsentreprenader i Sverige är bl.a.:

- Det är inte längre lika viktigt att finna fel i ritningar utan renodlad teknisk problemlösning kommer i fokus.

- Det ökade ansvaret för vägens slutliga funktion skapar ökat engagemang hos entreprenören.

- Ett ökat engagemang som stöds av en ersättningsform med incitament för en bättre kvalitet leder till en bättre kvalitetssäkring hos entreprenören.

- Ett ökat ansvar ställer krav på kompetens hos utförarna vilket också i sin tur leder till att arbetsuppgifterna blir mer intressanta.

\subsubsection{Offentlig Privat Samarbets-kontrakt}

I Norge har man startat tre stora projekt efter den s.k. OPS-modellen. Investeringarna för de tre projekten varierar från cirka $1-2,5$ mrd. norska kronor. Projekten avser nybyggnation av vägar från 17 till $30 \mathrm{~km}$ längd. För 
demoprojekten har det utvecklats en modell där privata aktörer konkurrerar om ett kontrakt med ansvar för projektering, byggnation och finansiering av vägen samt ansvar för drift och underhåll under en 25-årsperiod. OPSorganisationen får utbetalningar av medel efter en betalningsmekanism med fyra betalningselement där det största beloppet är knutet till vägens öppnande. Under drift- och underhållsperioden finns möjligheter att få en trafiksäkerhetsbonus knuten till olyckshändelser på vägen och det finns även kompensation för ökat slitage i förhållande till förväntad prognos.

Vegvesenet i Norge har tillsammans med juridiska och finansiella rådgivare utvecklat kontrakt och upphandlingsprocess som grundar sig på internationella erfarenheter och regelverk, men som är förankrad i norsk vägbyggnadsteknik och kontraktstradition.

I Finland har motsvarande former prövats under benämningen PPP (public private partnership), vilket också diskuteras i Danmark och Sverige.

\subsubsection{Målpriskontrakt}

Målpriskontrakt är i princip ett enhetspriskontrakt med incitamentsavtal där riskerna fördelas med avseende på avtalat målpris. Entreprenören tas med in i projekteringsskedet och ett målpris fastställs och regleras efter en formel. Beställaren och utföraren delar jämnlikt på eventuell vinst.

I Norge har man efter projekt med målpriskontrakt gjort följande iakttagelser:

- "Konkurrensen" mellan entreprenör och byggherre försvann i och med att kontraktet blev undertecknat.

- En stor öppenhet mellan entreprenör och byggherre avseende priser och kalkylunderlag.

- Det var ointressant vem som initierade kostnadsreducering.

- Det var minimalt med formell korrespondens mellan parterna.

- Drivkraften för entreprenören var att kunna påverka vinsten genom konstruktivt samarbete.

- För entreprenören blev tiden för anbudsräkning och projektering något längre än vid ett traditionellt anbudsförfarande.

Erfarenheterna från Norge tyder på att denna kontraktsmodell är intressant varför formen prövas och vidarutvecklas i fler projekt. 


\subsubsection{Livscykelmodell}

Generellt livscykeltänkande omfattar tidsperioden från köp av råmaterial för framställning av produkten till slutdeponering av restprodukter. I sitt största omfång omfattar livscykelbegreppet beställarens och slutanvändarnas (väganvändarnas) kostnader över hela livscykeln samt produktens miljöpåverkan.

I Finland bygger inriktningen i Vägförvaltningens nya upphandlingsstrategi på livscykelansvar. När livscykelansvaret införs optimeras väghållarens kostnader för byggande och underhåll och ska även täcka trafikkostnader och miljöpåverkan. Beställaren ställer främst upp funktionella krav och utföraren ges stora möjligheter till innovationer och optimering av underhållet. Avtalsperioden för modellen är på $20-30$ år.

Livslängden hos olika delar av en väg varierar från några år till över 100 år. Ofta åldras en konstruktion dessutom funktionellt före den tekniska livslängdens slut. Ett sådant exempel är livslängden för broar och utvecklingen av största tillåtna fordonsvikter och fordonsstorlekar från 1970-talet till nutid. Det föreslagna livscykelavtalet på 20-30 år är en lång tid i jämförelse med nuvarande upphandlingspraxis men representerar ändå bara en del av den verkliga livslängden. Enligt internationell praxis bestäms en minimikvalitet för konstruktioner vid livscykelavtalets utgång.

I små projekt som t.ex. avser underhållsarbeten används inte livscykelmodellen utan man pratar i stället om livslängd för utförda arbeten. Modellen har utvecklats längst i pilotarbeten avseende beläggningsarbeten, där första livslängdskriteriet har varit spårbildning. Leverantören har gett anbud på sin beläggningslösning samt meddelat pris och livslängd, under vilken spårbildningen hålls inom givna ramar. Den leverantör som gett de billigaste årskostnaderna vann. Spårbildningens utveckling kontrolleras med mätningar efter 3-5 år och livslängdens totala spårbildning prognostiseras mha. livslängdsmodellen. Detta resulterar i bonus eller värdeminskning för leverantören.

Inom banhållningen passar livscykelmodellen bäst för byggandet av nya bansträckor och systemleveranser. Banförvaltningscentralen i Finland har i några fall prövat att ta hänsyn till livscykelkostnader $\mathrm{i}$ anbudsjämförelsen. Däremot har inte livscykelmodellen använts i samband med långvariga byggnadsprojekt som även innehållit underhållsplikt. 


\section{7 Övrigt}

\section{Beskattning}

Många olika beskattningsregler gäller för en utförare när verksamhet flyttas över gränserna. Olägenheterna konkretiseras när leverantören använder egen personal och egna maskiner och framför allt när det handlar om mindre uppdrag eller specialentreprenader. Om t.ex. ett utländskt företag har med sig utrustning in till Norge måste företaget betala $25 \%$ av utrustningens värde i tullavgift. Denna avgift återbetalas med ett avdrag på $5 \%$ per månad vid utresa. Vid en månads arbete får man tillbaka $20 \%$, vid tre månader $15 \%$ osv.

\section{Fackliga frågor}

I Sverige måste man upprätta avtal med SEKO och betala avgifter oavsett om man har svensk arbetskraft eller inte och gynnar givetvis inte intresset att verka på en nordisk marknad.

\section{Löner}

Löneskillnaderna i de nordiska länderna varierar. I Norge är exempelvis lönerna $20 \%$ högre än i Sverige vilket innebär att de norska bolagens konkurrenskraft på marknaden är kraftigt reducerad.

\section{Valuta}

Olika valutor medför även skillnader i kostnadsnivåerna i de nordiska länderna.

\section{IT-verktyg}

I de nordiska länderna är kunskapen om informations- och kommunikationsteknik mycket hög och är en kunskap som man borde utnyttja bättre inom anläggningsbranschen. Den finska teknologiska utvecklingscentralen TEKES har genomfört ett framgångsrikt projekt om byggnadsprocessens möjligheter att utnyttja informationsnät under hela processen. Inom anläggningsbranschen skulle man säkert kunna nyttja projektets resultat.

Ett utnyttjande av IT-teknologi i full skala skulle kräva en gemensam datamodell. Denna skulle möjliggöra kompatibla projekteringsprogram och en snabb och felfri dataöverföring. Dessutom skulle data kunna lagras på ett pålitligt sätt under projektets hela livscykel.

\section{Kulturskillnader}

Det finns många hinder för en gemensam anläggningsmarknad och inte minst de kulturella skillnader som finns mellan länderna. På grund av den 
geografiska närheten och likheten i språk är det lätt att förbise de skillnader som ändå finns. Skillnader finns exempelvis i sättet att arbeta, i anbud, i förhandlingar, i avtal m.m.

Förutom språk- och terminologiproblem kan olika parters förutfattade meningar vara ett hinder. Beställarna måste behandla alla anbud likvärdigt så att inhemska entreprenörer inte får bättre möjligheter än vad andra får. De nationella aktörerna kan känna sig hotade när de andra entreprenörerna vinner ett anbud. Nya aktörer skall kunna lita på andra aktörer inom branschen och skall opartiskt kunna sluta avtal med alla huvud- och underentreprenörer inom branschen. I den här frågan spelar de etiska spelreglerna en mycket stor roll.

\section{Materialteknologiutveckling}

En tänkbar möjlighet för att begränsa vissa insatsvarors betydelse är att utveckla materialteknologin och i större omfattning använda restprodukter eller sämre material. De globala miljöavtalen förutsätter att man reducerar användningen av naturtillgångar såväl lokalt, nationellt som globalt. Materialteknologins utveckling har också gjort det möjligt att ersätta traditionella materialkonstruktioner med konstruktioner byggda av återvunna material. Den nya tekniken har prövats på ett flertal ställen i Finland. Olika instanser har undersökt över 200 olika industriella "avfalls" lämplighet som byggnadsmaterial. Den nya materialteknologins genombrott förutsätter fortfarande att byggnads- och miljötekniska undersökningar utförs, men framförallt beställarorganisationernas stöd för att förverkliga nationellt ingångna förbindelser att följa de globala avtalen. Ett lämpligt mål för de närmaste åren vore, att teknologin för bruk av återvunna material vidareutvecklas och att man på så sätt kan minska användningen av naturstensmaterial. 


\section{$6 \quad$ Handlingsplan}

\subsection{Allmänt}

Det nu genomförda projektarbetet beskriver en lång rad av åtgärder som kan genomföras för att ge bättre förutsättningar för en utvecklad gemensam nordisk anläggningsmarknad och som är av såväl politisk, branschgemensam som verksintern karaktär. Utvecklingsmöjligheterna är mycket goda men samtidigt handlar det om att bryta gamla invanda traditioner och som kommer att kräva mycket arbete, stort engagemang och en från alla inblandade parter tydligt markerad viljeinriktning.

För att nå den önskade marknadsutvecklingen ges i bilaga 4 förslag på ett antal gemensamma nordiska utvecklingsområden redovisade i tabellform som utgår ifrån den genomförda beskrivningen och analysen. I kapitel 6.2 presenteras en handlingsplan där några av de förslagna områdena prioriterats för ett fortsatt arbete under den närmaste tiden.

\subsection{Prioriterade utvecklingsprojekt}

Av de föreslagna utvecklingssområdena redovisas i tabell 6.1 de utvecklingsprojekt som bedöms som viktigast. Projekt markerade med asterix (*) har prioriterats i samråd med verkens ledningar vid ett gemensamt möte den 16 mars 2004.

För det fortsatta arbetet kommer förslag till mer detaljerade projektbeskrivningar att tas fram med ytterligare konkretisering av respektive projekts syfte och mål samt genomförandeform.

I förteckningen har för varje utvecklingsprojekt angivits vilken organisation och vilket land som ansvarar för respektive projektbeskrivning. Samtliga beskrivningar ska diskuteras och godkännas i den styrgrupp som verkens ledningar utser. Styrgruppen skall också ansvara för att de prioriterade projekten genomförs.

En del av de föreslagna utvecklingsprojekten berör områden utanför verkens verksamhetsområden. Den fortsatta hanteringen av dessa bör därför ske på departementsnivå via Nordiska Ministerrådet.

I arbetet med samtliga prioriterade projekt ingår att beskriva EU-gemensamma regler som berör det aktuella området. 
För de projekt där såväl väg- som järnvägssidan bör delta har ansvarig organisation markerats med understyrkning.

Den nordiska visionen avseende den framtida leverantörsmarknaden skall finnas framme för godkännande senast under oktober månad 2004 då även övriga projektbeskrivningar inom verkens ansvarsområden ska vara klara.

\section{Tabell 6.1 Prioriterade utvecklingsprojekt fördelad på ansvarig organisa-}

\section{tion.}

\begin{tabular}{|c|c|c|}
\hline $\begin{array}{c}\text { Prioriterade } \\
\text { Utvecklingsprojekt }\end{array}$ & $\begin{array}{c}\text { Ansvarig } \\
\text { organisation } \\
\end{array}$ & $\begin{array}{c}\text { Ansvarig } \\
\text { nation } \\
\end{array}$ \\
\hline Gemensam databas för anslag och planer & Vejdirektoratet & Danmark \\
\hline Gemensam databas för ordlista & $\begin{array}{l}\text { Vägförvaltningen } \\
\text { Banförvaltningscentralen }\end{array}$ & Finland \\
\hline $\begin{array}{c}\text { Gemensamma krav avseende hälsa, miljö och } \\
\text { säkerhet (HMS) * }\end{array}$ & $\frac{\text { Statens vegvesen }}{\text { Jernbaneverket }}$ & Norge \\
\hline $\begin{array}{l}\text { Gemensamma spårtekniska och säkerhetsmässi- } \\
\text { ga krav på maskiner vid järnvägsbyggande * }\end{array}$ & $\frac{\text { Jernbaneverket }}{\text { Banverket }}$ & $\begin{array}{l}\text { Norge } \\
\text { Sverige }\end{array}$ \\
\hline Enhetliga kompetenskrav & $\frac{\text { Banverket }}{\text { Vägverket }}$ & Sverige \\
\hline $\begin{array}{c}\text { Nordisk vision avseende den framtida leveran- } \\
\text { törsmarknaden * }\end{array}$ & $\frac{\text { Vägverket }}{\text { Banverket }}$ & Sverige \\
\hline $\begin{array}{l}\text { Utveckla entreprenadformer och alternativa } \\
\text { samarbetsformer * }\end{array}$ & Vägförvaltningen & Finland \\
\hline Utveckling av funktionskrav * & Statens vegvesen & Norge \\
\hline Översyn av beskattningsregler & Nordisk Ministerråd & - \\
\hline Översyn av konkurrenshämmande avtal & Nordisk Ministerråd & - \\
\hline
\end{tabular}

* Prioriterade utvecklingsprojekt i samråd med verkens ledningar den 16 mars 2004. 


\subsubsection{Gemensam marknadsplats}

\section{Gemensam databas för anslag och planer}

Projektinriktning:

För bättre spridning av information till de nationella, nordiska och internationella leverantörsmarknaderna och för att öka kunskapen om aktuella projekt på såväl lång som kort sikt bör en gemensam databas utvecklas över trafikverkens långsiktiga planer för investeringar, drift och underhåll samt aktuella förfrågningsunderlag. Nuvarande informationsmedier skall i möjligaste mån användas.

Ansvarig organisation: Vejdirektoratet i Danmark

\section{Gemensam databas för ordlista}

Projektinriktning:

En gemensam ordlista för den nordiska anläggningsbranschen bör tas fram. Ordlistan ska innefatta tekniska begrepp och benämningar på de fyra nordiska språken samt engelska så att databasen även kan bli en plattform för den övriga internationella marknaden.

Ansvarig organisation: Vägförvaltningen och Banförvaltningscentralen i Finland

\subsubsection{Verka för gemensamma föreskrifter och bestämmelser}

\section{Gemensamma krav avseende hälsa, miljö och säkerhet (HMS)}

Projektinriktning:

Det är av stor betydelse att HMS ingår som en del i en organisation och dess arbetsutförande så att skador och olyckor undviks, liksom att val av arbetsmetoder och utrustning minimerar risken för förslitningsskador.

I projeketet har det framkommit att HMS hanteras och värderas olika i de nordiska länderna. För en bättre fungerande nordisk anläggningsmarknad är det därför viktigt att ta fram gemensam praxis och enhetliga krav för frågor kring hälsa, miljö och säkerhet, vilka kan riktas både till beställare och till utförare.

Ansvarig organisation: Statens vegvesen och Jernbaneverket i Norge 


\section{Gemensamma spårtekniska och säkerhetsmässiga krav på maskiner vid järnvägsbyggande}

Projektinriktning:

För att skapa bättre förutsättningar för en nordisk anläggningsmarknad inom det järnvägstekniska området bör gemensamma regler skapas för exempelvis godkännande av spårtekniska och säkerhetsmässiga krav på maskiner. Vidare bör det vara en likvärdig godkännandeprocedur och att respektive land accepterar godkännande från ett annat nordiskt land.

Ansvarig organisation: Jernbaneverket i Norge och Banverket i Sverige

\section{Enhetliga kompetenskrav}

Projektinriktning:

Många av de nordiska väg- och banverken har egna krav på olika utbildningar och kurser som personalen på en arbetsplats måste ha genomgått. För att t.ex. få arbeta på en vägarbetsplats i Sverige måste alla ha genomgått kursen "Arbete på väg" och i Finland kursen Vägskälet (Tieturva). På järnvägssidan finns ett flertal liknande exempel.

En samordning av dessa obligatoriska kurser och utbildningar borde kunna ske så att en godkänd kurs i ett land också är godkänd i de övriga.

Ansvarig organisation: Banverket och Vägverket i Sverige

\subsubsection{Utveckling av upphandlingsprocessen}

\section{Nordisk vision avseende den framtida leverantörsmarknaden}

Projektinriktning:

Att skapa bättre förutsättningar för en utvecklad gemensam nordisk anläggningsmarknad är ett strategiskt beslut som varje beställarorganisation bör ta hänsyn till och utformas så att man kan se en tydlig skillnad mellan den nuvarande situationen och den situationen man vill uppnå.

Upphandlingsstrategierna mellan de nordiska länderna skiljer sig idag markant. En gemensam vision för leverantörsmarknaden skulle främja den fortsatta utvecklingen och avspegla viljan från verken att skapa rätt förutsättningar för en öppnare marknad och underlätta för utförarna att röra sig över gränserna. Dessutom skulle de nordiska länderna få bättre möjligheter att gemensamt påverka regler, förordningar och direktiv som ställs inom EU.

Ansvarig organisation: Vägverket och Banverket i Sverige 


\subsubsection{Utveckling av nya samarbetsformer}

\section{Utveckla entreprenadformer och alternativa samarbetsformer.}

Projektinriktning:

En viktig framgångsfaktor för anläggningsmarknaden i Norden är att skapa gemensamma mål och alternativa former för roll- och riskfördelningen mellan parterna. För att möjliggöra en sådan utveckling behöver modeller tas fram och prövas för alternativa former av samarbete och riskfördelning och erfarenheterna kommuniceras och diskuteras inom de nordiska länderna.

Ansvarig organisation: Vägförvaltningen i Finland

\section{Utveckling av funktionskrav}

Projektinriktning:

Erfarenheterna från genomförda funktionsentreprenader i Norden är att entreprenadformen skapar positiva effekter för ökad fokusering på tekniska problemlösningar, ökat utföraransvar och engagemang för slutproduktens funktion med bättre kvalitetssäkring samt en positiv kompetensutveckling.

För att utveckla entreprenadformen behöver dock förmågan att uttrycka och använda väg- och järnvägsbehov i funktionstermer förbättras liksom en systematisk hantering av krav med tillhörande kriterier för utvärdering av anbud. Genom projektarbetet ska nuvarande kunskaper sammanställas, utvecklingsbehoven klarläggas och prioriteras och erfarenheterna kommuniceras mellan de nordiska länderna.

Ansvarig organisation: Statens vegvesen i Norge

\subsection{5 Övriga utvecklingsmöjligheter}

\section{Översyn av beskattningsregler}

Projektinriktning:

Många olika beskattningsregler gäller för en utförare när verksamhet flyttas över gränserna. Olägenheterna konkretiseras när leverantören använder egen personal och egna maskiner. Detta gynnar inte möjligheten för aktörer att verka på en nordisk marknad. De beskattningsregler som hämmar en naturlig rörlighet över de nordiska nationsgränserna bör därför ses över.

Ansvarig organisation: Nordiska Ministerrådet 


\section{Översyn av konkurrenshämmande avtal}

Projektinriktning:

I Sverige måste man upprätta avtal med SEKO och betala avgifter oavsett om man har svensk arbetskraft eller inte och gynnar givetvis inte intresset att verka på en nordisk marknad. Inriktningen borde vara att se över konkurrenshämmande avtal som hindrar en naturlig rörlighet över gränserna.

Ansvarig organisation: Nordiska Ministerrådet 


\section{$7 \quad$ Referenser}

\section{Rapporter}

Banestyrelsen (2003). Arsrapport 2002 for Banestyrelsen, Banestyrelsen, København Ø

Banförvaltningscentralen (2003). Arsberättelse 2002, Erweko Oy, Helsinki

Banverket (2003). Årsredovisning 2002, Banverket, Borlänge

Byggkommisionen (2002). Skärpning gubbar! - Betänkande av Byggkommisionen, SOU 2002:115, Fritzes Offentliga publikationer, Stockholm (ISBN 91-38-21807-0)

Bergström, M., Malmtorp, J., Nylén, K-O. och Rosengren, L. (2003). Framgångsfaktorer i bergbyggandet, Banverket, Borlänge

Økonomiafdelingen, Vejdirektoratet (2003). Arsrapport 2003, Vejdirektoratet, København K (ISBN 87-7923-588-3)

Jernbaneverket (2003). Arsmelding 2002, Jernbaneverket, Oslo

Karlsson P., Redtzer L. (2000). Utvecklingsstrategi för Banverkets produktionsverksamhet - Förutsättningar och strategier för konkurrensutsättning av Banverkets produktionsverksamhet, Banverket

Kungl. Ingenjörsvetenskapsakademien IVA (2003). Demonstrationsprojekt för utveckling av anläggningsprocessen, Grafiska Produkter, Stockholm (ISBN 91-7082-702-8)

Kungl. Ingenjörsvetenskapsakademien IVA (2002). Samverkan för utveckling inom anläggningssektorn - förslag till nationellt program

NVF - Finska avdelningen av utskott 31 (2000). Vägbyggnadsupphandling $i$ Finland

NVF - Utskott 31 Finland (2002). Statusrapport 2000-2002

Olsson, U. (2004). Partnering - Konceptets innebörd, tillämpning samt diskussion om vilka entreprenadjuridiska frågor som uppkommer, Banverket, Luleå

Ranta-Aho, A. (2003). Upphandling av väginvesteringar inom de nordiska länderna, Vägförvaltningen, Tammerfors 
SINTEF (2004). Drift og vedlikehold av vegnettet $i$ grensetraktene, Trondheim

Statens vegvesen (2003). Arsmelding 2002, Statens vegvesen, Oslo

Vägförvaltningen (2003). Vägförvaltningen Arsberättelse 2002, Forssan Kirjapaino Oy, Helsinki (ISBN 951-803-087-1)

Vägförvaltningen (2003). Upphandlingsstrategi för väghållningen, Vägförvaltningen, Helsingfors (ISBN 951-803-012-X)

Vägförvaltningen (2003). Vägfakta 2003, Vägförvaltningen, Tammerfors

Vägverket (2003). Årsredovisning 2002, Publikation 2003:35, Vägverket, Borlänge (ISSN 1401-9612)

\section{Tidskrifter}

Abrahamsson, P. (2003). Byggsektorns förnyelsebehov, Vbyggaren - Medlemstidning för SVR, 2 (16), 4-5

Apleberger, L. (2003). Byggsektorns förnyelsebehov, Vbyggaren - Medlemstidning för SVR, 5 (16), 4-5

Arhippainen, M. (2003). Det gränslösa Norden alltjämnt bara en dröm, Hufvudstadsbladet, 30 oktober 2003, 14

Bäckström, S. (2002). Partneringsprojekt i Norsjö - Samarbete ger engagemang och en smidigare väghållning, På Väg, 7 (7), 13

Bergström, C. (2004). Ledningens syn på säkerhet smittar av sig, På Väg, 3 (7), 13

Etikgruppen (2003). Nya etiska regler för SVR-medlemmar, Vbyggaren Medlemstidning för SVR, 4 (16), 4-7

Jacobsson, C. (2004). Satsningar på vägar gynnar utländska byggare, Dagens Nyheter, 19 februari 2004, 2

Källgård, Å. (2003). Forskning ska ge ett nytt bränsle till anläggningsbran-

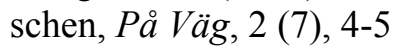

Källgård, Å. (2003). Spännande och tuffa tider väntar anläggningsbranschen, $P a ̊$ Väg, 2 (7), 6

Källgård, Å. (2003). Så här sköts vägarna i Norden, På Väg, 3 (7), 5-9

Liljas, S. (2002). En bolagisering skulle bädda för en sundare konkurrens, $P a ̊$ Väg, 7 (7), 15 
Söderlind, L. (2003). Byggsektorns förnyelsebehov, Vbyggaren - Medlemstidning för SVR, 9 (16), 4-5

\section{Arbetsmaterial - Nationella arbetsgrupper}

Banförvaltningscentralen (2003). Banhållningens marknader $i$ Finland, Jaakko Pöyry infra

Banförvaltningscentralen (2003). Nationella arbetsuppgifter Aktivitet 2 Finland Järnväg, Jaakko Pöyry infra

Banförvaltningscentralen (2003). Nationella arbetsuppgifter Aktivitet 3 Finland Järnväg, Jaakko Pöyry infra

Banverket (2003). Kartläggning av den nordiska anläggningsmarknaden, Redtzer, L.

Statens vegvesen (2004). Gemensam nordisk entreprenadmarknad och nordiska upphandlingsformer - Protokoll Seminarie 2 i Norge, Hillestad. Å.

Vegdirektoratet (2003). Anleggmarkedet i Norge, Selnes, B.

Vegdirektoratet (2004). Felles nordisk entreprenørmarked og felles anskaffelsesformer, Selnes, B.

Vejdirektoratet (2003). Gemensam nordisk entreprenadmarknad och nordiska upphandlingsformer Aktivitet 2, Simonsen, P.

Vägförvaltningen (2003). Nationella uppgifter - Aktivitet 1. Finland/Väg, Pukkila. M.

Vägförvaltningen (2003). Gemensam nordisk entreprenadmarknad och nordiska upphandlingsformer - Aktivitet 2, Pukkila. M.

Vägförvaltningen (2003). Gemensam nordisk entreprenadmarknad och nordiska upphandlingsformer - Protokoll Seminarie 1 i Finland, Ranta-Aho. A.

Vägförvaltningen (2004). Gemensam nordisk entreprenadmarknad och nordiska upphandlingsformer, Nationella arbetsuppgifter - Aktivitet 3 Finland, väg, Pukkila. M.

Vägverket (2003). Nationella arbetsuppgifter Aktivitet 1 kartläggning av den nordiska anläggningsmarknaden Sverige-Väg, Dittlau P.

Vägverket (2003). Nationella arbetsuppgifter Aktivitet 2 - Väg- och Banverk, Dittlau P. 


\section{Bilaga 1}

Nedan följer en sammanställning av deltagarna i de olika grupper som ingått i projektet.

\section{Nordisk projektgrupp:}

- Tom Ramstedt

- Nils-Erik Schmidt

- Per Simonsen

- Bjørn Erik Selnes

- Jan Vidar Moen

- Rolf Kr. Jelstad

- Mauri Pukkila

- Juha-Heikki Pasanen

- Peter Dittlau

- Lars Redtzer
Vägverket

Vägverket

Vejdirektoratet

Statens vegvesen

Jernbaneverket

Jernbaneverket

Tiehallinto

Ratahallintokeskus

Vägverket

Banverket

Sverige
Sverige
Danmark
Norge
Norge
Norge
Finland
Finland
Sverige
Sverige

(Ordförande)

(Bitr. ordförande)

Danmark

Norge

Norge

Finland

Sverige

(Projektledare)

(Bitr. projektledare)

\section{Arbetande utskott inom nordisk projektgrupp:}

- Lars Redtzer

- Nils-Erik Schmidt

- Peter Dittlau
Banverket

Vägverket

Vägverket
Sverige

Sverige

Sverige

\section{Nationella arbetsgrupper:}

Nationell arbetsgrupp Danmark - väg:

$\begin{array}{lll}\text { - Per Simonsen } & \text { Vejdirektoratet } \\ \text { - } \quad \text { Bo Tarp } & \text { Vejdirektoratet } \\ \text { - } & \text { Claus Nødgaard Hansen } & \text { Vejdirektoratet }\end{array}$

(Ordförande) 
Nationell arbetsgrupp Finland - väg:

- Markku Teppo

- Jussi Ala-Fossi

- Pär-Håkan Appel

- Jaakko Heikkilä

- Pekka Jokela

- Timo Kohtamäki

- $\quad$ Anders Nordström

- Mauri Pukkila
Vägförvaltningen

Vägförvaltningen

Vägförvaltningen

SCC Viatek AB

Vägförvaltningen

Lemcon AB

Vägaffärsverket

Tiehallinto

Nationell arbetsgrupp Finland - jvg:

- Juha-Heikki Pasanen

Ratahallintokeskus

- Kari Ruohonen

Ratahallintokeskus

- Pasi Aarnio

VR-Rata

- Harri Lukkarinen

JP-Terasto

\section{Nationell arbetsgrupp Norge - väg/jvg:}

- Bjørn Erik Selnes

- Gisle Fossberg

- Erik Norstrøm

- Rolf Kr. Jelstad

- Jan Vidar Moen

Nationell arbetsgrupp Sverig - väg/jvg:

- Tom Ramstedt

Vägverket

Vägverket

Nils-Erik Schmid

- Per Björnfot

Vägverket

Vägverket

Vägverket Prod.

Vägverket Prod.

Vägverket Prod

Banverket
(Ordförande)

(Ordförande)

(Sekreterare)

(Ordförande)

(Ordförande)

(Bitr. ordförande) 


\section{Följegrupp:}

Departementen i de nordiska länderna har utgjort projektets följegrupp, följande personer har ingått i följegruppen:

\begin{tabular}{|c|c|c|}
\hline - $\quad$ Tomas Brolin & Näringsdepartementet & Sverige \\
\hline Erik Toft & Trafikministeriet & Danmark \\
\hline Juhani Tervala & Kommunikationsministeriet & Finland \\
\hline - $\quad$ Mikko Ojajärvi & Kommunikationsministeriet & Finland \\
\hline Elisabeth Classon & Samferdelsdepartementet & Norge \\
\hline Ole Tollefsen & Samferdelsdepartementet & Norge \\
\hline
\end{tabular}

\section{Seminarium - deltagarlista:}

För att få in synpunkter från branschen har två seminarier genomförts. Nedan följer en sammanställning av de beställare och utförare som varit representerade vid seminarierna:

$\begin{array}{ll}\text { Beställare: } & \text { - } \quad \text { Vejdirektoratet } \\ \text { - } & \text { Banförvaltningscentralen } \\ \text { - } & \text { Kommunikationsministeriet } \\ \text { - } & \text { Vägförvaltningen } \\ \text { - } & \text { Statens Vegvesen } \\ \text { - } & \text { Jernbaneverket } \\ \text { - } & \text { Vägverket } \\ \text { - } & \text { Banverket } \\ \text { Branschorganisationer: } \\ \text { - } \quad \text { Finlands Schaktentr.förbund } \\ \text { - } \quad \text { TEKES } \\ \text { - } \quad \text { Maskinentrepr. Forbund MEF } \\ \text { - } \quad \text { EBA } \\ \text { - } \quad \text { RIF } \\ \text { - } \quad \text { ATI } \\ \text { - } \quad \text { Sveriges Byggindustrier } \\ \text { Entreprenörer: } \\ \text { - } \quad \text { JP-Terasto Oy } \\ \text { - } \quad \text { JP-Transplan Oy } \\ \text { - } \quad \text { VR-Räa } \\ \text { - Vägaffärsverket }\end{array}$

\begin{tabular}{llll} 
& \multicolumn{2}{l}{ Entreprenörer: } & \\
Danmark & - & Lemcon Oy & Finland \\
Finland & - & Baneservice & Norge \\
Finland & - & Mesta & Norge \\
Finland & - & Skanska & Norge \\
Norge & - & Veidekke & Norge \\
Norge & - & Reinetsen Anlegg & Norge \\
Sverige & - & NCC & Norge \\
Sverige & - & Magne Nærum & Norge \\
& - & Repstad Anlegg & Norge \\
Finland & - & Skanska & Sverige \\
Finland & - & Vägverket Produktion & Sverige \\
Norge & - & Banverket Produktion & Sverige \\
Norge & - & Peab & Sverige \\
Norge & Konsulter: & \\
Norge & - & EMCON A/S & Danmark \\
Sverige & - & VTT & Finland \\
& - & Hjellnes COWI & Norge \\
Finland & - & Norconsult & Norge \\
Finland & - & Vianova & Norge \\
Finland & - & Sweco & Norge \\
Finland & & &
\end{tabular}




\section{Bilaga 2}

Nordisk jämförelse avseende volymer år 2002 samt en jämförelse av planeringsramar 2003-2012 för statlig väg- och banhållning.

\section{Allmänt}

\begin{tabular}{lcccc}
\hline & Danmark & Finland & Norge & Sverige \\
\hline Areal $1000 \mathrm{~km}^{2}$ & 43 & 338 & 324 & 450 \\
Befolkning milj. Inv. & 5,3 & 5,1 & 4,5 & 8,9 \\
\hline
\end{tabular}

\section{Vägnätet 2002}

\begin{tabular}{|c|c|c|c|c|}
\hline & Danmark $^{1}$ & Finland & Norge & Sverige \\
\hline Statliga vägar, km & 11583 & 78100 & 26964 & 98200 \\
\hline Europaväg & 956 & - & - & 4900 \\
\hline Riksväg & 662 & - & - & 10500 \\
\hline Länsväg & 9965 & - & - & 82800 \\
\hline Enskilda vägar, km & - & - & 90000 & 284000 \\
\hline Statsbidrag & - & - & - & 74100 \\
\hline Övriga & - & - & - & 210000 \\
\hline Fylkesveger, km & - & - & 27162 & - \\
\hline Kommunala vägar, km & 60325 & 115000 & 37726 & 40000 \\
\hline Statlig väghållning, milj. $€^{2}$ & 235 & 1282 & 1792 & 1785 \\
\hline Investering & 157 & 570 & 969 & 920 \\
\hline Drift och underhåll & 78 & 712 & 823 & 865 \\
\hline
\end{tabular}

${ }^{1}$ Uppgifter från Danmark är från 2001.

$21 \mathrm{EUR}=7,43 \mathrm{DKK}=8,20 \mathrm{NOK}=8,95 \mathrm{SEK}$ 
Järnvägsnätet 2002

\begin{tabular}{lcccc}
\hline & Danmark & Finland & Norge & Sverige \\
\hline Statliga järnvägar, km & 2300 & 5850 & 4077 & 14000 \\
$\quad$ Stomjärnvägar & - & - & 4077 & 11800 \\
Övriga järnvägar & - & - & - & 2200 \\
& - & 265 & 556 & 839 \\
Statlig banhållning, milj. $€^{2}$ & - & 135 & 170 & 477 \\
...Investering & - & 130 & 386 & 362 \\
Drift och underhåll inkl. reinvest. & & & & \\
\hline
\end{tabular}

${ }^{1}$ Uppgifter från Danmark är från 2001.

${ }^{2} 1 \mathrm{EUR}=7,43 \mathrm{DKK}=8,20 \mathrm{NOK}=8,95 \mathrm{SEK}$

\section{Planeringsram Danmark}

\begin{tabular}{|c|c|c|c|c|}
\hline \multirow[t]{2}{*}{ Danmark } & & \multicolumn{3}{|c|}{ Planeringsram } \\
\hline & & 2003 & 2004 & 2007 \\
\hline Årlig volym investering & $\mathrm{M} €$ & & & \\
\hline Järnväg (statliga) & & - & - & - \\
\hline Väg (statliga) & & 158 & 171 & 150 \\
\hline Ârlig volym drift och underhåll & $\mathrm{M} €$ & & & \\
\hline Järnväg (statliga) & & - & - & - \\
\hline Väg (statliga) & & 82 & 91 & 82 \\
\hline Drift och underhåll, uppdelad - väg & $\mathrm{M} €$ & & & \\
\hline Vintervägsunderhåll & & 10 & 10 & 10 \\
\hline Beläggningsunderhåll & & 15 & 14 & 15 \\
\hline Grusvägsunderhåll & & - & - & - \\
\hline Bro- och tunnelunderhåll & & 32 & 32 & 33 \\
\hline Vägutrustning & & 3 & 3 & 3 \\
\hline Färjedrift & & - & - & - \\
\hline
\end{tabular}

\section{Planeringsram Norge}

\begin{tabular}{|c|c|c|c|c|}
\hline \multirow[t]{2}{*}{ Norge } & & \multicolumn{3}{|c|}{ Planeringsram } \\
\hline & & 2003 & 2004 & 2012 \\
\hline Årlig volym investering & $\mathrm{M} €$ & & & \\
\hline Järnväg (statliga) & & 174 & 228 & 165 \\
\hline Väg (statliga) & & 969 & 1079 & 896 \\
\hline Årlig volym drift och underhåll & M€ & & & \\
\hline Järnväg (statliga) & & 377 & 359 & 366 \\
\hline Väg (statliga) & & 500 & 500 & - \\
\hline Drift och underhåll, uppdelad - väg & $\mathrm{M} €$ & & & \\
\hline Vintervägsunderhåll & & 156 & - & - \\
\hline Beläggningsunderhåll & & 130 & - & - \\
\hline Grusvägsunderhåll & & 2 & - & - \\
\hline Bro- och tunnelunderhåll & & 65 & - & - \\
\hline Vägutrustning & & 123 & - & - \\
\hline Färjedrift & & 134 & - & - \\
\hline
\end{tabular}




\section{Planeringsram Finland}

\begin{tabular}{lcrrr}
\hline Finland & \multicolumn{4}{c}{ Planeringsram } \\
\hline & $M €$ & $\mathbf{2 0 0 3}$ & $\mathbf{2 0 0 4}$ & $\mathbf{2 0 1 2}$ \\
\hline Árlig volym investering & & 255 & 257 & 200 \\
Järnväg (statliga) & & 570 & 530 & 645 \\
Väg (statliga) & $M €$ & & & \\
Ârlig volym drift och underhåll & & & \\
Järnväg (statliga) & & 200 & 215 & 185 \\
Väg (statliga och kommunala) & & 712 & 708 & 730 \\
& $M €$ & & & \\
Drift och underhåll, uppdelad - väg & & 94 & 92 & 88 \\
Vintervägsunderhåll & & 194 & 192 & 188 \\
Beläggningsunderhåll & & 46 & 44 & 43 \\
Grusvägsunderhåll & & 22 & 25 & 30 \\
Bro- och tunnelunderhåll & & 33 & 27 & 27 \\
Vägutrustning & & 23 & 23 & 25 \\
Färjedrift & & & & \\
\hline
\end{tabular}

\section{Planeringsram Sverige}

\begin{tabular}{|c|c|c|c|c|}
\hline \multirow[t]{2}{*}{ Sverige } & & \multicolumn{3}{|c|}{ Planeringsram } \\
\hline & & 2003 & 2004 & 2012 \\
\hline Ârlig volym investering & $\mathrm{M} €$ & & & \\
\hline Järnväg (statliga) & & 598 & 893 & 788 \\
\hline Väg (statliga) & & 1083 & 720 & 795 \\
\hline Årlig volym drift och underhåll & $M €$ & & & \\
\hline Järnväg (statliga) & & 489 & 504 & 431 \\
\hline Väg (statliga) & & 808 & 810 & 845 \\
\hline Drift och underhåll, uppdelad - väg & $M €$ & & & \\
\hline Vintervägsunderhåll & & 204 & 215 & - \\
\hline Beläggningsunderhåll & & 339 & 317 & - \\
\hline Grusvägsunderhåll & & 49 & 45 & - \\
\hline Bro- och tunnelunderhåll & & 77 & 75 & - \\
\hline Vägutrustning & & 93 & 110 & - \\
\hline Färjedrift & & 45 & 48 & - \\
\hline
\end{tabular}





\section{Bilaga 3}

Figur: Nordisk jämförelse av privata entreprenörer avseende omsättning 2002 (Källa: Veidekke).

\section{De største entreprenørbedriftene}

Omsetning 2002
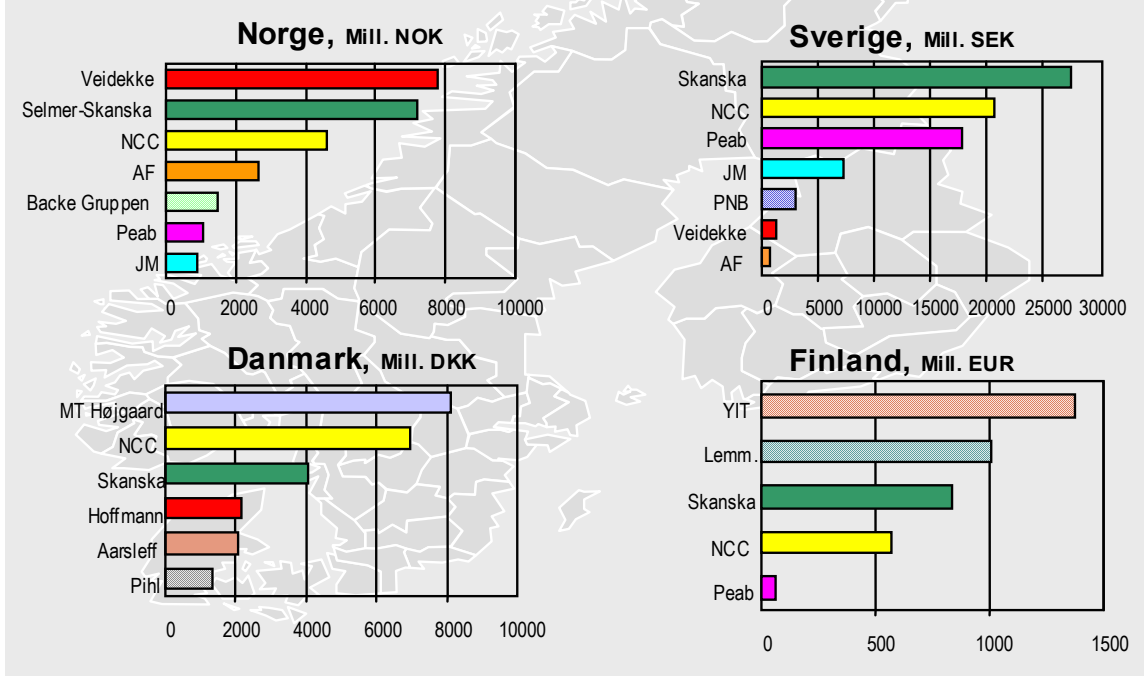
Figur: Översiktlig jämförelse av omsättningen 2003 för de statliga produktionsverksamheter inom väghållningen i respektive nordiskt land.

\section{Statlig producentverksamhet - väghållning} Omsättning 2003

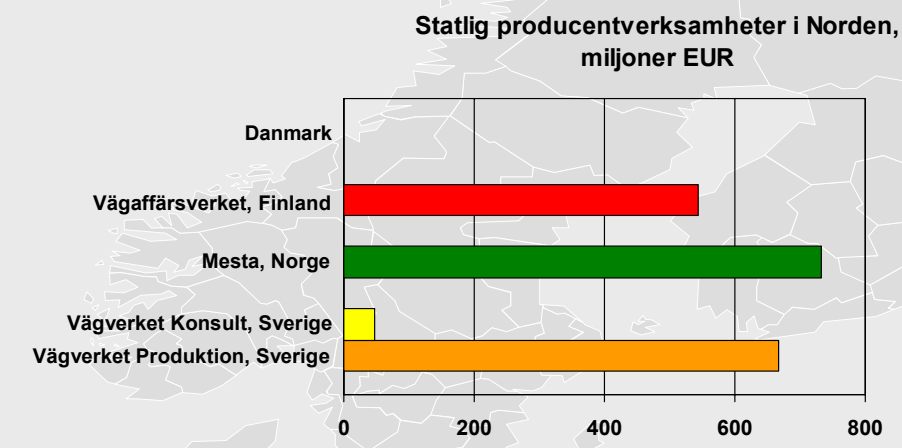

$1 \mathrm{EUR}=7,43 \mathrm{DKK}=8,20 \mathrm{NOK}=8,95 \mathrm{SEK}$ 


\section{Bilaga 4}

Tabell: Sammanställning av förslag på utvecklingsprojekt, framtagna av nordisk projektgrupp.

\begin{tabular}{|c|c|c|c|c|}
\hline $\begin{array}{c}\text { UTVECKLINGS- } \\
\text { PROJEKT } \\
\end{array}$ & $\begin{array}{c}\text { PROBLEM- } \\
\text { BESKRIVNING }\end{array}$ & $\begin{array}{c}\text { PÅGÅENDE } \\
\text { AKTIVITETER }\end{array}$ & $\begin{array}{c}\text { ANSVARIG } \\
\text { (NIVA) }\end{array}$ & ÅTGÄRD \\
\hline \multicolumn{5}{|l|}{$\begin{array}{l}\text { MARKNADS- } \\
\text { PLATS }\end{array}$} \\
\hline $\begin{array}{l}\text { Gemensam databas } \\
\text { för anslag och } \\
\text { planer }\end{array}$ & $\begin{array}{l}\text { Ryckighet i besluten } \\
\text { avseende anslagen } \\
\text { till trafikverken, } \\
\text { marknaden kan lätt } \\
\text { bli överhettad. } \\
\text { Förfrågningsunder- } \\
\text { lag för större och } \\
\text { mindre projekt går } \\
\text { ut till intressenter } \\
\text { via olika medier i } \\
\text { respektive land, bör } \\
\text { kunna samordnas } \\
\text { gemensamt. } \\
\text { En bättre informa- } \\
\text { tion till leverantö- } \\
\text { rerna beträffande } \\
\text { beställarnas utveck- } \\
\text { lingsåtgärder och } \\
\text { framtidsutsikter. }\end{array}$ & & Myndighet & $\begin{array}{l}\text { Verka för en } \\
\text { gemensam } \\
\text { nordisk data- } \\
\text { bas. Komple- } \\
\text { ment till TED } \\
\text { databasen. } \\
\text { BV/VV upp- } \\
\text { rättar gemen- } \\
\text { samt en data- } \\
\text { bas i norden } \\
\text { avseende } \\
\text { anslag och } \\
\text { planer. }\end{array}$ \\
\hline $\begin{array}{l}\text { Gemensam databas } \\
\text { för ordlista }\end{array}$ & $\begin{array}{l}\text { Språk- och defini- } \\
\text { tionsproblem är en } \\
\text { hög barriär i båda } \\
\text { riktningarna, dels } \\
\text { nationellt mellan } \\
\text { aktörer och dels } \\
\text { mellan de nordiska } \\
\text { länderna. }\end{array}$ & $\begin{array}{l}\text { NVF } 31 \text { arbetar med } \\
\text { frågan. Inom jvg- } \\
\text { området finns ord- } \\
\text { lista upprättad av } \\
\text { UIC. Finland har } \\
\text { startat ett nationellt } \\
\text { projekt - Infra-RYL }\end{array}$ & Myndighet & $\begin{array}{l}\text { Ta fram ge- } \\
\text { mensam ord- } \\
\text { lista för väg-, } \\
\text { gatu- och } \\
\text { banarbeten. } \\
\text { Främst inom } \\
\text { områden som } \\
\text { ingår i förfråg- } \\
\text { ningsunder- } \\
\text { lagen. }\end{array}$ \\
\hline \multicolumn{5}{|l|}{$\begin{array}{l}\text { FÖRESKRIFTER } \\
\text { OCH BESTÄM- } \\
\text { MELSER } \\
\end{array}$} \\
\hline $\begin{array}{l}\text { Tekniska beskriv- } \\
\text { ningar }\end{array}$ & $\begin{array}{l}\text { Skillnader i de } \\
\text { kundspecifika } \\
\text { tekniska beskriv- } \\
\text { ningarna komplice- } \\
\text { rar arbetet över } \\
\text { gränserna. }\end{array}$ & & Myndighet & $\begin{array}{l}\text { Anpassa till } \\
\text { enhetliga } \\
\text { nordiska } \\
\text { tekniska } \\
\text { regelverk. }\end{array}$ \\
\hline
\end{tabular}




\begin{tabular}{|l|l|l|l|l|}
\hline $\begin{array}{l}\text { Allmänna avtals- } \\
\text { villkor }\end{array}$ & $\begin{array}{l}\text { Skillnader om än } \\
\text { små föreligger } \\
\text { mellan Sveriges } \\
\text { AB92 och ABT94, } \\
\text { Norges NS 34:30, } \\
\text { NS 34:31 samt } \\
\text { Finlands YSE 98. }\end{array}$ & & Branschen & Utveckla en \\
& & & \\
& & & \\
\hline
\end{tabular}

\begin{tabular}{|c|c|c|c|c|}
\hline $\begin{array}{l}\text { UTVECKLINGS- } \\
\text { PROJEKT } \\
\end{array}$ & $\begin{array}{c}\text { PROBLEM } \\
\text { BESKRIVNING } \\
\end{array}$ & $\begin{array}{c}\text { PÅGÅENDE } \\
\text { AKTIVITETER } \\
\end{array}$ & $\begin{array}{c}\text { ANSVARIG } \\
\text { (NIVÃ) } \\
\end{array}$ & ÅTGÄRD \\
\hline Kvalitetskrav & $\begin{array}{l}\text { Beställaren förutsät- } \\
\text { ter förutom att do- } \\
\text { kumenterade krav } \\
\text { efterföljs att även } \\
\text { outtalade krav enligt } \\
\text { gällande praxis } \\
\text { efterföljs. }\end{array}$ & $\begin{array}{l}\text { Finland har startat } \\
\text { ett nationellt } \\
\text { projekt - Infra- } \\
\text { byggnads- } \\
\text { branschens all- } \\
\text { männa kvalitets- } \\
\text { krav (Infra-RYL) }\end{array}$ & Myndighet & $\begin{array}{l}\text { Kvalitetskraven } \\
\text { bör enhetligas } \\
\text { inom Norden }\end{array}$ \\
\hline Produktstandarder & $\begin{array}{l}\text { Inga enhetliga stan- } \\
\text { dardarder förekom- } \\
\text { mer mellan länderna } \\
\text { - irrationellt. }\end{array}$ & & Branschen & $\begin{array}{l}\text { Etablera ge- } \\
\text { mensamma } \\
\text { normer för } \\
\text { produkter. }\end{array}$ \\
\hline $\begin{array}{l}\text { Tvister och me- } \\
\text { ningsskiljaktigheter }\end{array}$ & $\begin{array}{l}\text { Skillnader förekom- } \\
\text { mer mellan länderna } \\
\text { kring hur man hante- } \\
\text { rar meningsskiljak- } \\
\text { tigheter. }\end{array}$ & & Branschen & $\begin{array}{l}\text { Systematisera } \\
\text { handläggningen } \\
\text { av tvisterna. }\end{array}$ \\
\hline $\begin{array}{l}\text { Tolkning av EU- } \\
\text { regler }\end{array}$ & $\begin{array}{l}\text { Med en enhetlig } \\
\text { målsättning kan man } \\
\text { tillsammans bättre } \\
\text { påverka lagar och } \\
\text { direktiv inom EU. }\end{array}$ & & Myndighet & $\begin{array}{l}\text { Etablera ge- } \\
\text { mensamma } \\
\text { nätverk avseen- } \\
\text { de tolkning av } \\
\text { Eu-regler } \\
\end{array}$ \\
\hline Jävsfrågor & $\begin{array}{l}\text { Otydliga spelregler } \\
\text { avseende hantering } \\
\text { av jävighetsfrågor i } \\
\text { de nordiska länderna } \\
\text { vid köp av t.ex. } \\
\text { konsulttjänster. }\end{array}$ & & Branschen & $\begin{array}{l}\text { Tydliggöra } \\
\text { spelreglerna. }\end{array}$ \\
\hline $\begin{array}{l}\text { Hälsa, miljö och } \\
\text { säkerhet (HMS) }\end{array}$ & $\begin{array}{l}\text { Allvarliga } \\
\text { arbetsolyckor medför } \\
\text { sociala och ekono- } \\
\text { miska förluster, för- } \\
\text { svagar branschens } \\
\text { image och minskar } \\
\text { de ungas intresse för } \\
\text { branschen. }\end{array}$ & & $\begin{array}{l}\text { Departe- } \\
\text { ment/Myndi } \\
\text { ghet/ } \\
\text { Bransch }\end{array}$ & $\begin{array}{l}\text { Enhetliga } \\
\text { HMS- } \\
\text { bestämmelser } \\
\text { inom Norden. }\end{array}$ \\
\hline
\end{tabular}




\begin{tabular}{|l|l|l|l|l|}
\hline $\begin{array}{l}\text { Tillstånd för } \\
\text { entrepre- } \\
\text { nadmaskiner }\end{array}$ & $\begin{array}{l}\text { Byråkratiska svårig- } \\
\text { heter att få arbetsma- } \\
\text { skiner över gränser- } \\
\text { na. }\end{array}$ & Myndighet & $\begin{array}{l}\text { Gemensamma } \\
\text { regler för god- } \\
\text { kännande av } \\
\text { spårtekniska } \\
\text { och säkerhets- } \\
\text { mässiga krav på } \\
\text { maskiner vid } \\
\text { järnvägsbyg- } \\
\text { gande. }\end{array}$ \\
\hline $\begin{array}{l}\text { Obligatoriska kurser } \\
\text { och utbildningar }\end{array}$ & $\begin{array}{l}\text { Samma typer av } \\
\text { skolningssystem, } \\
\text { t.ex. "Arbete på väg", } \\
\text { är inte godkänd i } \\
\text { grannländerna. }\end{array}$ & Branschen & $\begin{array}{l}\text { Organisering av } \\
\text { neutrala skol- } \\
\text { ningssystem. }\end{array}$ \\
\hline
\end{tabular}

\begin{tabular}{|c|c|c|c|c|}
\hline $\begin{array}{c}\text { UTVECKLINGS- } \\
\text { PROJEKT } \\
\end{array}$ & $\begin{array}{c}\text { PROBLEM } \\
\text { BESKRIVNING } \\
\end{array}$ & $\begin{array}{c}\text { PÅGÅENDE } \\
\text { AKTIVITETER } \\
\end{array}$ & $\begin{array}{c}\text { ANSVARIG } \\
\text { (NIVÅ) }\end{array}$ & ÅTGÄRD \\
\hline \multicolumn{5}{|l|}{$\begin{array}{l}\text { UPPHANDLINGS- } \\
\text { PROCESSEN }\end{array}$} \\
\hline $\begin{array}{l}\text { Nordisk leveran- } \\
\text { törsmarknadsvision }\end{array}$ & $\begin{array}{l}\text { Främja nordisk } \\
\text { leverantörsmarknad. }\end{array}$ & & Myndighet & $\begin{array}{l}\text { Verka för en } \\
\text { gemensam } \\
\text { anläggnings- } \\
\text { marknad. }\end{array}$ \\
\hline $\begin{array}{l}\text { Likformade anbuds- } \\
\text { och kontraktformu- } \\
\text { lär }\end{array}$ & $\begin{array}{l}\text { Framtagande av } \\
\text { enhetliga anbuds- } \\
\text { och avtalsformulär } \\
\text { borde främjas om } \\
\text { man vill upnå en } \\
\text { gemensam nordisk } \\
\text { upphandlingsmark- } \\
\text { nad. }\end{array}$ & & Branschen & $\begin{array}{l}\text { Utveckla enhet- } \\
\text { liga elektronis- } \\
\text { ka anbuds- och } \\
\text { avtalsformulär. }\end{array}$ \\
\hline $\begin{array}{l}\text { Entreprenadformer } \\
\text { för innovativa } \\
\text { lösningar }\end{array}$ & $\begin{array}{l}\text { I de nordiska länder- } \\
\text { na finns likheter och } \\
\text { skillnader avseende } \\
\text { entreprenadformer. }\end{array}$ & & Branschen & $\begin{array}{l}\text { Entreprenad- } \\
\text { former för } \\
\text { innovativa } \\
\text { lösningar }\end{array}$ \\
\hline $\begin{array}{l}\text { Elektronisk anbuds- } \\
\text { hantering }\end{array}$ & $\begin{array}{l}\text { Nyttjande av infor- } \\
\text { mation- och kom- } \\
\text { munikationstekniskt } \\
\text { kunnande. }\end{array}$ & & Myndighet & $\begin{array}{l}\text { Framtagande av } \\
\text { elektronisk } \\
\text { anbudshanter- } \\
\text { ing. }\end{array}$ \\
\hline $\begin{array}{l}\text { Gemensam upp- } \\
\text { handlingsutbildning }\end{array}$ & $\begin{array}{l}\text { Erfarenhetsutbyte } \\
\text { mellan beställare i } \\
\text { norden efterfrågas. }\end{array}$ & & Myndighet & $\begin{array}{l}\text { Gemensam } \\
\text { utbildning/ } \\
\text { rotation/ Trai- } \\
\text { nee. }\end{array}$ \\
\hline
\end{tabular}




\begin{tabular}{|l|l|l|l|l|}
\hline $\begin{array}{l}\text { SAMARBETS- } \\
\text { FORMER }\end{array}$ & & Branschen & $\begin{array}{l}\text { Modeller för } \\
\text { spelregler } \\
\text { avseende } \\
\text { samarbetsavtal } \\
\text { och risktagning } \\
\text { upprättas. }\end{array}$ \\
\hline $\begin{array}{l}\text { Modeller för spel- } \\
\text { regler avseende } \\
\text { samarbetsavtal och } \\
\text { risktagning. }\end{array}$ & $\begin{array}{l}\text { Förutsättningar } \\
\text { skapas för att arbeta } \\
\text { mot gemensamma } \\
\text { mål där ett delat } \\
\text { ansvar bör öka } \\
\text { engagemanget. }\end{array}$ & & Branschen & $\begin{array}{l}\text { Utveckling av } \\
\text { funktionskrav } \\
\text { som ett nordiskt } \\
\text { samarbete. }\end{array}$ \\
\hline $\begin{array}{l}\text { Gemensamma } \\
\text { funktionskrav }\end{array}$ & $\begin{array}{l}\text { Ett sätt att undvika } \\
\text { onödiga låsningar i } \\
\text { utformningen av } \\
\text { anläggningen i tidiga } \\
\text { skeden är att arbeta } \\
\text { med funktionskrav. }\end{array}$ & & Myndighet & $\begin{array}{l}\text { Utveckla nät- } \\
\text { verk för erfa- } \\
\text { renhetsutbyte. }\end{array}$ \\
\hline $\begin{array}{l}\text { Uppföljning av och } \\
\text { informations- } \\
\text { spridning om nya } \\
\text { samarbetsformer }\end{array}$ & $\begin{array}{l}\text { Ett större utbyte } \\
\text { borde ske mellan de } \\
\text { nordiska länderna } \\
\text { avseende spridning } \\
\text { och uppföljning av } \\
\text { nya samarbetsfor- } \\
\text { mer. }\end{array}$ & & & \\
\hline
\end{tabular}

\begin{tabular}{|c|c|c|c|c|}
\hline $\begin{array}{c}\text { UTVECKLINGS- } \\
\text { PROJEKT } \\
\end{array}$ & $\begin{array}{c}\text { PROBLEM- } \\
\text { BESKRIVNING }\end{array}$ & $\begin{array}{c}\text { PÅGÅENDE } \\
\text { AKTIVITETER } \\
\end{array}$ & $\begin{array}{c}\text { ANSVARIG } \\
\text { (NIVÅ) }\end{array}$ & ÅTGÄRD \\
\hline \multicolumn{5}{|l|}{ ÖVRIGT } \\
\hline $\begin{array}{l}\text { Översyn beskatt- } \\
\text { ningsregler }\end{array}$ & $\begin{array}{l}\text { Kostnadskrävande } \\
\text { beskattning på } \\
\text { arbetsmaskiner när } \\
\text { de tas över gränser- } \\
\text { na. }\end{array}$ & & Departement & $\begin{array}{l}\text { Ändring av } \\
\text { regler. }\end{array}$ \\
\hline $\begin{array}{l}\text { Översyn konkur- } \\
\text { renshämmande avtal }\end{array}$ & $\begin{array}{l}\text { Upprättande av } \\
\text { konkurrens- } \\
\text { hämmande avtal och } \\
\text { avgifter. Detta } \\
\text { gynnar inte möjlig- } \\
\text { heten för aktörer att } \\
\text { verka på en nordisk } \\
\text { marknad. }\end{array}$ & & Departement & $\begin{array}{l}\text { Ändring av } \\
\text { regler. }\end{array}$ \\
\hline $\begin{array}{l}\text { Gemensamt kompa- } \\
\text { tibelt IT-system }\end{array}$ & $\begin{array}{l}\text { Olika IT-system i de } \\
\text { olika länderna och } \\
\text { även inom länderna } \\
\text { förekommer skillna- } \\
\text { der. }\end{array}$ & $\begin{array}{l}\text { TEKES i Finland } \\
\text { har genomfört ett } \\
\text { framgångsrikt } \\
\text { projekt }\end{array}$ & Branschen & $\begin{array}{l}\text { Gemensamma } \\
\text { kompatibla } \\
\text { system. }\end{array}$ \\
\hline
\end{tabular}




\section{Nordisk Ministerråds og Nordisk Råds publikationer kan bestilles hos:}

\begin{tabular}{|c|}
\hline $\begin{array}{l}\text { BELGIEN \& LUXEMBOURG } \\
\text { Jean de Lannoy } \\
\text { Avenue du Roi, 202, } 1190 \text { Brussels } \\
\text { Tel +32 (0)2 } 5385169 \text { Fax +32 (0)2 } 538 \\
0841 \\
\text { jean.de.lannoy@euronet.be }\end{array}$ \\
\hline $\begin{array}{l}\text { CANADA } \\
\text { Renouf Publishing Company Ltd } \\
5369 \text { Canotek Road, Ottawa, } \\
\text { Ontario K1J 9J3 } \\
\text { Tel + } 1 \text { (613) } 7452665 \\
\text { Fax + } 1 \text { (613) } 7457660 \\
\text { order.dept@renoufbooks.com } \\
\text { www.renoufbooks.com }\end{array}$ \\
\hline $\begin{array}{l}\text { DANMARK } \\
\text { Svensk-Norsk Bogimport A/S } \\
\text { Esplanaden } 8 \text { B, 1263 København K } \\
\text { Tel +45 } 33142666 \text { Fax +4533143588 } \\
\text { snb@bog.dk } \\
\text { www.snbog.dk }\end{array}$ \\
\hline $\begin{array}{l}\text { ESTLAND } \\
\text { Astro Raamatud AS } \\
\text { Pärnu mnt 142, 11317 Tallinn } \\
\text { Tel +372 654 8485 Fax +372 } 6548475 \\
\text { book@astro.ee }\end{array}$ \\
\hline $\begin{array}{l}\text { FINLAND } \\
\text { Akademiska Bokhandeln } \\
\text { PB 128, Centralgatan 1, } 00101 \text { Helsingfors } \\
\text { Tel +358 } 912141 \\
\text { akatilaus@akateeminen.com } \\
\text { www.akateeminen.com }\end{array}$ \\
\hline $\begin{array}{l}\text { FRANKRIG } \\
\text { Librairie LAVOISIER } \\
\text { 14, rue de Provigny, } 94236 \text { Cachan Cedex } \\
\text { Tel +33 (1) } 47406700 \text { Fax +33 (1) } 4740 \\
6702 \\
\text { group@lavoisier.fr } \\
\text { www.lavoisier.fr }\end{array}$ \\
\hline $\begin{array}{l}\text { F/ERøERNE } \\
\text { H.N. Jacobsens Bókahandil } \\
\text { Postboks 55, } 110 \text { Tórshavn } \\
\text { Tel +298 } 311036 \text { Fax +298 } 317873\end{array}$ \\
\hline
\end{tabular}

hnj@hnj.fo

www.hnj.fo

De Lindeboom Internationale Publicaties b.v.

M.A. de Ruyterstraat $20 \mathrm{~A}$

$\mathrm{NL}-7482 \mathrm{BZ}$ Haaksbergen

Tel +31 (0)535740004

Fax +31 (0)53 5729296

books@delindeboom.com

www.delindeboom.com

\section{ISLAND}

Mál og Menning

Laugavegi 18, 101 Reykjavik

Tel +354 (9)5152500

Fax +354 (9)515 2505

verslun@mm.is

books@penninn.is

KINA

C N P I E C, Europe Division

16 Gongti East Road

P.O. Box 88, Beijing

Tel +86 $105066688-8$

Fax +86 105063101

\section{LETLAND}

Jana Rozes Gramàtnica

Kr. Barona iela 5, 1011 Riga

Tel +371 (0)2 284288 Fax +3717370922

\section{LITAUEN}

Penki Kontinentai

A. Stulginskio 5, 2001 Vilnius

Tel +370 (5) 2664540 Fax +370 (5) 2664565

books@5ci.lt

www.books.It

\section{NORGE}

Akademika A/S

Postboks 84 Blindern, 0314 Oslo

Tel +4722853030 Fax +4722853080

bloken@sio.uio.no

www.akademika.no

RUMFENIEN

Euromedia s.r.l.

Str Dionisie Lupu nr 65, 70184 Bucuresti
Tel + 4016140664 Fax +4013129646

\section{STORBRITANNIEN}

The Stationery Office

P.O. Box 276, London SW8 5DT

Tel +44870600 5522 Fax +44 8706005533

customer.services@tso.co.uk

www.tso.co.uk/bookshop

\section{SVERIGE}

Kundservice, 10647 Stockholm

Tel +46 (0)8 6909190

Fax +46 (0)8 6909191

order.fritzes@nj.se

www.fritzes.se

\section{TYSKLAND}

UNO-Verlag GmbH

Am Hofgarten 10, 53113 Bonn

Tel +49 (0)228 949020

Fax +49 (0)228 9490222

info@uno-verlag.de

www.uno-verlag.de

UNGARN

Euro Info Service

PO Box 1039, 1245 Budapest

Tel +36 (1) 3292487 Fax +36 (1) 3492053 euroinfo@euroinfo.hu

USA

Bernan

4611-F Assembly Drive

Lanham MD 20706-4391

Tel +1 (301) 4597666

Fax +1 (301) 4590056

query@bernan.com

www.bernan.com

\section{ÅLAND}

Lisco bok- och pappershande

Skarpansvägen 25, Box 8

22101 Mariehamn

Tel +358 (0)1817 177

Fax +358 (0)18 19771

info@lisco.fi 